FINAL REPORT

FHWA/IN/JTRP-2001/28

\title{
GUIDELINES FOR USE AND TYPES OF RETAINING DEVICES
}

\author{
By \\ Antonio Bobet \\ Assistant Professor \\ School of Civil Engineering \\ Purdue University \\ Joint Highway Research Program \\ Project No. C-36-36JJ \\ File No. 6-14-36 \\ SPR-2466 \\ Prepared in Cooperation with the \\ Indiana Department of Transportation \\ and the \\ U.S. Department of Transportation \\ Federal Highway Administration
}

The contents of this report reflect the views of the authors who are responsible for the facts and the accuracy of the data presented herein. The contents do not necessarily reflect the official views or policies of the Federal Highway Administration and the Indiana Department of Transportation. The report does not constitute a standard, specification, or regulation.

Purdue University

West Lafayette, IN 47907

April 2002 


\begin{tabular}{|c|c|c|}
\hline $\begin{array}{l}\text { 1. Report No. } \\
\text { FHWA/IN/JTRP-2001/28 }\end{array}$ & 2. Government Accession No. & 3. Recipient's Catalog No. \\
\hline \multirow{2}{*}{\multicolumn{2}{|c|}{$\begin{array}{l}\text { 4. Title and Subtitle } \\
\text { Guidelines for Use and Types of Retaining Devices }\end{array}$}} & $\begin{array}{l}\text { 5. } \quad \text { Report Date } \\
\text { April } 2002\end{array}$ \\
\hline & & 6. Performing Organization Code \\
\hline \multicolumn{2}{|l|}{$\begin{array}{l}\text { 7. Author(s) } \\
\text { Antonio Bobet }\end{array}$} & $\begin{array}{l}\text { 8. Performing Organization Report No. } \\
\text { FHWA/IN/JTRP-2001/28 }\end{array}$ \\
\hline \multirow{2}{*}{\multicolumn{2}{|c|}{$\begin{array}{l}\text { 9. Performing Organization Name and Address } \\
\text { Joint Transportation Research Program } \\
1284 \text { Civil Engineering Building } \\
\text { Purdue University } \\
\text { West Lafayette, IN 47907-1284 }\end{array}$}} & 10. Work Unit No. \\
\hline & & $\begin{array}{l}\text { 11. Contract or Grant No. } \\
\text { SPR-2466 }\end{array}$ \\
\hline \multirow{2}{*}{\multicolumn{2}{|c|}{$\begin{array}{l}\text { 12. Sponsoring Agency Name and Address } \\
\text { Indiana Department of Transportation } \\
\text { State Office Building } \\
100 \text { North Senate Avenue } \\
\text { Indianapolis. IN } 46204\end{array}$}} & $\begin{array}{c}\text { 13. Type of Report and Period Covered } \\
\text { Final Report }\end{array}$ \\
\hline & & 14. Sponsoring Agency Code \\
\hline \multicolumn{3}{|l|}{ 15. Supplementary Notes } \\
\hline
\end{tabular}

\section{Abstract}

A large number of types of retaining devices are currently available but their limitations, recommendations and guidelines are scattered in the technical literature. A synthesis study has been made in which different technologies have been investigated to develop guidelines for the use of the different types of retaining devices. For this purpose, an extensive literature review has been performed and a new classification has been proposed.

An electronic database with 207 selected cases from the technical literature and INDOT archives has been created. The database stores the following information: (1) Type of Retaining Device; (2) Geometry (3) Soil conditions; (4) Experience and Performance; (5)

Construction; (6) Durability; (7) Economy; and (8) Special considerations.

The information stored has been analyzed through a number of correlations. Two design flowcharts have been developed to identify the most cost-effective solutions based on the height of the wall, cost, and soil conditions: one for Fill Walls, and another one for Cut Walls. The conclusions and recommendations obtained are in agreement with guidelines from the Federal Highway Administration (FHWA), and with specifications from the Indiana Department of Transportation. The following is recommended for implementation: (1) Use the flowcharts developed as a preliminary decision-making tool to decide the optimum type of wall for a given project; and (2) the recommendations are based on up-to-date information. It is expected that with time design trends and wall typologies may become obsolete and new technologies may become available. It is recommended that the database and flowcharts be updated every five years. The flowcharts and additional notes provide general recommendations based on limited information. The flowcharts are not intended to cover all possible cases; they should be used for preliminary design and to facilitate engineering decisions. Site-specific conditions or project constraints may require a different solution than that provided by the charts.

\section{Key Words}

Retaining structures, wall typologies, wall design, fill walls, cut walls, electronic database

\section{Distribution Statement}

No restrictions. This document is available to the public through the National Technical Information Service, Springfield, VA 22161
19. Security Classif. (of this report)

Unclassified

\author{
20. Security Classif. (of this page)
}

Unclassified

21. No. of Pages
144

22. Price 


\section{TECHNICAL Summary}

Technology Transfer and Project Implementation Information

\section{Guidelines for Use and Types of Retaining Devices}

\section{Introduction}

A large number of types of retaining devices can be used for design, but their limitations, recommendations and guidelines are scattered in the technical literature. A synthesis study has been conducted in which different technologies have been investigated to develop guidelines for the use of the different types of retaining devices. For this purpose, an extensive literature review has been performed and a new classification has been proposed. Retaining devices are divided into fill and cut walls. Fill walls support a backfill while cut walls support the natural ground. Fill walls are subdivided in: (1) Rigid and Cantilever Gravity Walls (RCGW); (2) Flexible Gravity Walls (FGW); and (3) Mechanically Stabilized Earth (MSE) Walls. Cut walls are subdivided in: (1) Driven walls (DW); (2) Cast in-place Walls (CIPW); and (3) Soil Nailed Walls (SNW).

Databases that collect a large number of case histories can be used as decision- making tools. The information stored can be utilized for: (1) development of correlations and trends among the cases in the database; (2) comparison of a new wall design with the case histories in the database to determine similarities and differences between the projects.

An electronic database with 207 selected cases from the technical literature and INDOT archives has been created. The database stores the following information: (1) Type of Retaining Device, location; (2) Geometry: Dimensions (height, length, etc.); (3) Soil conditions: Foundation, backfill; (4) Experience and Performance (Service: Deformations during and after construction); (5) Construction: Material used, construction process, problems; (6) Durability: Maintenance records, type and cost; (7) Economy: Construction and maintenance costs; (8) Other issues: special considerations, noise levels,

etc.

\section{Findings}

The information stored has been analyzed through a number of correlations. The following conclusions have been obtained:

(1) The most cost-effective type of wall for a given project depends on the height of the wall and on the soil conditions.

(2) For fill walls:

(a) Mechanically Stabilized Earth (MSE) Walls can tolerate large differential settlements; Flexible
Gravity Walls (FGW) can tolerate differential settlements up to $1 / 50$; and. Rigid and Cantilever Gravity Walls (RCGW) can only tolerate differential settlements up to $1 / 500$.

(b) The use of a fine-grained backfill without pore pressure considerations typically leads to failure of the wall. Freezing and thawing also leads to long-term progressive failure in a cohesive backfill. 
(c) Corrosion of galvanized metallic elements is usually not significant.

(d) Compaction of the backfill around the connection of the reinforcement of MSE walls is usually reported as a problem.

(e) Large differential settlements in MSE walls can cause damage to the facing elements.

(f) MSE walls are the most economic fill retaining devices. If MSE walls cannot be used, Concrete and Masonry walls are the most cost effective devices for heights smaller than three meters. For larger heights, FGW are typically used.

(g) A flowchart has been developed to identify the most cost-effective solution based on the height of the wall, cost, and soil conditions.
(3) For cut walls:

(a) Driven Walls (DW) and Cast inplace Walls (CIPW) above five meters require additional support systems.

(b) Additional settlements can occur in DW during construction if the time between excavation and placement of the lagging is too large.

(c) CIPW limit the ground settlements behind the wall.

(d) Soil nails have had a limited use because of lack of experience with their design and construction. They are not used in soils without sufficient frictional resistance, which is necessary to provide stability to the un-reinforced section of the wall immediately after excavation.

\section{Implementation}

The following is recommended for implementation:

(1) Use the flowcharts developed as a preliminary decision-making tool to decide the optimum type of wall for a given project.

(2) The flowcharts and additional notes provide general recommendations based on limited information. The flowcharts are not intended to cover all possible cases; they should be used for preliminary design and to facilitate engineering decision. Site-specific conditions or project constraints may require a different solution than that provided by the charts.

(3) The recommendations are based on up-to-date information. It is expected that with time design the trends and wall typologies identified in this study may become obsolete and new technologies may emerge. It is recommended that the database and flowcharts be updated every five years.

\section{Contacts}

For more information:

Prof. Antonio Bobet

Principal Investigator

School of Civil Engineering

Purdue University

West Lafayette IN 47907

Phone: (765) 4945033

Fax: (765) 496-1364
Indiana Department of Transportation

Division of Research

1205 Montgomery Street

P.O. Box 2279

West Lafayette, IN 47906

Phone: (765) 463-1521

Fax: (765) 497-1665

\section{Purdue University}

Joint Transportation Research Program

School of Civil Engineering

West Lafayette, IN 47907-1284 
Phone: (765) 494-9310

Fax: (765) 496-1105 
TABLE OF CONTENTS

Page

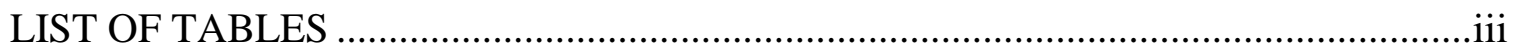

LIST OF FIGURES ...................................................................................................

IMPLEMENTATION REPORT .............................................................................. vi

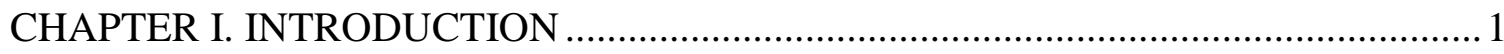

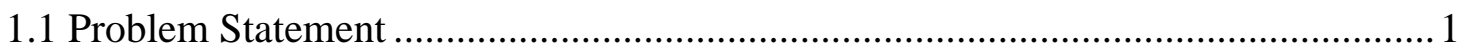

1.2 Scope of Study ................................................................................................ 2

1.3 Anticipated Implementation and Benefits of the Study .................................... 3

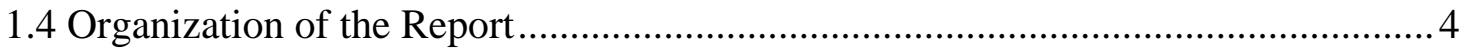

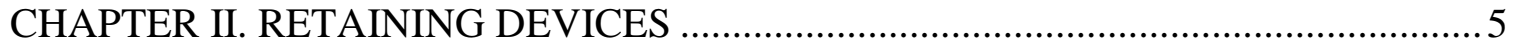

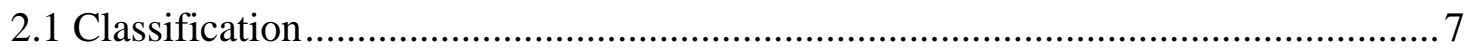

2.2 Externally Stabilized Systems .................................................................... 9

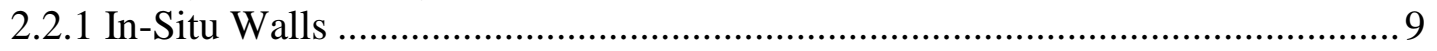

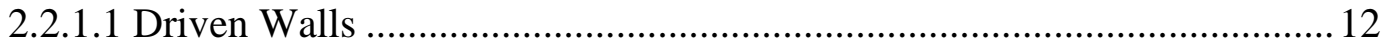

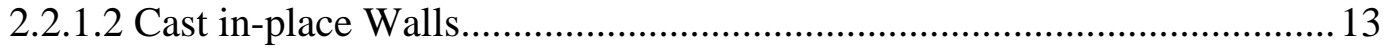

2.2.1.3 Additional Support ............................................................................. 14

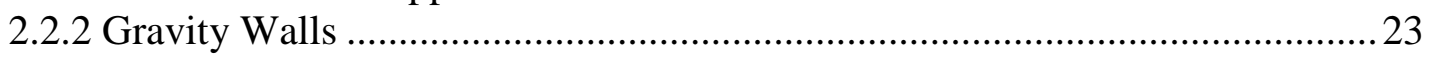

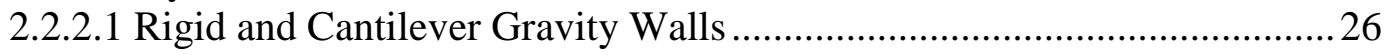

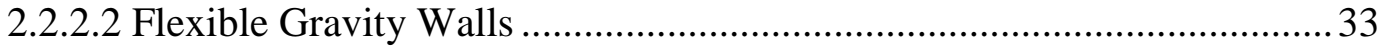

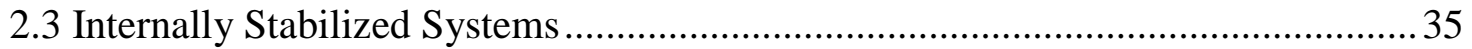

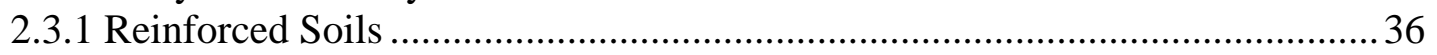

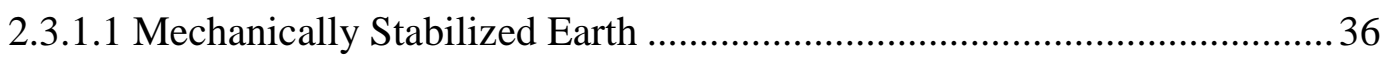

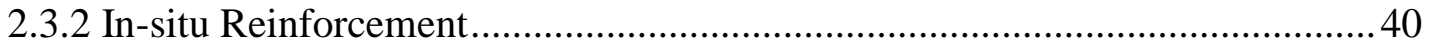

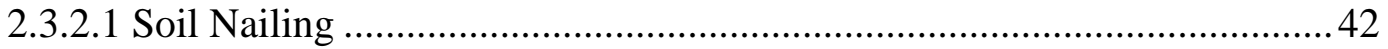

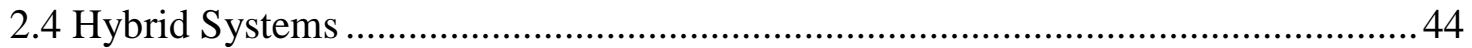

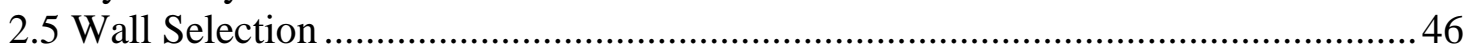

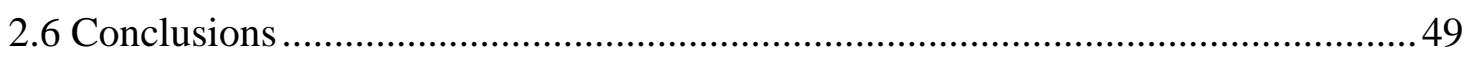

CHAPTER III. DATABASE OF RETAINING DEVICES ........................................ 51

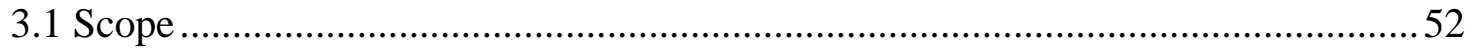

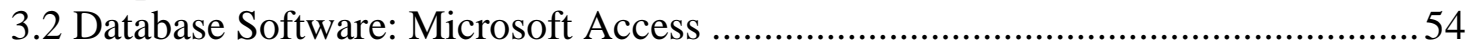

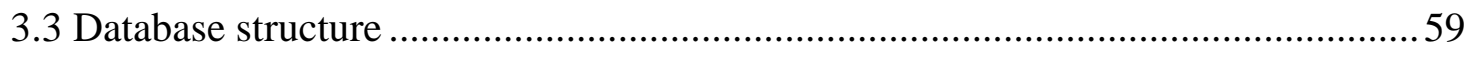




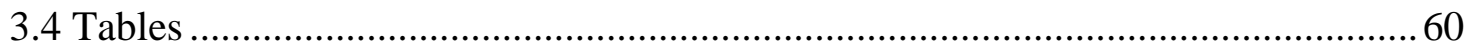

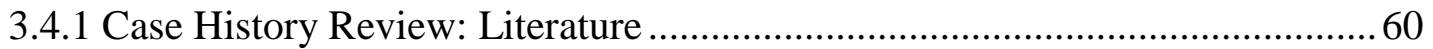

3.4.2 Case History Review: INDOT's Database ....................................................

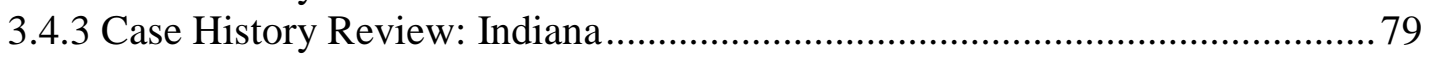

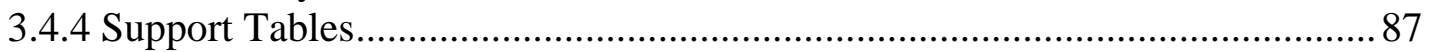

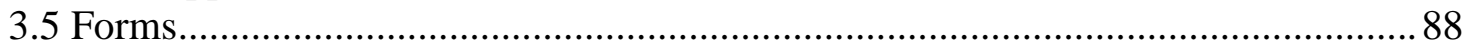

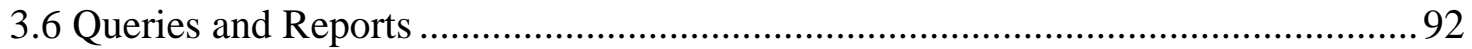

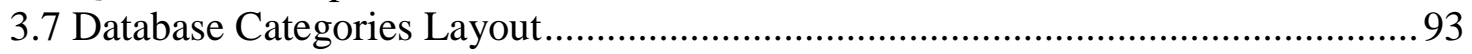

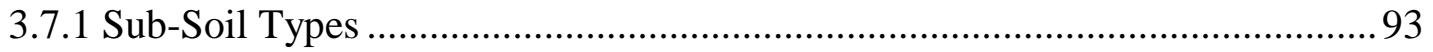

3.7.2 Retaining Device Type ............................................................................99

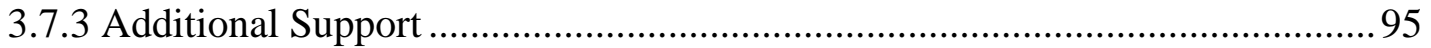

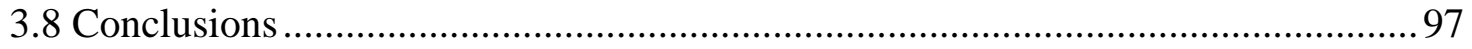

CHAPTER IV. SELECTION OF RETAINING DEVICES ..........................................98

4.1 Federal Highway Administration recommendations ............................................98

4.1.1 Rigid and Cantilever Gravity Walls ................................................................... 103

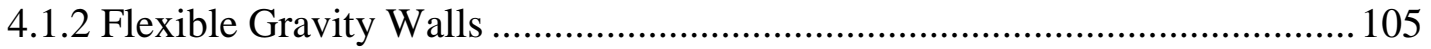

4.1.3 Mechanically Stabilized Earth Walls .............................................................. 107

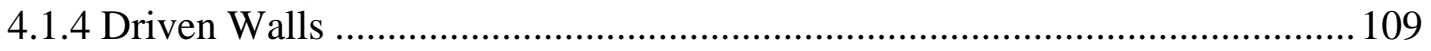

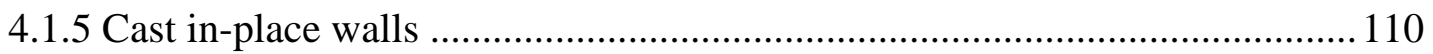

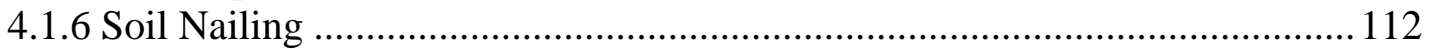

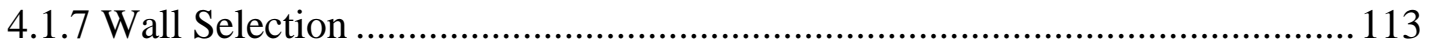

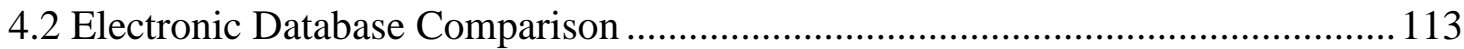

4.2.1 Indiana Department of Transportation specifications .................................... 114

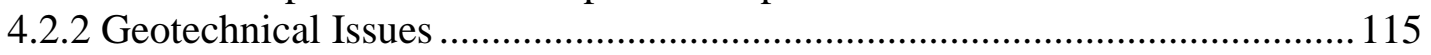

4.2.3 Experience and Performance Issues ......................................................... 122

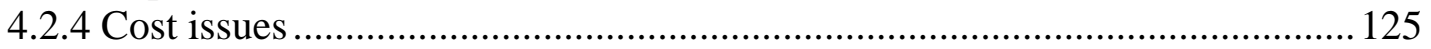

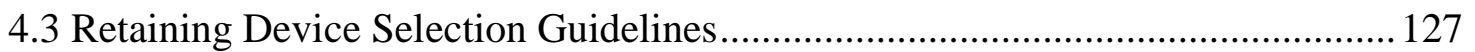

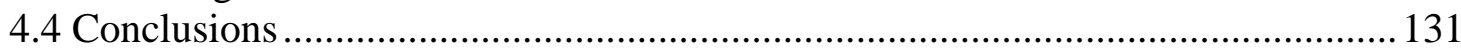

CHAPTER V. CONCLUSIONS AND RECOMMENDATIONS ..................................134

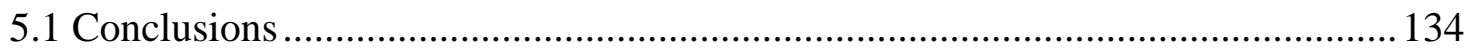

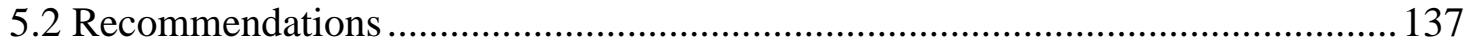

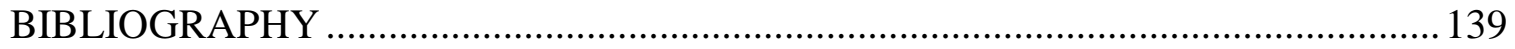




\section{LIST OF TABLES}

Table Page

3.1 Field Description of Case History Review: Literature .................................... 61

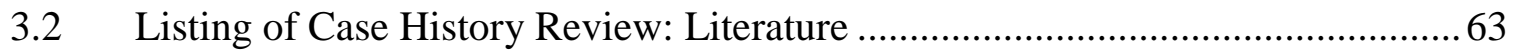

3.3 Field Description of Case History Review: INDOT Database .......................... 72

3.4 Listing of Case History Review: INDOT Database ........................................ 73

3.5 Field Description of Case History Review: Indiana.................................... 81

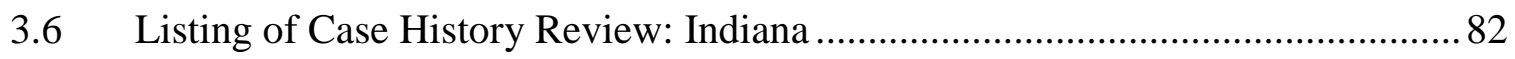

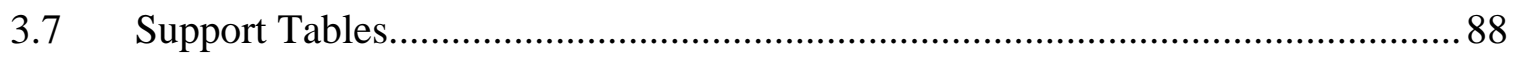

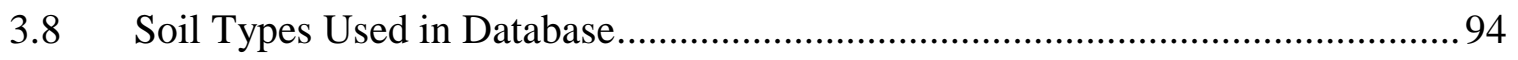

3.9 Retaining Device Types Used on Database ............................................. 96

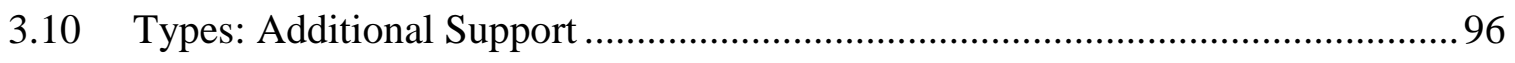

4.1 Retaining device selection chart for fill walls (FHWA, 1995) .......................... 99

4.2 Retaining device selection chart for cut walls (FHWA, 1995) .......................... 100

4.3 Fill retaining device advantages and disadvantages (FHWA, 1995) ................. 101

4.4 Cut retaining device advantages and disadvantages (FHWA, 1995) .................. 102

4.5 Average Height of Database Fill retaining devices...................................... 118

4.6 Average Height of Database Cut retaining devices ...................................... 119

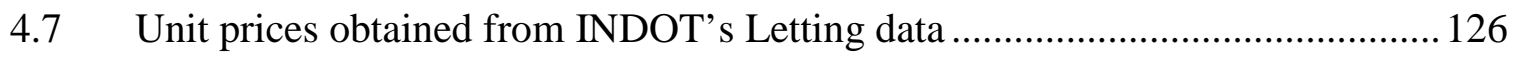

4.8 Estimated unit prices per meter square of wall based on complete database...... 126 


\section{LIST OF FIGURES}

$\begin{array}{ll}\text { Figure } & \text { Page }\end{array}$

2.1 O’ Rourke and Jones (1990) Retaining Devices Classification ........................... 8

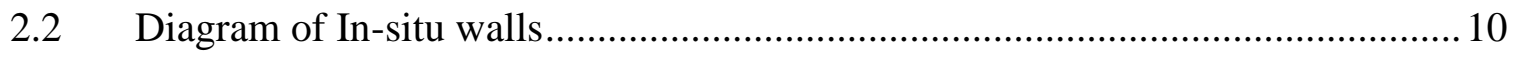

2.3 Diagram of a Braced excavation (after Das, 1990) ......................................... 15

2.4 Peck's (1969) apparent pressure envelope for cuts in sand (after Das, 1999) ...... 16

2.5 Peck's (1969) apparent pressure envelope for cuts in soft to medium clay

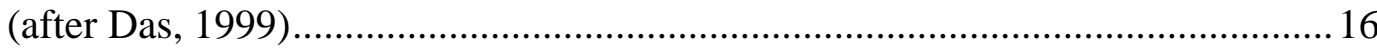

2.6 Peck's (1969) apparent pressure envelope for cuts in stiff clay (after

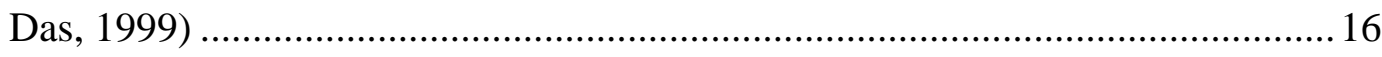

2.7 Range of variation of $\delta \mathrm{H}(\max ) / \mathrm{H}$ with FS against basal heave from

field observations (Das, 1999 redrawn after Mana and Clough, 1981) ............... 18

2.8 Variation of ground settlement with distance from wall (Peck, 1969) ................ 18

2.9 Determination of strut loads; (a) section and plan of a cut; (b) method for determining strut loads (after Das, 1999) ................................................. 19

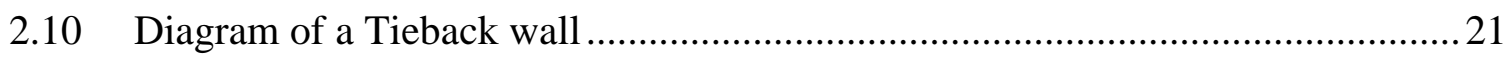

2.11 Overall Stability on a retaining device with tiebacks (after Weatherby

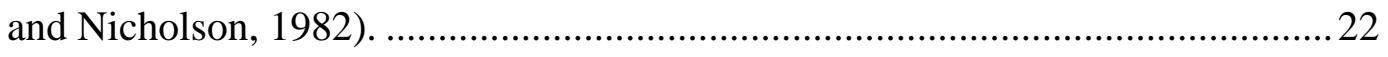

2.12 Coulomb Earth Pressure Diagram.................................................................. 24

2.13 Diagram of a Masonry/Concrete Wall ........................................................ 27

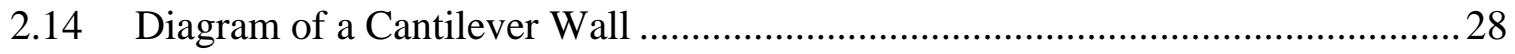


$\begin{array}{lll}\text { Figure } & \text { Page }\end{array}$

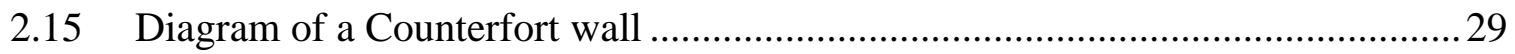

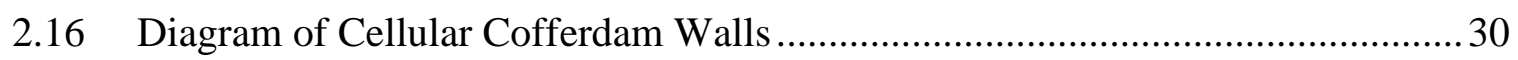

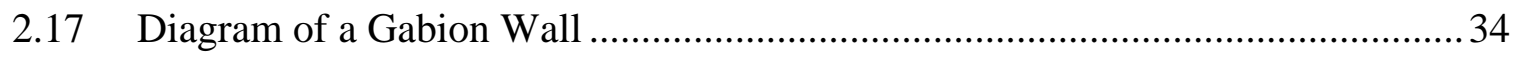

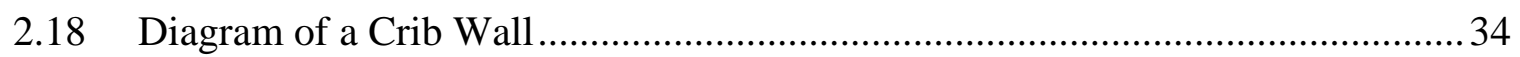

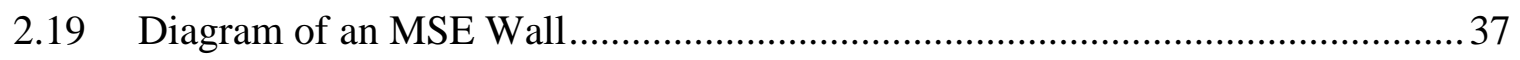

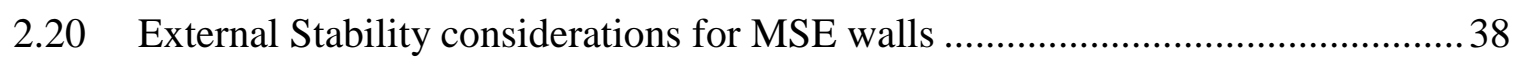

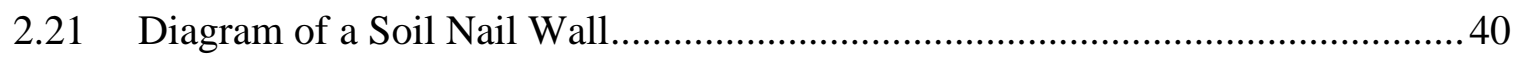

2.22 Diagram of Reticulated micro-piles (after FHWA, 1998) ................................ 41

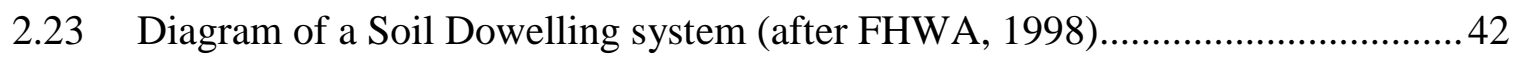

2.24 Diagram of a Tailed Masonry Wall.......................................................... 45

2.25 Adopted Retaining Devices Classification.................................................. 46

2.26 Proposed procedure for retaining device design (after Oliphant, 1997) ..............47

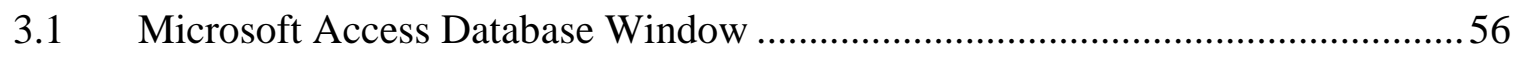

3.2 Microsoft Access Table Datasheet View .........................................................57

3.3 Microsoft Access Query Datasheet View .....................................................58

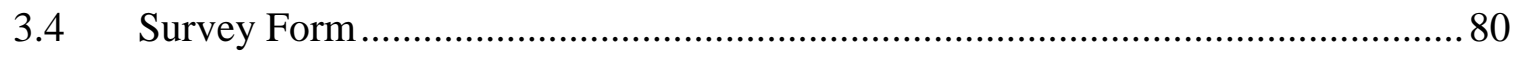

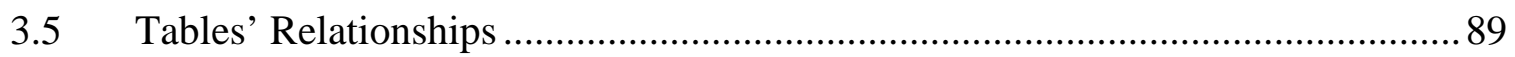

3.6 Form Case History Review: Literature .................................................. 90

3.7 Form Case History Review: Indiana ..................................................... 91

3.8 Select Query Example, :CHR Literature :Count Type Research ........................92

3.9 Select Query Example, :CHR Indiana :Count Type Research...........................93

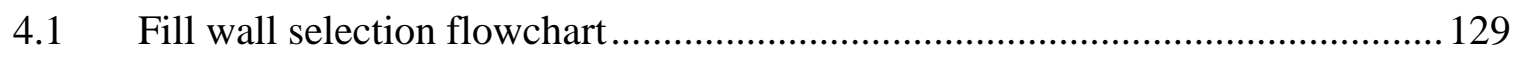

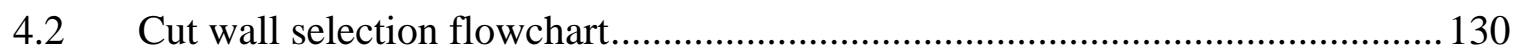




\section{IMPLEMENTATION REPORT}

A large number of types of retaining devices are currently available but their limitations, recommendations and guidelines are scattered in the technical literature. A synthesis study has been made in which different technologies are investigated to develop guidelines for the use of the different types of retaining devices. For this purpose, an extensive literature review has been performed and a new classification has been proposed; see the Retaining Devices Classification Chart. Retaining devices are divided into fill and cut walls. Fill walls support a backfill while cut walls support the natural ground. Fill walls are subdivided in: (1) Rigid and Cantilever Gravity Walls (RCGW); (2) Flexible Gravity Walls (FGW); and (3) Mechanically Stabilized Earth (MSE) Walls. Cut Walls are subdivided in: (1) Driven walls (DW); (2) Cast in-place Walls (CIPW); and (3) Soil Nailed Walls (SNW).

Databases can be used as decision-making tools since the information stored can be utilized for: (1) development of correlations and trends among the cases in the database; (2) comparison of a new wall design with the case histories in the database to determine similarities and differences between the projects. An electronic database with 207 selected cases from the technical literature and INDOT archives has been created.

The database stores the following information: (1) Type of Retaining Device, location; (2) Geometry: Dimensions (height, length, etc.); (3) Soil conditions: Foundation, backfill; 
(4) Experience and Performance (Service: Deformations during and after construction);

(5) Construction: Material used, construction process, problems; (6) Durability:

Maintenance records, type and cost; (7) Economy: Construction and maintenance costs;

(8) Other issues: special considerations, noise levels, etc.

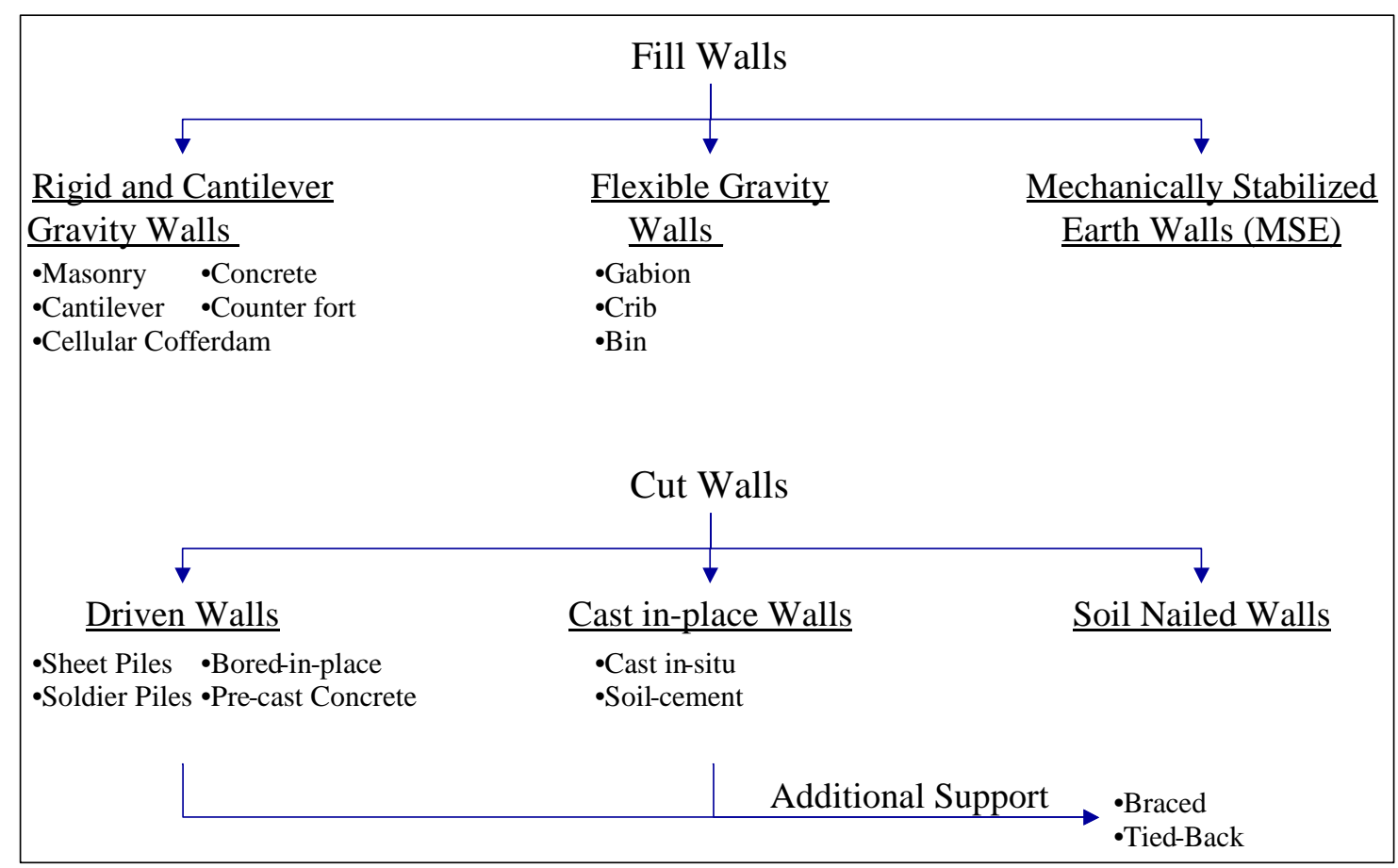

Retaining Devices Classification.

The information stored has been analyzed through a number of correlations. The following conclusions have been obtained:

(1) The most cost-effective type of wall for a given project depends on the height of the wall and on the soil conditions.

(2) For fill walls:

(a) Mechanically Stabilized Earth (MSE) Walls can tolerate large differential settlements; Flexible Gravity Walls (FGW) can tolerate differential settlements up 
to 1/50; and. Rigid and Cantilever Gravity Walls (RCGW) can only tolerate differential settlements up to $1 / 500$.

(b) The use of a fine-grained backfill without pore pressure considerations typically leads to failure of the wall. Freezing and thawing also leads to long-term progressive failure in a cohesive backfill.

(c) Corrosion of galvanized metallic elements is usually not significant.

(d) Compaction of the backfill around the connection of the reinforcement of MSE walls is usually reported as a problem.

(e) Large differential settlements in MSE walls can cause damage to the facing elements.

(f) MSE walls are the most economic fill retaining devices. If MSE walls cannot be used, Concrete and Masonry walls are the most cost effective devices for heights smaller than three meters. For larger heights, FGW are typically used.

(g) A flowchart for the selection of Fill Walls has been developed to identify the most cost-effective solution based on the height of the wall, cost, and soil conditions. 


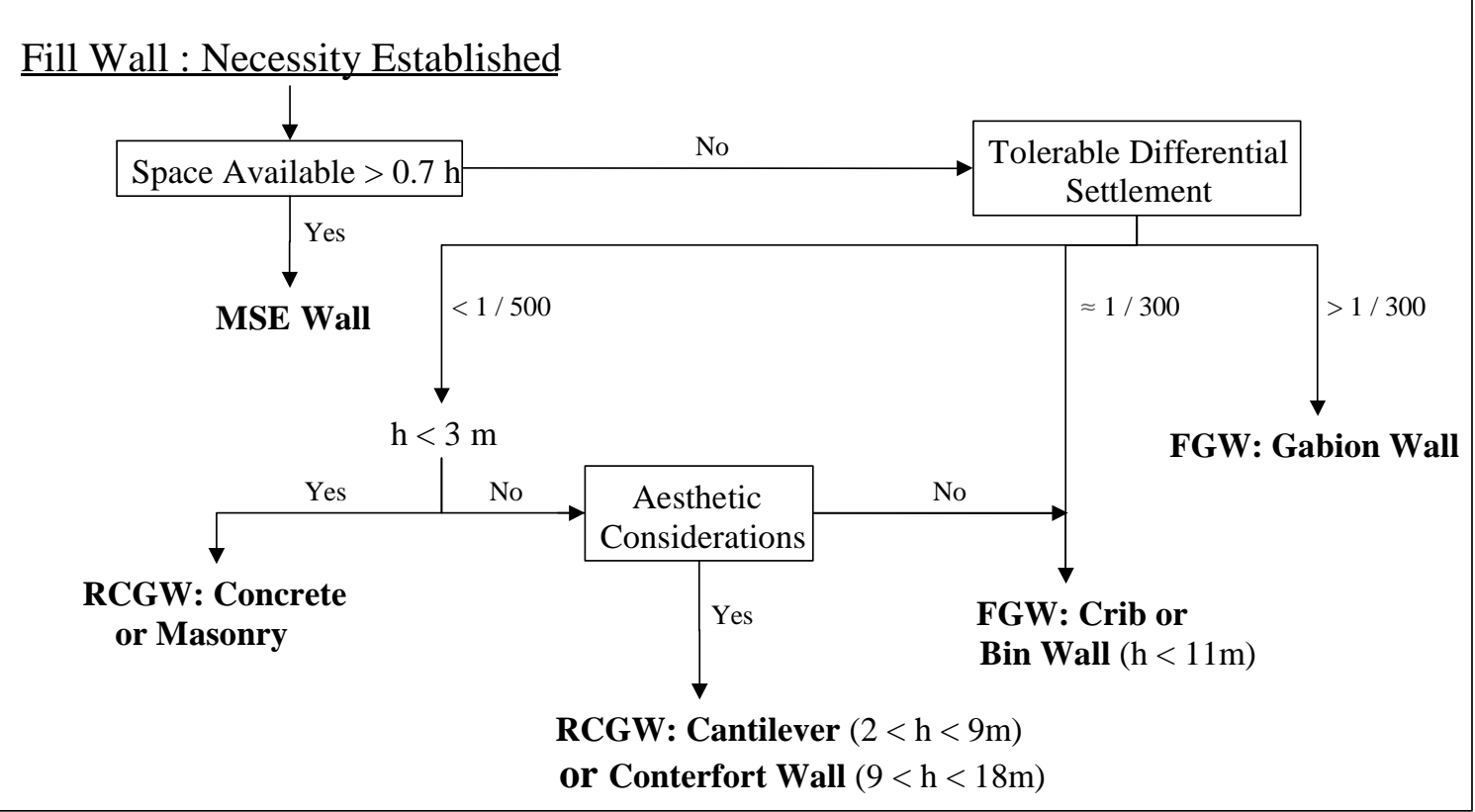

Fill Wall Selection Flowchart

(3) For cut walls:

(a) Driven Walls (DW) and Cast in-place walls (CIPW) above five meters require additional support systems.

(b) Additional settlement can occur in DW during construction if the time between excavation and placement of the lagging is too large.

(c) CIPW limit the ground settlements behind the wall.

(d) Soil nails have had a limited use because of lack of experience with their design and construction. They are not used in soils without sufficient frictional resistance, which is necessary to provide stability to the un-reinforced section of the wall immediately after excavation.

(e) DW are the cheapest cut retaining devices. Additional support for DW and CIPW higher than five meters is expensive, which makes Soil Nail walls more cost effective. CIPW are generally the most expensive option. 
(f) A flowchart for the selection of Cut Walls has been developed to identify the most cost-effective solutions based on the height of the wall, cost, and soil conditions.

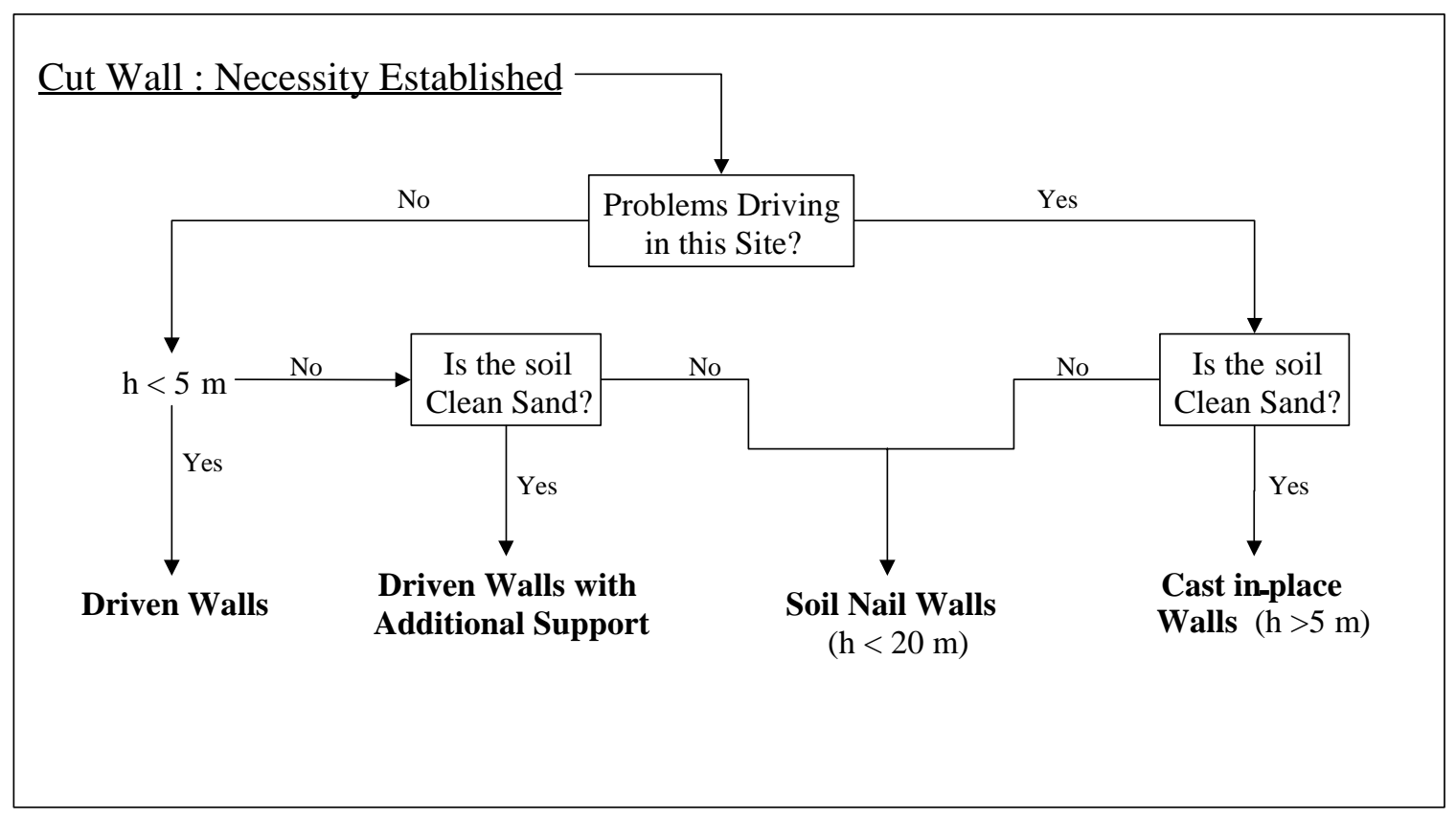

\section{Cut Wall Selection Flowchart}

(4) The problem most often reported in the database is the lack of a comprehensive geotechnical study.

(5) The conclusions obtained are in agreement with recommendations from the Federal Highway Administration (FHWA), and with specifications from the Indiana Department of Transportation.

The following recommendations are made:

(1) Use the flowcharts developed as a preliminary decision-making tool to decide the optimum type of wall for a given project.

(2) The flowcharts and additional notes provide general recommendations based on limited information. The flowcharts are not intended to cover all possible cases; they should be used for preliminary design and to facilitate engineering decision. 
Site-specific conditions or project constraints may require a different solution than that provided by the charts.

(3) The recommendations are based on up-to-date information. It is expected that with time design trends and wall typologies may become obsolete and new technologies may become available. It is recommended that the database and flowcharts be updated every five years.

The flowcharts presented have been developed for preliminary decision-making in the process of choosing the optimum retaining device for a given project. The flowcharts and the additional notes offer general recommendations and are not intended to cover all possible cases; site specific conditions or constrains may require a different solution. The conclusions of this study reflect the current design trends and wall typologies; the database and flowcharts should be updated every five years. 


\section{CHAPTER I. INTRODUCTION}

\subsection{Problem Statement}

Many devices and technologies are currently used for soil retention through the U.S. The State of Indiana is no exception. Designs with MSE Walls (Mechanically Stabilized Earth Walls), gravity walls (cast in place or prefabricated), soil nailing, soil stabilization, anchored walls, etc. can be found throughout Indiana. Each device or technology has limitations. There are recommendations and guidelines on how a particular retaining wall should be designed, when it can be used, or what maintenance requirements need to be observed. These guidelines are scattered through the technical literature, which makes it very difficult to decide the optimum solution for a particular site. Issues such as type of soil behind the wall, height, drainage, durability, safety, construction and maintenance costs, etc. need to be addressed.

The designer must have the freedom to choose the best design for a given project. However, the appropriate information must be readily available to make the best decision. A compilation and summary of guidelines and limitations for each type of technology will prove useful.

A synthesis study has been made in which the technologies most used in the U.S. and in Indiana are investigated as well as those emerging methodologies that show promise for 
future use in Indiana. This information is used to develop guidelines that are expected to provide better and cheaper designs of retaining devices in the State of Indiana.

\subsection{Scope of Study}

The requirements that a retaining device need to satisfy can be grouped into five categories: (a) Structural, (b) Service, (c) Durability, (d) Economy, (e) Social. The retaining device must have the capability of sustaining all possible loading actions that may occur during the life of the construction; that is, the stresses inside the structure must be within the material strength given the appropriate safety factors. In addition, it must provide the level of service and functionality for which it is designed. This requires that deformations be maintained within some specified tolerances. The design has to be durable and economical because the construction should require a minimum level of maintenance during its expected life. Finally, there may be non-technical (i.e. social) issues that have to be considered such as noise, aesthetic needs, etc.

There are many solutions that can be adopted for a particular problem. Each solution can be designed and tailored to fulfill requirements of structural integrity and serviceability; however, a particular solution may not be the optimum solution because of durability or socioeconomic issues. The best choice will depend on many factors, not all of which are technical. It is impossible to develop guidelines for the use of retaining devices that take into account all possible factors; instead this project investigates and classifies all solutions from a technical point of view. The classification is done according to the following factors: 
(1) Type of retaining device, location.

(2) Geometry: Dimensions (height, length, etc.)

(3) Soil conditions: Foundation, backfill.

(4) Service: Deformations during and after construction.

(5) Construction: Material used, construction process.

(6) Durability: Maintenance records, type and cost.

(7) Economy: Construction and maintenance cost.

(8) Other issues: special considerations, noise levels, etc.

These factors were collected from the technical literature, and from designs and data available at Indiana DOT.

\subsection{Anticipated Implementation and Benefits of the Study}

The goal of this research is to provide INDOT with quality information of existing technologies for retaining structures, and guidelines for optimum design. For the project an extensive literature search and a summary of the most relevant information were performed; this was done with close interaction with INDOT personnel. It is expected that this work will contribute to:

(1) Optimize the design of retaining devices.

(2) Decrease construction and maintenance costs.

(3) Provide a better understanding of the limitations and the proper usage of different retaining wall technologies. 


\subsection{Organization of the Report}

The report is organized as follows:

Chapter 2 Literature review on retaining technologies, classification and selection.

Chapter 3 Structure and layout of the database of the project

Chapter 4 Comprehensive analysis of the gathered data and guidelines for the selection of retaining devices

Chapter 5 Conclusions and Recommendations regarding implementation and future research. 


\section{CHAPTER II. RETAINING DEVICES}

A retaining device can be seen as a man-made construction arrangement that prevents earth from moving. However, a retaining device involves more than that. Retaining devices are needed in a large number of engineering projects and are very important in the development of land for construction. Sometimes they are the unseen and underrated heroes of a great human-feat, they help us give to the surface the shape that our designs require.

Retaining devices assist us in two basic scenarios: a fill or a cut. Different grades are often required for our engineering projects. Sometimes a fill has limited space, making long embankments an unfeasible option. Retaining devices reduce the slopes required for the difference in grade making the project possible. On the other hand, cuts require retaining devices to maintain stability or reduce settlements.

Before the 1970s, the predominant types of retaining devices for permanent structures were gravity and cantilever walls (Cheney, 1990). Gould (1990) describes the advances from the end of the Second World War until 1970. Most of the developments on retaining devices were made in excavation support. Slurry construction method and tieback anchoring were among the improvements. He also traces the beginning of soil nailing to France around 1972. The variety of choices for retaining devices was yet to be seen. 
Since then, a wide variety of new technologies have emerged. O' Rourke and Jones (1990) describe the changes and improvements of retaining devices for the next twenty years. Excavation support, in-situ wall construction, reinforced soils and soil nailing are the basic aspects they assessed. Attention is drawn to the rapid growth occurred on materials used in reinforced soils.

Today, a wide variety of retaining devices exist and are currently used for soil retention throughout the United States of America, including the State of Indiana. Gravity walls, Mechanically Stabilized Earth walls (MSE Walls), tieback walls and soil nailing, etc. are among the design options.

These devices have their limitations. Recommendations and guidelines are available on the design, when they can be used, or the maintenance requirements needed for a particular device. These recommendations are dispersed through the technical literature. This scatter makes it complex to opt for the optimum design on a project. Factors such as soil type, height, drainage, durability, safety, construction and maintenance costs, etc. need to be addressed.

The engineer should have the objective to select the best design for a given project. However, the appropriate information should be quickly and readily accessible to make the best decision. Therefore, a compendium and summary of guidelines and limitations for each type of retaining device is of practical interest.

This study investigates the technologies most used in the United State of America and the State of Indiana. The goal is to provide to the Indiana Department of Transportation with guidelines to decide what type of retaining device is more appropriate in a given project, from a geotechnical perspective. 
This chapter analyzes the different types of retaining devices. A literature review of the available retaining technologies and their classification is presented. It is not the intention to provide a step-by-step design code, but to show the basic design parameters and criteria for each retaining structure. Finally, the process of the retaining device selection is evaluated.

\subsection{Classification}

O' Rourke and Jones (1990) proposed a classification for retaining devices, which is presented in Figure 2.1. Their classification is the most referenced and adopted in the literature. Three main groups can be seen in this classification: Externally Stabilized Systems (ESS), Internally Stabilized Systems (ISS) and Hybrid Systems (HS). ESS are retaining devices that have an external structural wall on which the driving forces act. They achieve stability by using their own weight and/or wall stiffness as support. ISS are devices that have reinforcements installed within them and extending beyond the potential soil failure mass. The soil-reinforcement interaction provides the strength necessary for stability on these walls. HS combine elements from both systems. They use the external wall element of ESS and the soil-reinforcement interaction of ISS for support. O' Rourke and Jones' classification is slightly modified for our data collection and analysis purposes, and it is explained later in this chapter. The different types of retaining structures are explained through this chapter. 


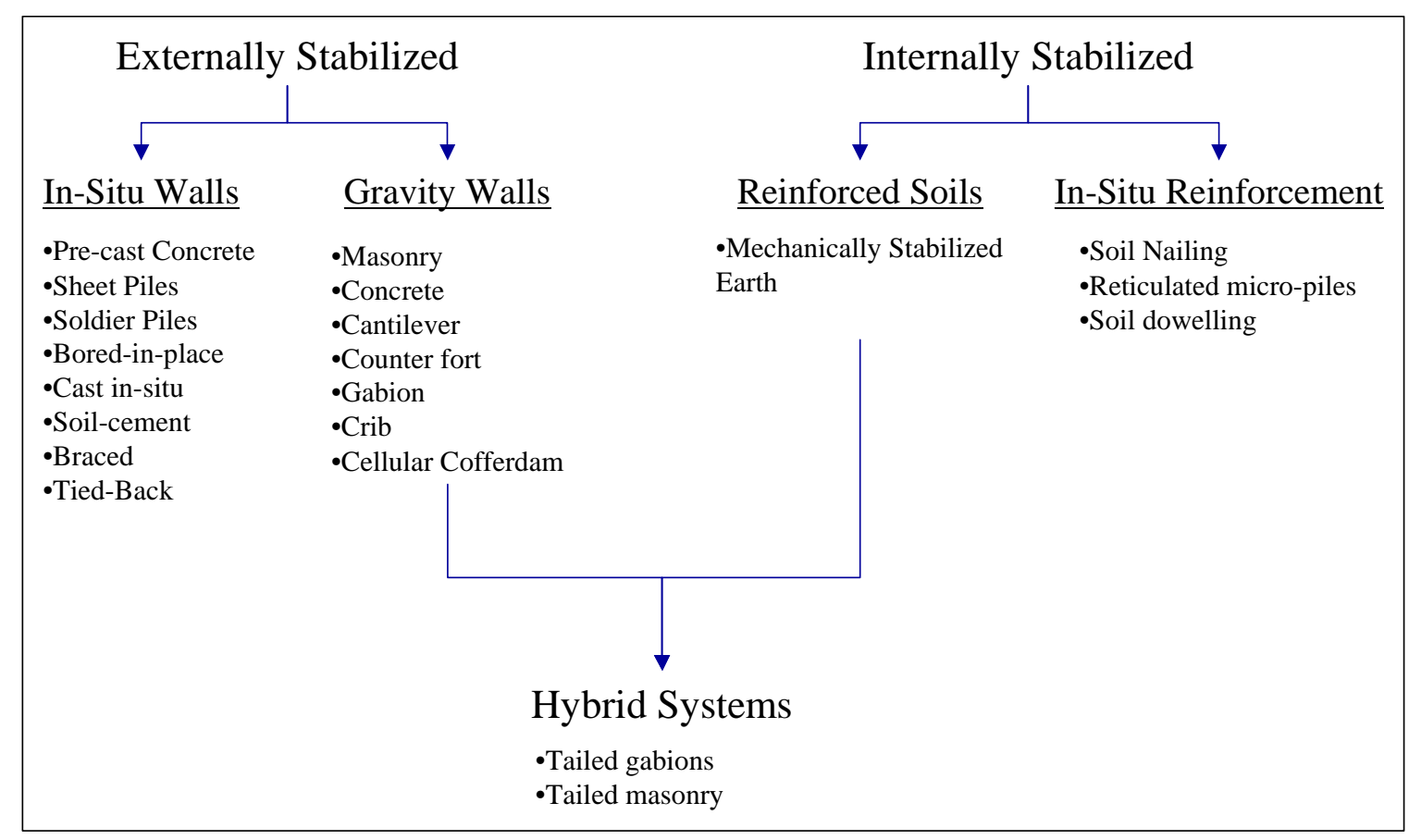

Figure 2.1 O’ Rourke and Jones (1990) Retaining Devices Classification

Each retaining device type within each classification, its issues and basic design are defined later in the chapter. The procedure to determine external forces and stability is included in the basic design. Only the most commonly used earth pressure for each type of retaining device is described. Overburden and design loads conditions vary greatly and are not discussed in detail because they fall outside the scope of our work. Nevertheless, the designer has to include these loads in the calculations.

Stability analysis of retaining devices comprises two aspects: external and internal stability. The external stability analyzes the behavior of the device and the surrounding soil. Internal stability studies the structural soundness of the retaining device. Both analyses usually require evaluating more than one condition, and vary with each device. 


\subsection{Externally Stabilized Systems}

Externally stabilized systems (ESS) are retaining devices with an external structural wall that supports the driving forces. These wall elements can use their own weight or stiffness to maintain equilibrium. Most of the traditional walls are ESS. They are divided in: In-situ walls and Gravity walls (Figure 2.1).

In-situ walls are retaining devices used in excavations, in which the main structural elements are constructed first and then "dug-up" to grade as the excavation advances. These retaining devices depend on the stiffness of a structural element to achieve stability. Typical examples of these walls are: Soldier piles walls and slurry walls.

Additional stability can be achieved for these walls with the addition of structural elements, either struts or anchors. Struts are horizontal steel beams placed between the opposing faces of a vertical excavation. Struts, or bracing systems, are used in excavations to provide lateral support against displacement. Anchors and tiebacks are steel rods or cables connected to and placed behind the structural wall element. The response between the soil and the anchor provides an additional lateral reaction for the structural wall.

Gravity walls are retaining devices for fill retention. These walls basically depend on the force of gravity to obtain stability. Examples of these walls are: Cantilever walls and gabion walls.

\subsubsection{In-Situ Walls}

In-situ walls are externally stabilized retaining devices for cuts. The stiffness of their structural elements gives the necessary conditions for stability. Figure 2.2 shows the basic 
diagram of an In-situ wall. The main structural elements are usually placed before the cut starts. Bracing and tiebacks can provide additional support for these types of walls.

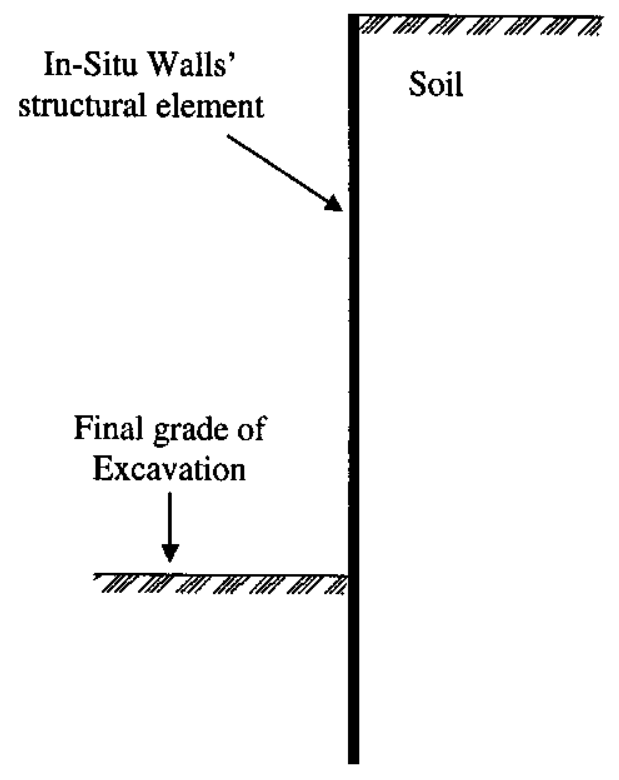

Figure 2.2 Diagram of In-situ walls

The external forces for these walls originate from the soil surrounding the wall, and are typically determined with Rankine's earth pressure theory. The lateral earth pressure against the wall is given by the effective vertical stress $\left(\sigma^{\prime}{ }_{v}\right)$ multiplied by a coefficient (k). Depending on the expected direction of movement of the wall the pressure will be active or passive. The lateral earth pressure will be active if the wall is expected to move away from the soil. If the expected movement is against the soil, the lateral earth pressure is passive. To obtain both the active and passive lateral earth pressures, coefficients for active $\left(\mathrm{k}_{\mathrm{a}}\right)$ and passive $\left(\mathrm{k}_{\mathrm{p}}\right)$ movement are needed. These coefficients are given by the following equations: 
Active Lateral Earth Pressure Coefficient $\quad k_{a}=\tan ^{2}(45-\phi / 2)$

Passive Lateral Earth Pressure Coefficient $\quad k_{p}=\tan ^{2}(45+\phi / 2)$

where: $\phi=$ the friction angle of the soil.

The following assumptions are made by Rankine's theory: there is no friction between the wall and the soil; the ground surface is horizontal and either the wall back is vertical or a full wedge can form in the backfill; the failure surfaces are planes; and the MohrCoulomb's Strength Theory is valid (Das, 1999). Further information on Rankine's earth pressure theory can be found in Das (1999), and Wang (2000).

The external stability of the walls is achieved when the following two conditions are met: $\Sigma$ horizontal forces per unit length of wall $=0$

$\Sigma$ moment of the forces per unit length of wall at a given point $=0$

The internal stability of the walls is ensured when each section of the wall can resist the maximum moment produced by the external forces (Das, 1999):

$$
\mathrm{S}=\mathrm{M}_{\max } / \sigma_{\mathrm{all}}
$$

where: $\mathrm{M}_{\max }=$ maximum moment that occurs at the point of zero shear; $\sigma_{\text {all }}=$ allowable flexural stress of the wall; and, $\mathrm{S}=$ section modulus of the wall per unit length.

For this report in-situ walls are further divided into two groups:

(a) Driven Walls; and,

(b) Cast in-place Walls.

The difference between these in-situ walls is that driven walls consist of pre-fabricated elements that are driven into the soil while cast in-place structural walls are fabricated during construction. 


\subsubsection{Driven Walls}

Driven walls (DW) are in-situ walls with a pre-fabricated structural element that is driven into the soil. The pre-fabricated elements are made of metal, wood or concrete. Each element can be driven completely into the ground or a portion might be left unburied to be used to elevate the existing grade. As the excavation advances down to the necessary grade, part of the pre-fabricated wall is dug-up. The buried part of the wall resists the soil movement, giving support to the unbalanced lateral earth pressures that result from the excavation. DW include the following types of walls: pre-cast concrete, sheet piles, soldier piles, and bored-in-place walls, which from a geotechnical point of view behave similarly. The basic difference between these retaining devices is their main structural element.

Pre-cast concrete walls are concrete piles driven into the soil. Sheet pile wall panels are made of wood, pre-cast concrete, steel or aluminum; the most common type is made of steel about $0.4 "-0.5$ " thick, with different sections and interlocking mechanisms available. Soldier pile walls are constructed with the soldier pile and lagging method, in which steel columns are driven into the soil; then after or during excavation lagging, e.g. wood planks, are placed between the soldier piles. The purpose of the lagging is to retain the soil while the arching effect allows the soldier piles to take the full earth pressure. Bored-in-place walls consist of concrete piles that are bored into the soil. Although this type of wall is not driven into the soil, its characteristics are similar to the walls of this group. This wall like the others in this group is made of prefabricated pieces that have to 
be delivered to the site with the required dimensions. Similar to soldier piles, they use the arching effect to support the soil. Lagging can also be used with this type of wall.

\subsubsection{Cast in-place Walls}

Cast in-place (CIPW) walls are in-situ walls with a structural wall element fabricated during construction. CIPW include the following types of walls: cast in-situ, and soilcement walls. From a geotechnical point of view these walls behave similarly.

Cast in-situ walls can be constructed with different cross sections, typically to satisfy the specific conditions of a site. The required section is excavated and then filled with a slurry, which is a mixture of water and clay, usually bentonite. This mixture prevents water from entering the excavation filling up the voids at the walls of the excavation; and also, prevents the collapse of the excavation. Once the excavation is completed, concrete is poured from bottom to top. The concrete displaces the slurry mixture since the specific gravity of the concrete is higher than the slurry. Once the concrete is poured a steel reinforcement, H-pile or bar cage, is placed to provide tensile strength. Depending on the cross-section, the walls may be described as tangent piles, secant piles, or slurry wall. Tangent and secant piles have a circular cross-section. The cross-sections of the piles of tangent walls, as the name indicates, are tangent to each other and the secant piles overlap each other. A slurry wall has a rectangular cross-section.

The Soil-cement method, developed in Japan, uses two or three-axis hollow stem augers to churn and mix the soil while water and cement are introduced from the auger's tip, therefore creating columns of soil-cement. H-piles are introduced into the soil-cement 
columns before hardening. A series of these columns are constructed to create a wall $\left(\mathrm{O}^{\prime}\right.$ Rourke and Jones, 1990). The soil-cement method can be used to give additional support to other walls, or as a treatment to harden the underlying soils. All the soil improvement walls are included in this group.

\subsubsection{Additional Support}

The stability of in-situ walls can be improved with various kinds of additional support. Bracing and tieback anchoring are able to give this additional support.

A bracing system is formed by struts and wales. Figure 2.3 shows a diagram of a braced excavation that shows an arrangement of struts and wales. Struts are horizontal steel beams placed between opposing vertical faces and wales are steel beams that distribute the load of the struts to the structural elements of the wall (Das, 1999). Struts work in compression and their load is dependent of the displacement of the wall. Bracing systems are used in excavations to provide lateral support, but they are often used as temporary systems required only during construction. Bracing usually decreases the soil deformation behind the wall, thus preventing settlements or bearing capacity failure of nearby foundations (Das, 1999). 


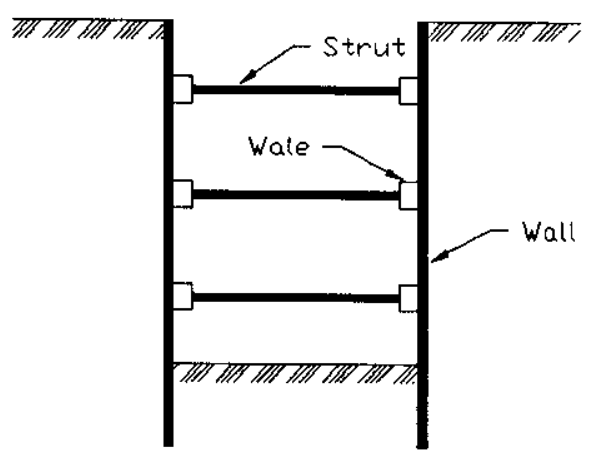

Figure 2.3 Diagram of a Braced excavation (after Das, 1990)

When this additional support is used the external forces are determined with Peck's Apparent Pressure Envelope. Figure 2.4 shows the pressure envelope for cuts in sand. The pressure $\mathrm{p}_{\mathrm{a}}$ is given by:

$$
p_{a}=0.65 \gamma H K_{a}
$$

where: $\gamma=$ the unit weight of the soil; $H=$ height of the cut; $K_{a}=$ Ranking earth pressure coefficient.

Figure 2.5 presents the pressure envelope for cuts in soft to medium clay, applicable when $\gamma \mathrm{H} / \mathrm{c}>4$, where: $\mathrm{c}=$ undrained shear strength of the soil. The pressure $\mathrm{p}_{\mathrm{a}}$ is given by the larger of the following:

$$
\begin{gathered}
p_{a}=\gamma H\left[1-\left(\frac{4 c}{\gamma H}\right)\right], \\
p_{a}=0.3 \gamma H
\end{gathered}
$$

Figure 2.6 shows the pressure envelop for cuts in stiff clay, applicable when $\gamma \mathrm{H} / \mathrm{c} \leq 4$. The pressure $p_{a}$ is given by:

$$
p_{a}=0.2 \gamma H \text { to } 0.4 \gamma H \text { (with an average of } 0.3 \gamma H \text { ) }
$$




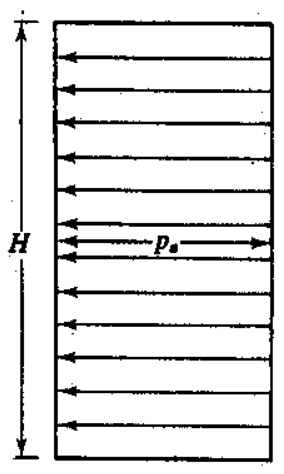

Figure 2.4 Peck's (1969) apparent pressure envelope for cuts in sand (after Das, 1999)

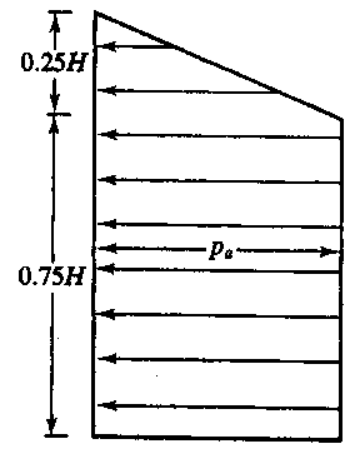

Figure 2.5 Peck's (1969) apparent pressure envelope for cuts in soft to medium clay (after Das, 1999)

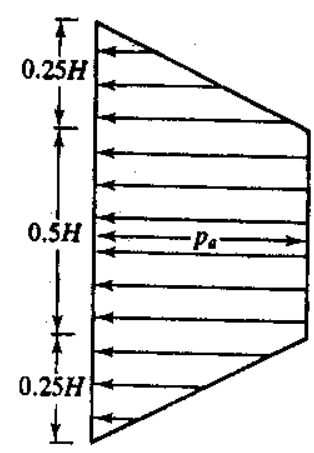

Figure 2.6 Peck's (1969) apparent pressure envelope for cuts in stiff clay (after Das, 1999) 
It is assumed that: the water table is below the bottom of the excavation; the sand is drained with zero pore water pressure; the clay is undrained and pore water pressure is not considered; the envelopes presented are apparent, the real pressure distribution is a function of the construction sequence and relative to the stiffness of the wall; and, the excavation depth is greater than six meters (Das, 1999).

External stability for bracing has to consider bottom heave, seepage forces, lateral yielding, and ground settlement.

Bottom heave may occur in clays. The Factor of safety against heave is given by:

$$
F S=\frac{0.7 N_{c}(c)(B)}{0.7(H)(B)-c(H)}
$$

where: $N_{c}=$ Terzaghi's bearing capacity factor; $c=$ undrained shear strength; $B=$ width of excavation; $\gamma=$ unit weight of the soil; $\mathrm{H}=$ excavation height. The factor against heave should be larger than 1.5. Piping may occur in sand excavations below the water table. The factor of safety against piping is given by:

$$
F S=\frac{i_{c r}}{i_{\max (e x i t)}}
$$

where: $i_{c r}=$ critical hydraulic gradient; $i_{\max (e x i t)}=$ the maximum exit gradient, which can be determined from flow nets.

$$
i_{c r}=\frac{G_{s}-1}{e+1}
$$

where: $G_{s}=$ specific gravity; $e=$ the void ratio. The factor against piping should be larger than 1.5. 


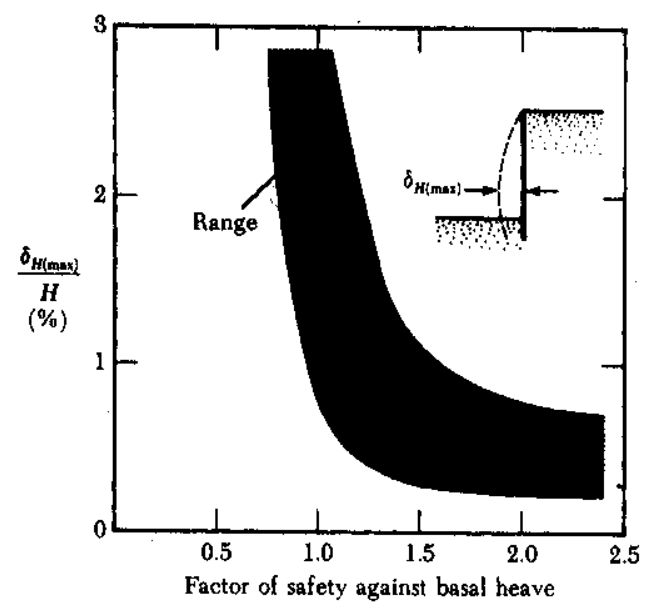

Figure 2.7 Range of variation of $\delta_{\mathrm{H}(\max )} / \mathrm{H}$ with FS against basal heave from field observations (Das, 1999 redrawn after Mana and Clough, 1981)

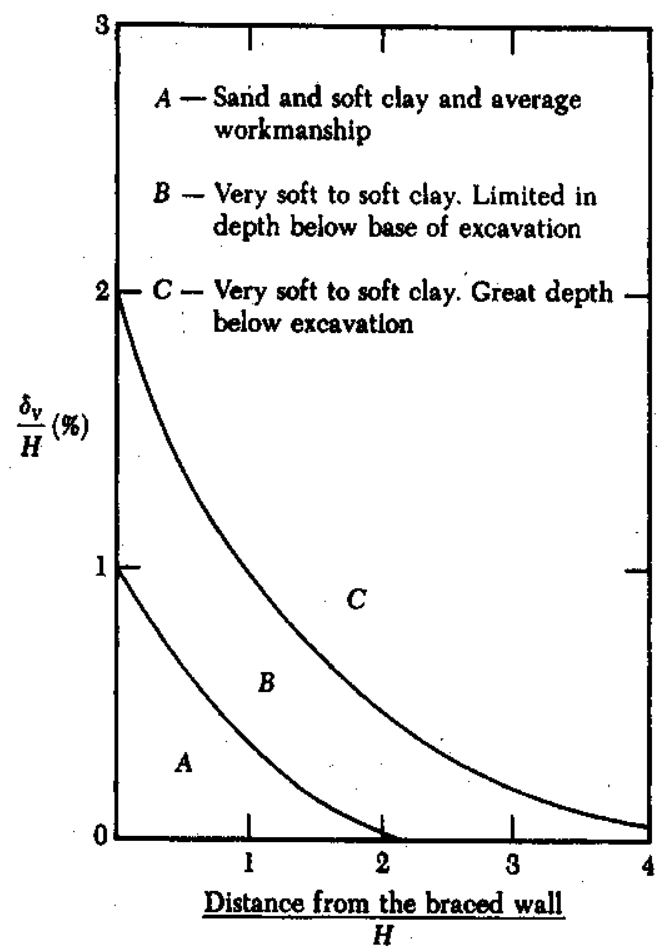

Figure 2.8 Variation of ground settlement with distance from wall (Peck, 1969) 
Lateral yield depends greatly on the time between excavation and bracing. A relationship between the lateral yield and basal heave is shown in Figure 2.7. The lateral yielding will induce ground settlement. Peck provides a graph to predict the ground settlement $\left(\delta_{v}\right)$ and is shown in Figure 2.8 (Das, 1999).
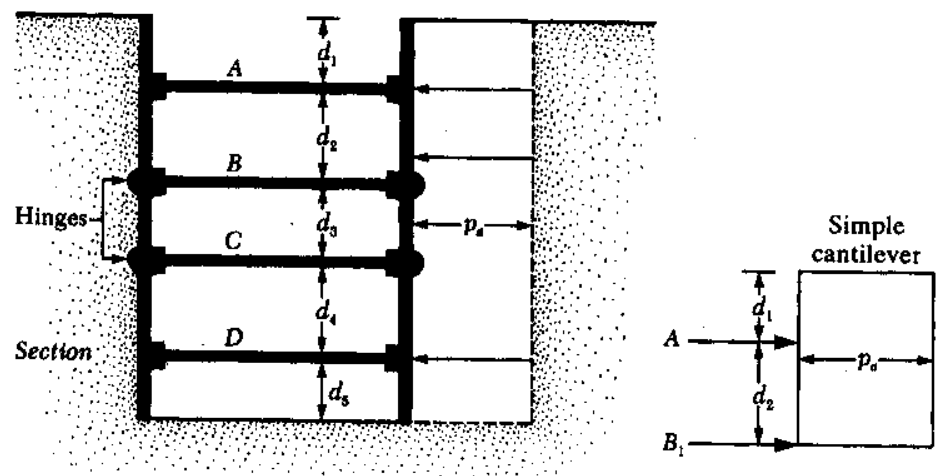

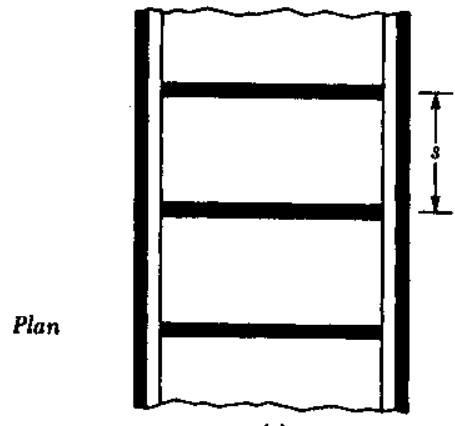

(a)

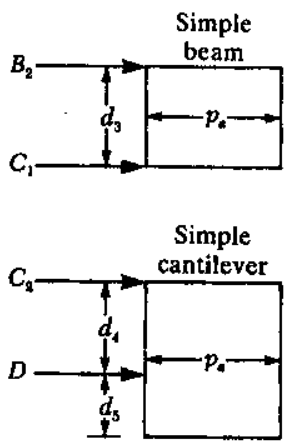

(b)

Figure 2.9 Determination of strut loads; (a) section and plan of a cut; (b) method for determining strut loads (after Das, 1999)

To evaluate internal stability, in addition to the wall internal stability checks previously mentioned in Section 2.2.1, the following has to be determined for the bracing support: the capacity and spacing of the struts, and the wales stiffness. The struts are designed as steel columns (refer to AISC, 1994). The loads on the struts are calculated assuming hinges at the ends of all the struts except for the top and bottom (shown in Figure 2.9). 
The result is two cantilever beams and simple beams between the struts. The load on each strut is then calculated adding the reactions and multiplying them by the spacing between struts. In construction struts have a minimum vertical spacing of about 2.75 meters. The first strut in clayey soils has to be below a depth $z_{c}$ that is given by:

$$
z_{c}=\frac{2 c}{\gamma \sqrt{K_{a}}}
$$

where: $c=$ undrained shear strength of the soil; $\gamma=$ the unit weight of the soil; $K_{a}=$ Ranking earth pressure coefficient.

Wales are considered pinned to the struts; therefore the maximum moments are given by:

$$
M_{\max }=\frac{P\left(s^{2}\right)}{8}
$$

where: $\mathrm{P}$ is the strut load at the wale level; $\mathrm{s}$ is the spacing between struts. The stability of the wales is ensured when its modulus section can resist the maximum moment (Das, 1999):

$$
\mathrm{S}=\mathrm{M}_{\max } / \sigma_{\mathrm{all}}
$$

where: $\sigma_{\text {all }}=$ allowable flexural stress of the wall; and, $S=$ section modulus of the wall per unit length of the structure.

A tieback is a structural element that uses a grouted anchor in the ground to secure a steel tendon, which applies a force to the structural wall (Weatherby and Nicholson, 1982). The interaction between the soil and the anchor provides additional lateral force to the retaining wall system. Figure 2.10 shows a diagram of an in-situ wall with tiebacks indicating the parts of the tieback. The anchor is the grout-bonded length, which mobilizes the shear resistance of the soil around its perimeter. The connection, or bearing 
plates, locks the load of the tendon against the wall. Tendons are made of steel wire generally used in structural post-tensioned applications.

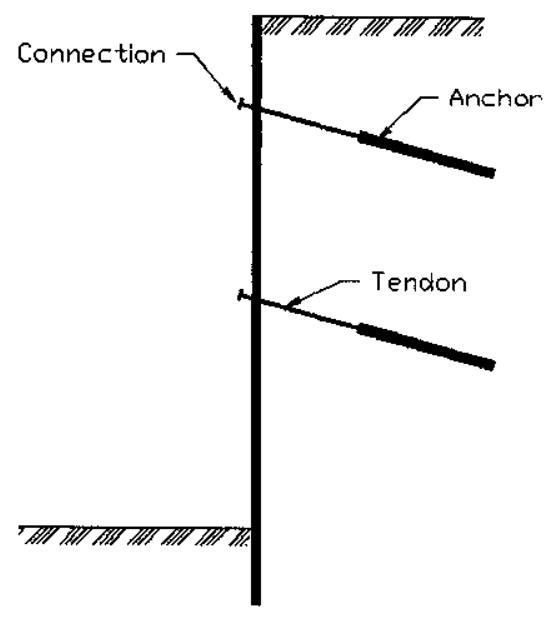

Figure 2.10 Diagram of a Tieback wall

Overall stability of the retaining system should be checked in addition to the external and internal stability checks described in Section 2.2.1. The retaining device can fail along a shear surface through the soil as shown on Figure 2.11. The surface can be a circle, plane, or log-spiral. The factor of safety is defined by:

$$
\mathrm{FS}=\Sigma \mathrm{M}_{\mathrm{r}} / \Sigma \mathrm{M}_{\mathrm{d}}
$$

where: $\Sigma \mathrm{M}_{\mathrm{r}}=$ sum of resisting moments against failure; $\Sigma \mathrm{M}_{\mathrm{d}}=$ sum of driving moments. The Modified Bishop Procedure or the Morgensten and Price methods can be used to calculate global stability (ASCE, 1997). Programs like STABL, which can evaluate correctly the behavior of a tieback, can also be used for the analysis. The anchored length of the tiebacks should be outside the critical failure surface as seen on Figure 2.11 (Weatherby and Nicholson, 1982). 


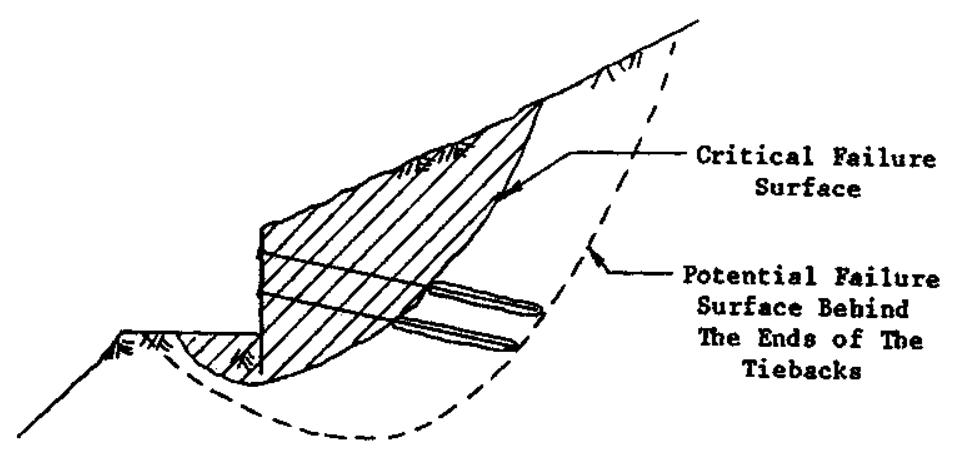

Figure 2.11 Overall Stability on a retaining device with tiebacks (after Weatherby and Nicholson, 1982).

In addition to the wall internal stability, as described in Section 2.2.1, the internal stability of the tiebacks has to be checked. This includes the anchor capacity (length and resistance of anchor and tendon) and the connection capacity. The tendon capacity is determined using an allowable stress approach, with the following equation:

$$
\mathrm{t}_{\mathrm{a}}=\mathrm{AR} \sigma_{\mathrm{u}}
$$

where: $t_{a}=$ tendon capacity; $A=$ the cross sectional area of the steel; $R=$ the percentage of allowable stress, normally computed at $60 \%$ of the guaranteed ultimate tensile strength for temporary work and $50 \%$ for permanent work; $\sigma_{u}=$ the guaranteed ultimate strength of the steel. The anchor capacity is usually determined from pullout tests performed on site. As a preliminary estimate, the ultimate anchor capacity can be calculated as:

$$
P_{u}=\pi d l f
$$

where: $d=$ nominal diameter of the grouted area; $1=$ length of the grouted area; $f=$ unit pullout resistance at the interface between the anchor and the soil or rock. The pullout resistance can be estimated with methods similar to those used to estimate skin friction on piles (ASCE, 1997). Corrosion protection is usually provided for the tiebacks. Weatherby 
and Nicholson (1982) report that there is no evidence of a corrosion failure on tiebacks that use cement grout for protection. However, they recommend that the tendon should be completely encapsulated in plastic if the surrounding soil has a $\mathrm{pH}$ less than 5.0 or a resistivity less than $2,000 \mathrm{ohm}-\mathrm{cm}$.

\subsubsection{Gravity Walls}

Gravity walls (GW) consist of structural wall elements that depend on their mass to obtain the necessary stability. They are generally used to support backfills. Examples of these walls are: Cantilever walls and gabion walls.

The external forces for these walls are generally determined with Rankine or Coulomb's earth pressure theories (Das, 1999). As described on Section 2.2.1, the lateral earth pressure can be active or passive. Rankine and Coulomb's theories use coefficients to obtain the lateral pressures. The following are the Rankine's lateral earth pressure coefficients:

Active Lateral Earth Pressure Coefficient $\quad k_{a}=\cos \alpha \frac{\cos \alpha-\sqrt{\cos ^{2} \alpha-\cos ^{2} \phi}}{\cos \alpha+\sqrt{\cos ^{2} \alpha-\cos ^{2} \phi}}$

Passive Lateral Earth Pressure Coefficient $k_{p}=\cos \alpha \frac{\cos \alpha+\sqrt{\cos ^{2} \alpha-\cos ^{2} \phi}}{\cos \alpha-\sqrt{\cos ^{2} \alpha-\cos ^{2} \phi}}$

where: $\alpha=$ the angle of the backfill surface with the horizontal; $\phi=$ the friction angle of the backfill. The same assumptions described in Section 2.2.1 apply to these equations. 


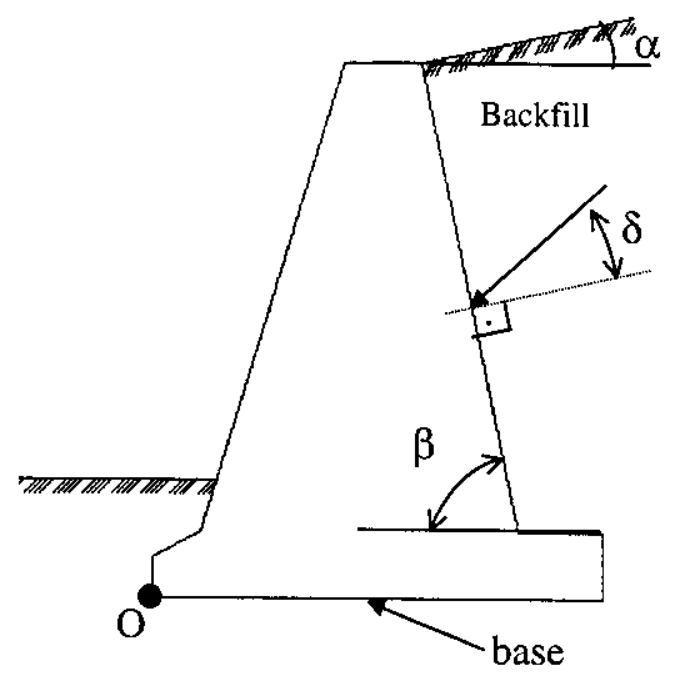

Figure 2.12 Coulomb Earth Pressure Diagram

The following are the Coulomb's lateral earth pressure coefficients:

Active Lateral Earth Pressure Coefficient

$$
k_{a}=\frac{\sin ^{2}(\beta+\phi)}{\sin ^{2} \beta \sin (\beta-\phi)\left[1+\sqrt{\frac{\sin (\phi+\delta) \sin (\phi-\alpha)}{\sin (\beta-\delta) \sin (\alpha+\beta)}}\right]^{2}}
$$

Passive Lateral Earth Pressure Coefficient

$$
k_{p}=\frac{\sin ^{2}(\beta-\phi)}{\sin ^{2} \beta \sin (\beta+\phi)\left[1-\sqrt{\frac{\sin (\phi+\delta) \sin (\phi+\alpha)}{\sin (\beta+\delta) \sin (\alpha+\beta)}}\right]^{2}}
$$

where: $\alpha=$ the angle of the backfill surface with the horizontal; $\beta=$ the angle of the wall facing the backfill with the horizontal; $\delta=$ the friction angle between the wall and the backfill (typically assumed between $1 / 2 \phi$ and $2 / 3 \phi$ for design); $\phi=$ the friction angle of the backfill. Angles $\alpha, \beta$ and $\delta$ are shown in Figure 2.12. 
The following assumptions are made with this theory: the failure surfaces are planar; and, the Mohr-Coulomb's Strength Theory is valid (Das, 1999). Further information on earth pressure theory can be found in Das (1999) and Wang (2000).

The external stability of these walls is determined with the following factors of safety: sliding failure, overturning, bearing capacity, settlement, overall stability, and other special factors (Das, 1999).

A sliding failure mechanism takes place when the earth pressure forces push the retaining device along its base (Figure 2.12). The factor of safety against sliding is given by:

$$
\mathrm{FS}=\Sigma \mathrm{F}_{\mathrm{r}} / \Sigma \mathrm{F}_{\mathrm{d}}
$$

where: $\Sigma F_{r}=$ sum of the horizontal resisting forces; $\Sigma F_{d}=$ sum of the horizontal driving forces.

Overturning is a failure mechanism in which the earth pressure forces produce a rotation along the toe of the retaining device, point "O" in Figure 2.12. The factor of safety against overturning is given by:

$$
\mathrm{FS}=\Sigma \mathrm{M}_{\mathrm{r}} / \Sigma \mathrm{M}_{\mathrm{o}}
$$

where: $\Sigma \mathrm{M}_{\mathrm{r}}=$ sum of resisting moments at the toe; $\Sigma \mathrm{M}_{\mathrm{o}}=$ sum of the overturning moments at the toe of the wall.

A bearing capacity failure occurs when the load imposed on the foundation is higher than the soil bearing capacity. The factor of safety against bearing capacity failure is given by:

$$
\mathrm{FS}=\mathrm{q}_{\mathrm{u}} / \mathrm{q}_{\max }
$$

where: $q_{u}=$ ultimate bearing capacity; $q_{\max }=$ maximum pressure produced by the wall.

Some GW are quite rigid, such as masonry and cantilever walls, and cannot withstand large settlements. Settlement calculations should be performed to determine the structural 
performance of the retaining device if large differential settlements are expected. Overall Stability is discussed in Section 2.2.1.3. Lastly, the earth lateral pressure is dependent on special factors such as: temperature, groundwater fluctuation, particle readjustment due to creep or rainfall, tidal changes, heavy wave action, traffic vibration, earthquakes. Their influence on the earth pressures and thus on stability should be taken into account. Factors of Safety should be in the following ranges:

Overturning

Sliding failure

Bearing Capacity
$\mathrm{FS} \geq(1.5-2.0)$

$\mathrm{FS} \geq 1.5$

FS $\geq 3.0$

For this report gravity walls are further divided into two groups:

(c) Rigid and Cantilever walls; and,

(d) Flexible gravity Walls.

Rigid and Cantilever walls, like their names imply, differentiate from flexible gravity walls because they cannot withstand differential settlements. Flexible gravity walls, because of their flexible characteristics, can tolerate larger differential settlements (FHWA, 1995).

\subsubsection{Rigid and Cantilever Gravity Walls}

Rigid and Cantilever Gravity Walls (RCGW) are massive and rigid retaining devices. These walls depend on their mass and gravity to provide resistance to the lateral earth pressures. They are made out of masonry, concrete, or reinforced concrete. Their elements are very rigid; therefore, with some differential settlement cracking may occur. RCGW include the following types of walls: masonry, concrete, cantilever, counterfort 
and cellular cofferdam walls. From a geotechnical point of view these walls behave similarly.

Masonry walls and Concrete Walls are generally massive, made of stone masonry and plain concrete, respectively. Figure 2.13 shows a diagram for these walls. The $\mathrm{W}$ on the figure represents the force of gravity working on this rather massive device, which is required to maintain stability. External forces and external stability procedures for these walls are discussed in Section 2.2.2. Internal stability is evaluated at any cross section of the wall stem. Because of the characteristics of these walls, no tension or a very small tension is allowed at any point in the cross section; this requires a rather large cross section.

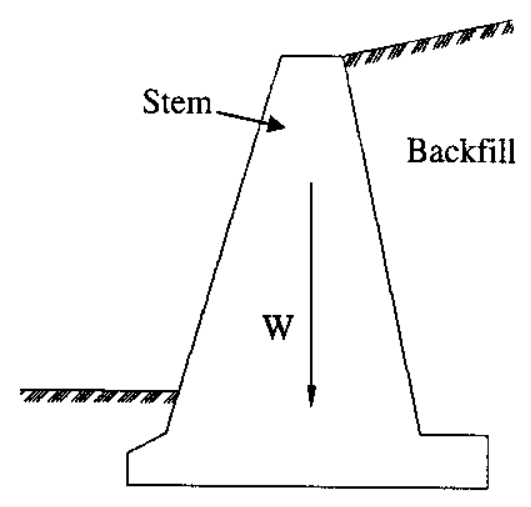

Figure 2.13 Diagram of a Masonry/Concrete Wall

Cantilever walls are made of reinforced concrete. They behave similarly to masonry and concrete walls but they have a thinner stem, as seen in Figure 2.14. The W on the figure represents the force of gravity working on this device, which is required to maintain stability. External forces and external stability procedures for these walls are discussed in 
Section 2.2.2. Internal stability is evaluated at any cross section of the wall stem. Although the stem is working in bending, as in masonry and concrete walls, the steel reinforcement allows thinner cross sections, because of its capacity of providing tensile strength. The design of the reinforced concrete structural elements (stem, heel and toe) must follow the American Concrete Institute Code (ACI, 1989). For the design of each element please refer to the most recent ACI Code.

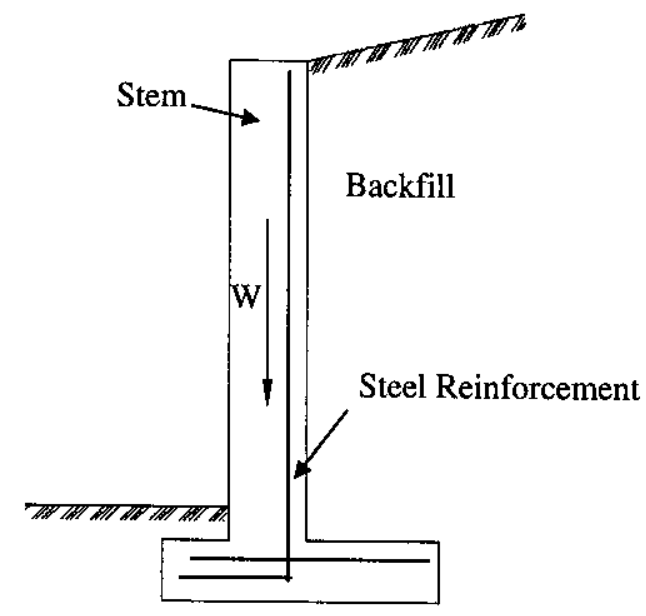

Figure 2.14 Diagram of a Cantilever Wall

Counterfort walls are cantilever walls with an additional structural element, called counterfort. Figure 2.15 shows a diagram of this wall, showing the counterfort element, which is a thin vertical slab. The counterfort can be either at the front or back (as shown in the figure) of the stem. In both positions the counterfort reduces the shear and bending moments on the stem. Counterforts are typically $0.30 \mathrm{~m}$ thick and spaced center-to-center at about a distance of $0.3 \mathrm{H}$ to $0.7 \mathrm{H}$, where $\mathrm{H}=$ height of the wall (Das, 1999). The same external forces, internal and external stability calculations as for cantilever walls have to 
be performed. Additionally the counterfourt slab also has to comply with the reinforced concrete criteria given by ACI (1989).

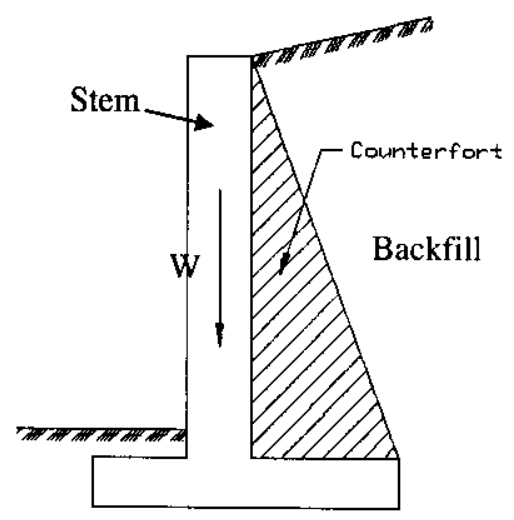

Figure 2.15 Diagram of a Counterfort wall

Cellular Counterfort walls are adjacent cells filled with soil or rock fragments. The cells are normally made by interlocking steel sheet piles. The cells of a cellular cofferdam can be arranged in straight lines or with uniform or variable curvatures. Figure 2.16 shows two cellular cofferdam arrangements. The first one shows circular cells arranged as an arch, the second one arranged as a full circle (Lacroix et al, 1970).

The external forces for cellular cofferdams are calculated with empirical correlations. Pressure coefficients, depending on loading conditions and location within the cell, are used to determine the lateral earth pressure (Lacroix et al, 1970):

During Initial Filling

$$
\mathrm{K}=0.4
$$

On unloaded side for prediction of maximum interlock stress

$$
\mathrm{K}=0.4
$$

On cell center plane for prediction of resistance to vertical shear

$\mathrm{K}=0.5$ to 0.6

On loaded side for prediction of sheet pile - cell interaction

$\mathrm{K}=0.7$ to 1.0 

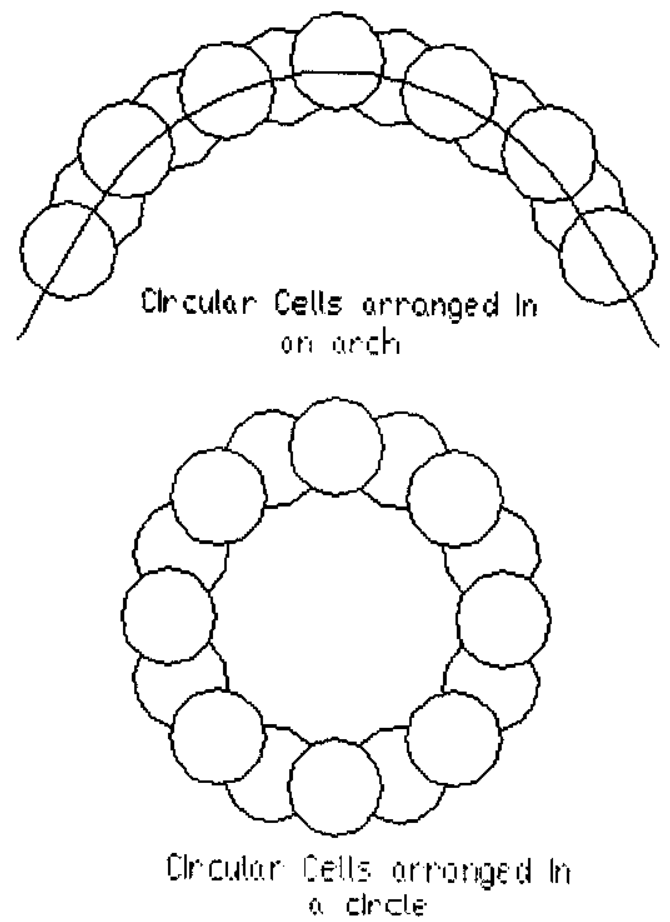

Figure 2.16 Diagram of Cellular Cofferdam Walls

The external force is then equal to $1 / 2 \gamma \mathrm{K} \mathrm{H}^{2}$, where $\gamma=$ unit weight of the soil; $H=$ the height of the cell; and, $\mathrm{K}$ the appropriate earth pressure coefficient.

The external stability for cellular cofferdams should comply with the following criteria: sliding along the base, overturning, excessive interlocking tension, bearing capacity (clays) and under seepage (sands).

Sliding along the base occurs when the unbalanced lateral forces push the cells along their base. The factor of safety against sliding is given by:

$$
F S=\frac{W^{\prime} \lambda}{P_{l}-P_{u}}
$$


where: $W^{\prime}=$ the effective weight of the cell fill; $\lambda=$ the coefficient of friction of the cell fill on the base; $P_{1}=$ horizontal total force on fill side; $P_{u}=$ horizontal total force on frontal side.

Overturning happens when the unbalanced lateral forces produce a rotation along the toe of the cell. The factor of safety against overturning is given by:

$$
F S=\frac{\Sigma M_{r}}{\Sigma M_{0}}
$$

where: $\Sigma \mathrm{M}_{\mathrm{r}}=$ sum of resisting moments at the toe, i.e. moment from $\mathrm{W}^{\prime} ; \Sigma \mathrm{M}_{\mathrm{o}}=$ sum of overturning moments at the toe, i.e. moment of unbalanced force.

Failure also occurs when the maximum interlocking tension surpasses the ultimate interlocking tension. Two conditions should be checked: (1) during initial filling of the cells; and (2) the most unfavorable combination of loads during regular conditions. The factor of safety against interlocking tension failure is given by:

$$
F S=\frac{t_{u}}{t}
$$

where: $t_{u}=$ ultimate interlock strength; $t=$ interlock tension $=p L ; p=$ horizontal total stress at a point on a vertical plane, $\mathrm{H} / 4$ above the base; $\mathrm{L}=$ average distance between cross-walls; $\mathrm{H}=$ height of cellular cofferdam.

Bearing capacity for cofferdams on clays should consider shear failure along the center plane of the cell. The factor of safety is given by:

$$
F S=\frac{P_{c}^{\prime}}{M_{o}} \frac{r f b}{L} \frac{L+0.25 b}{L+0.50 b}
$$


where: $\mathrm{P}_{\mathrm{c}}=$ horizontal effective force along the center vertical plane of the cell; $\mathrm{M}_{\mathrm{o}}=$ overturning moment; $r=$ radius of the circular cell; $f=$ coefficient of interlock friction; $b$ = equivalent width of cellular cofferdam, $0.8 \mathrm{~B}<\mathrm{b}<0.9 \mathrm{~B}$; L = average distance between cross-walls.

The factor of safety against piping is discussed in Section 2.2.1.3.

Factors of Safety should be in the following ranges (Lacroix et al, 1970):

Sliding along the base

Overturning

$(1.25<\mathrm{FS}<1.5)$

Excessive Interlocking Tension

Bearing Capacity [clays]

$(3.0<$ FS $<3.5)$

$(1.5<$ FS $<2.0)$

$(1.25<\mathrm{FS}<1.5)$

Finally for cofferdams, the internal stability analysis involves the evaluation of the shear on the center plane, tilting, and shear of the cell fill. Vertical shear failure on the center plane occurs when sliding along vertical planes take place. The factor of safety is given by:

$$
F S=2 b / 3 M_{o}\left[P^{\prime}{ }_{c} \tan \phi^{\prime}+\left(P_{d}-P_{u}\right) f\right]
$$

where: $b=$ equivalent width of cellular cofferdam, $0.8 \mathrm{~B}<\mathrm{b}<0.9 \mathrm{~B}$; $\mathrm{B}=$ total width of cellular cofferdam; $\mathrm{M}_{\mathrm{o}}=$ overturning moment about the toe; $\mathrm{P}^{\prime}{ }_{c} \tan \phi^{\prime}=$ shearing resistance of the soil along the center plane; $(\mathrm{Pd}-\mathrm{Pu}) \mathrm{f}=$ shearing resistance of the sheet pile interlocks; $f=$ coefficient of interlock friction.

Tilting of a cell depends on the horizontal shear strength of the cell fill and the interlock friction of the sheet piles. The factor of safety against tilting can be found with:

$$
\mathrm{FS}=\Sigma \mathrm{M}_{\mathrm{t}} / \Sigma \mathrm{M}_{0}
$$

where: $\Sigma \mathrm{M}_{\mathrm{t}}=$ sum of resisting moments about the toe of the cell; $\Sigma \mathrm{M}_{\mathrm{o}}=$ sum of overturning moments about the toe. 
Failure of the cell fill requires a shear failure at the interface between the cell fill and the steel sheet-pile. The factor of safety is given by:

$$
\left.F S=b / M_{o}\left[P^{\prime}{ }_{e}+P^{\prime}{ }_{a}+P^{\prime} d L\right) \tan \delta+P^{\prime}{ }_{c} f b / L\right]
$$

where: $\mathrm{b}=$ equivalent width of cellular cofferdam, $0.8 \mathrm{~B}<\mathrm{b}<0.9 \mathrm{~B}$; $\mathrm{B}=$ total width of cellular cofferdam; $\mathrm{M}_{\mathrm{o}}=$ overturning moment about the toe; $\mathrm{P}_{\mathrm{e}}=$ internal effective horizontal force on the loaded side; $\mathrm{P}_{\mathrm{a}}{ }_{\mathrm{a}}=$ horizontal active force on the loaded side, using Rankine's active theory; $\mathrm{P}_{\mathrm{c}}=$ horizontal effective force at the center vertical plane of the cell; $\mathrm{L}=$ average distance between cross walls; $\delta=$ friction angle between the soil and the sheet pile; $\mathrm{f}=$ coefficient of interlock friction. Factors of Safety should be in the following ranges (Lacroix et al, 1970):

Vertical Shear on center plane Tilting

Shear at the cell fill

$(1.25<\mathrm{FS}<1.5)$

$(1.25<$ FS $<1.5)$

$(1.25<$ FS $<1.5)$

\subsubsection{Flexible Gravity Walls}

Flexible Gravity Walls (FGW) are massive but flexible retaining devices. They consist of a confining structure, typically made of wood, pre-cast concrete, wire or steel elements interconnected and filled with rock or soil. FGW depend on their mass and force of gravity to provide resistance to the lateral earth pressures. The connections of the confining structures are flexible, therefore allowing, to some extent, differential settlements. FGW include the following types of walls: gabion, crib and bin walls. From a geotechnical perspective these walls behave similarly. 
Gabion walls are constructed with wire baskets, that are about $50 \mathrm{~cm}$ on a side, filled with rocks (Hunt, 1986). Figure 2.17 shows a diagram of a gabion wall. The wall in the figure has five levels of wire baskets.

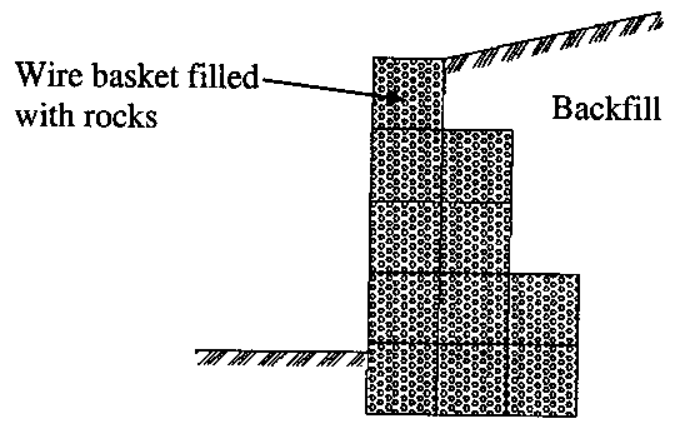

Figure 2.17 Diagram of a Gabion Wall

Crib walls are constructed with interconnecting boxes of timber, pre-cast concrete, or metal members, filled with crushed rocks. Figure 2.18 shows a diagram of a crib wall. Bin walls are made of interconnecting metal elements, filled with rocks or soil. Stability is obtained from the fill's unit weight, interlocking, and frictional strength.

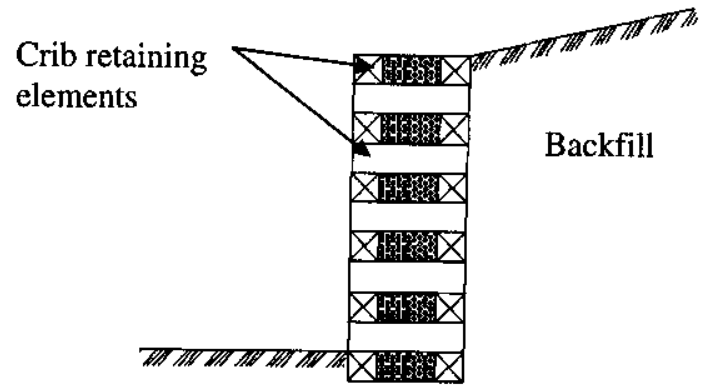

Figure 2.18 Diagram of a Crib Wall 
External forces and external stability procedures for these walls are discussed in Section 2.2.2. Internal stability calculations should check bin, crib or basket sliding and interlocking tension according to manufacturer's specifications. In addition to failing by sliding or overturning at the base toe, failure can also occur at the connections between elements. The connections between each raising element of the wall must be checked for sliding and overturning by taking into account the interlocking tension between the elements. Usually the manufacturer of these elements supplies the ultimate interlocking tension.

\subsection{Internally Stabilized Systems}

Internally Stabilized Systems (ISS) are retaining devices with reinforcements installed within the system. The reinforcement extends beyond the potential failure of the soil mass. ISS achieve stability thank to the strength provided by the soil-reinforcement interaction. The reinforcements are passive structural elements that take load as the ground deforms. ISS are divided in Reinforced Soil walls and In-situ Reinforcement walls (Figure 2.1).

Reinforced Soil walls are gravity fill structures built with soil, a tensile reinforcement, and a facing. Reinforced soils do not contain any rigid elements and can tolerate large settlements. A key aspect for the design is the accommodation of settlements without damage to the facing (O' Rourke and Jones, 1990).

In-situ Reinforcement walls are cut structures built incrementally from the top down, with a large quantity of closely spaced steel reinforcements driven into the soil, called 
soil nails. A soil nail is a structural element that takes load transferred from the ground, and is generally used in excavation reinforcement applications (FHWA, 1998).

\subsubsection{Reinforced Soils}

Reinforced Soil walls are fills constructed with intermediate layers of reinforcement. These walls use the mass and gravity force of the structure for stability. The construction is done incrementally with alternate layers of soil and reinforcement; because of this they can accommodate large settlements without compromising the structure's integrity. A facing for the retaining device is optional, and it depends on the type of system used to place the reinforcement. Special consideration should be taken to design the facing structure to accommodate settlements without damage (O' Rourke and Jones, 1990). Reinforced soils are also known as Mechanically Stabilized Earth.

\subsubsection{Mechanically Stabilized Earth}

Mechanically Stabilized Earth (MSE) consists of metallic, polymeric and/or organic reinforcing strips or grids that extend from the facing of the wall into the soil. The reinforcement serves the function of: (1) support of the backfill through frictional stresses between the strips and the soil; and (2) anchor any existing facing panels. The backfill on the one hand creates the lateral pressure that needs to be supported while on the other hand interacts with the strips to resist it (Koerner, 1998). Vidal (1979) explains that if the contact force between a grain of soil and the reinforcement makes an angle with the 
normal to the reinforcement smaller than the friction angle between them, the grain behaves as it were tied by the reinforcement. Therefore, it is considered that all the grains along a reinforcement are tied together. Figure 2.19 presents a diagram of a MSE wraparound geotextile reinforced wall, which shows the overlapping and embedment length. A geotextile is a polymeric reinforcement strip. Generally, MSE walls construction methods and elements are proprietary. Reinforced Earth, VLS, and Tensar are some of the systems available.
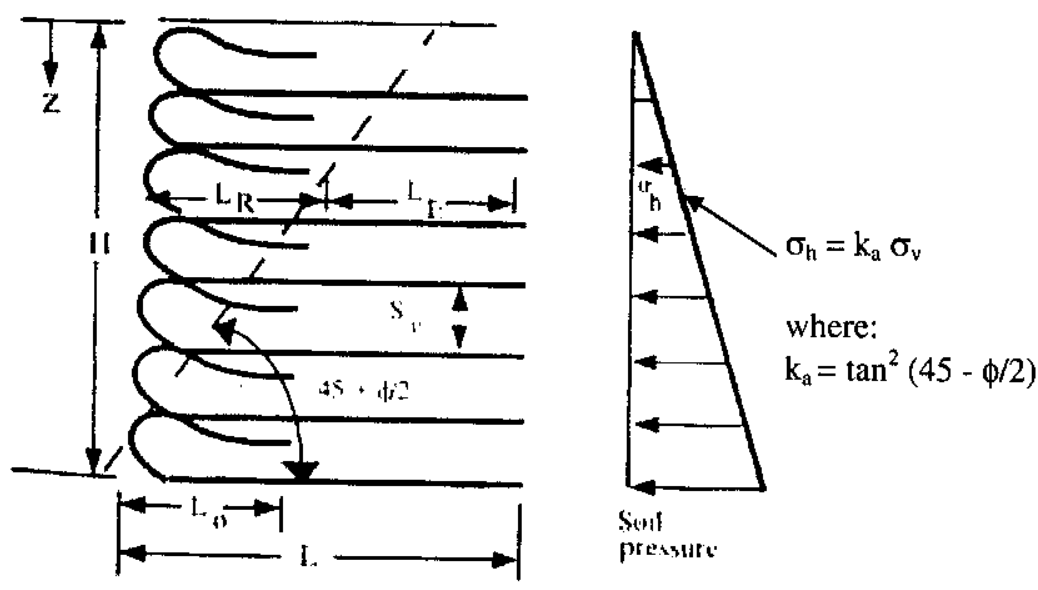

Figure 2.19 Diagram of an MSE Wall

External forces shown in Figure 2.19 are usually calculated by Rankine's earth pressure theory described in Section 2.2.1. External stability should comply with the following criteria: Sliding failure, overturning, bearing capacity and overall stability, as described in Sections 2.2.1.3 and 2.2.2. Figure 2.20 shows a graphical representation of three of these considerations: overturning, sliding and bearing capacity (foundation). The following ranges for factors of safety should be used (Koerner, 1998):

Overturning

Sliding failure

$(1.5<$ FS $<2.0)$

$(\mathrm{FS}=1.5)$ 


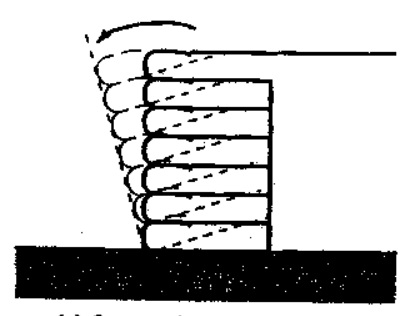

(a) Overturning considerations
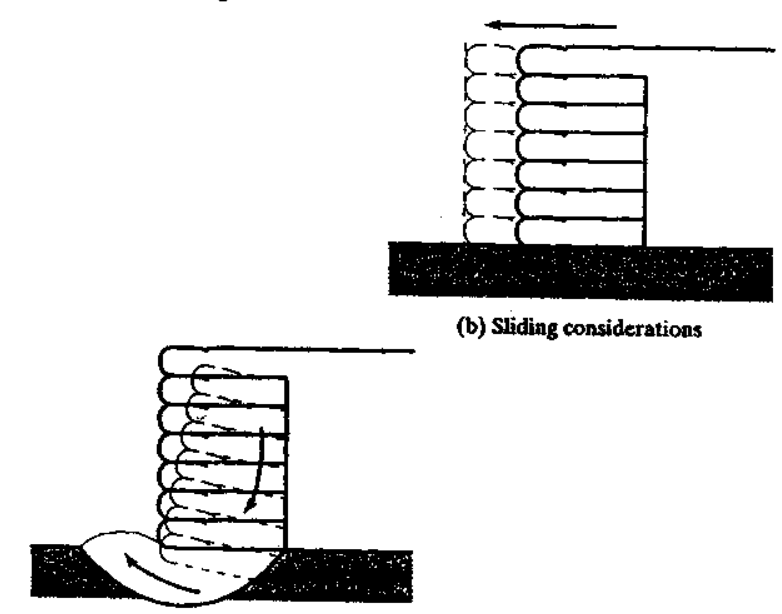

(b) Sliding considerations

(c) Foundation consideratrions

Figure 2.20 External Stability considerations for MSE walls

Internal stability depends on the type of reinforcement and facing. For the wall presented in Figure 2.19 the spacing, length and overlapping of the reinforcement have to be checked. The connection and facing system also have to be checked when present. (Koerner, 1998)

The vertical spacing $\left(S_{\mathrm{v}}\right)$ is given by the following equation:

$$
S_{v}=\frac{T_{\text {allow }}}{\sigma_{h} F S}
$$

where: $\mathrm{T}_{\text {allow }}=$ allowable stress in the geotextile; $\sigma_{\mathrm{h}}=$ total lateral earth pressure at the depth considered (from Rankine Theory); FS = factor of safety (between 1.3 to 1.5). 
The total length of reinforcement is given by: $L=L_{E}+L_{R}$, where $L_{R}=$ nonacting length of reinforcement and $\mathrm{L}_{\mathrm{E}}=$ the required embedment length. The nonacting length of reinforcement $\left(L_{R}\right)$ is given by:

$$
L_{R}=(H-z) \tan (45-\phi / 2)
$$

where: $\mathrm{H}=$ height of the wall; $\mathrm{z}=$ depth from ground surface; $\phi=$ shearing resistance angle of the soil. The required length of embedment $\left(L_{E}\right)$ is determined with the following equation (minimum $1 \mathrm{~m}$ ):

$$
L_{e}=\frac{S_{\nu} \sigma_{h} F S}{2\left(c_{a}+\gamma \tan \delta\right)}
$$

where: $S_{\mathrm{v}}=$ vertical spacing; $\sigma_{\mathrm{h}}=$ total lateral earth pressure at the depth considered (from Rankine Theory); FS = factor of safety; $c_{a}=$ soil adhesion between soil and geotextile (zero when granular soil is used); $\gamma=$ unit weight of soil; $z=$ depth from ground surface; $\delta=$ angle of friction between the soil and the geotextile.

The overlapping length $\left(\mathrm{L}_{0}\right)$ is determined with the following equation (minimum $1 \mathrm{~m}$ ):

$$
L_{o}=\frac{S_{\nu} \sigma_{h} F S}{4\left(c_{a}+\gamma z \tan \delta\right)}
$$

Internal stability for steel reinforcements is similarly done as with geotextile reinforcements. Chen (2000a and 2000b) studies the methodologies for the design of MSE walls with metal strips. Bourdeau et al (2001) analyze the construction and design of modular facing MSE walls and propose guidelines for the selection of MSE wall types. 


\subsubsection{In-situ Reinforcement}

In-situ reinforcement walls are retaining devices formed by a large quantity of closely spaced steel reinforcements driven into the soil, called soil nails. A soil nail is a structural element that provides load-transfer to the ground in excavation reinforcement applications to achieve stability. The nail consists of a steel element, which is commonly encapsulated in grout to provide corrosion protection and improve load transfer (FHWA, 1998). These retaining devices are employed in cut projects. They are built incrementally from top to bottom. This category includes the following types of walls: soil nailing, reticulated piles, and soil dowelling.

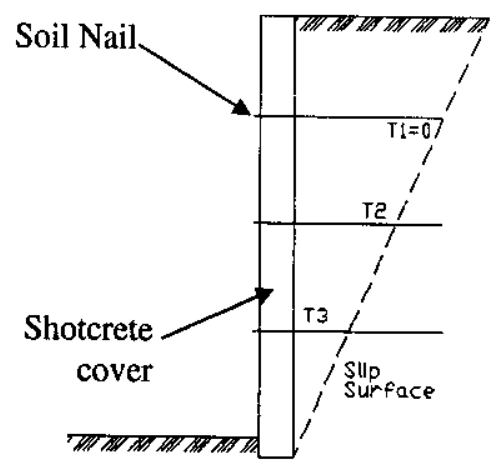

Figure 2.21 Diagram of a Soil Nail Wall

The soil nails are placed sub-horizontally and contribute to increase the stability of the retaining device by increasing the shear resistance along the potential plane of failure. Figure 2.21 shows a diagram of a soil nail wall. The process of soil nailing produces a reinforced ground area that is stable and able to retain the soil behind it. As the soil on top of the slip surface tries to move, it transfers loads to the nails, which in turn, due to their tensile strength, transfer the loads to the soil behind the slip failure where the nails 
are anchored. A facing of shotcrete is typically required and is often reinforced with a wire mesh (FHWA, 1998).

Reticulated piles consist of micro-piles steeply inclined into the soil at various angles both perpendicular and parallel to the face of the wall. The purpose of the piles, similar to soil nailing, is to provide a stable block of reinforced soil, which supports the soil behind by acting as a gravity retaining structure. Figure 2.22 shows a diagram of a reticulated micro-pile retaining structure on a slope of a road. The soil is held together by multiple reinforcement members acting to resist bending and shearing forces produced by the soil as it tries to slide (FHWA, 1998).

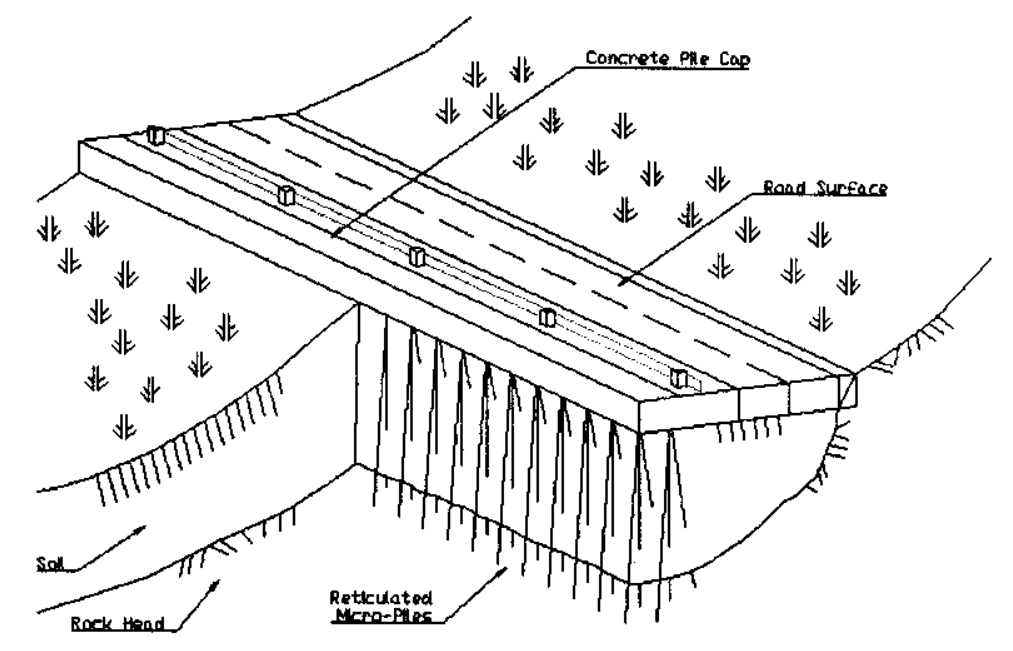

Figure 2.22 Diagram of Reticulated micro-piles (after FHWA, 1998)

Soil Dowelling uses relatively large diameter piles, which combine a large surface area with high bending stiffness to efficiently increase the shearing resistance. The slopes treated by soil dowelling are typically much flatter than those in soil nailing or reticulated micro-piles. This method is applied to reduce or stop down-slope movements on well- 
defined shear surfaces. Figure 2.23 shows a diagram of a soil doweling structure stabilizing a slope (FHWA, 1998).

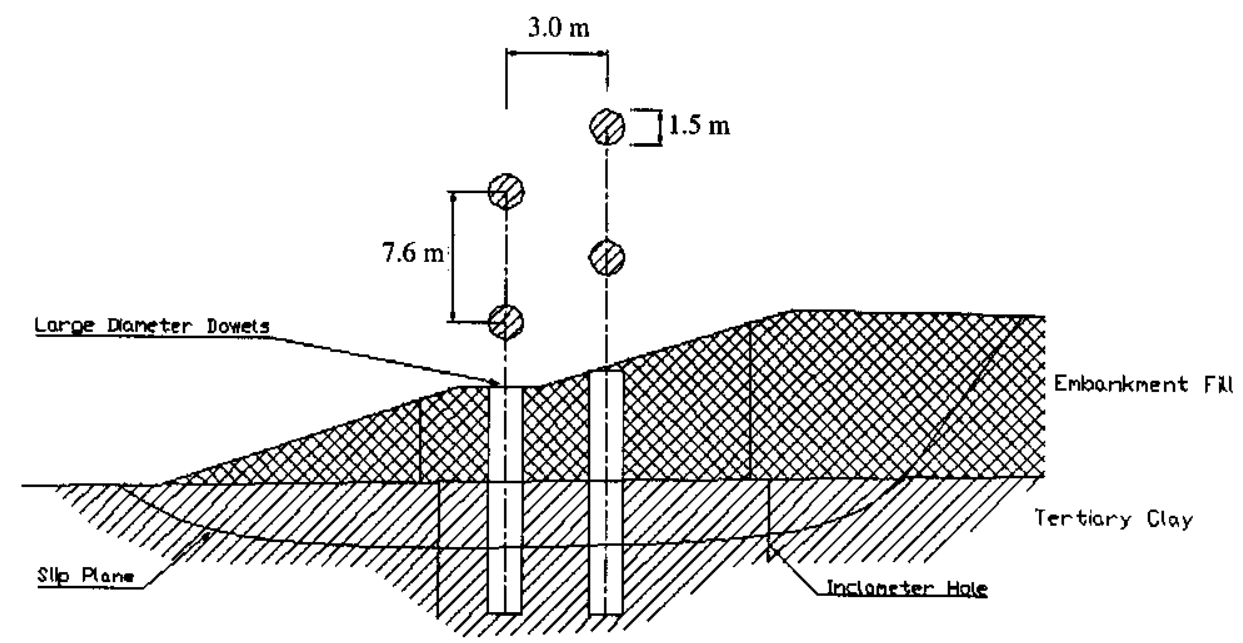

Figure 2.23 Diagram of a Soil Dowelling system (after FHWA, 1998)

\subsubsection{Soil Nailing}

Soil nail walls consist of a large amount of soil nails closely spaced and placed horizontally or sub-horizontally. A facing of shotcrete is typically required and is often reinforced with a wire mesh. A soil nail is a structural element composed of a steel tendon commonly bounded in grout to provide corrosion protection and improve load transfer. A soil nail differs from a tieback in that a tieback gives local support to an already exiting retaining device that supports the soil behind while a soil nail contributes to local stability by resisting the destabilizing forces and increasing the normal loads on the sliding surface. The process produces a reinforced soil volume that is stable and able to retain the soil behind it. The nails work mainly in tension but also work in bending and shear. However, often the contributions of bending and shear are not considered in 
design. The effect of the reinforcement in a soil nail wall is to improve stability by increasing the normal force and the soil shear resistance along the potential slip surface in frictional soils, and to reduce the driving force along potential slip surfaces in both frictional and cohesive soils. (FHWA, 1998)

External forces are determined with Rankine's earth pressure theory as described in Section 2.2.1. External stability should comply with the following criteria: Sliding failure, overturning, and overall stability. Sliding failure and overturning are described in Section 2.2.1.3. Overall stability is described in Section 2.2 .2 , however the contribution of the reinforcement should be taken into account. In Figure 2.21 there are three rows of soil nails and a slip surface. For the analysis it is assumed that only the part of the nails outside the failure surface contribute to global stability. The tension $(\mathrm{T})$ provided by the part of the tendons outside the failure surface is subtracted from the driving forces given in global stability equations.

Internal stability should consider in the design: block disintegration (tensile and shear strengths), the design scheme of nails (strength, length, bond capacity and horizontal and vertical spacing) and local stability of the facing. The maximum tensile strength of the nail $\left(\mathrm{T}_{\mathrm{NN}}\right)$ is given by:

$$
\mathrm{T}_{\mathrm{NN}}=\mathrm{A}_{\mathrm{b}} \mathrm{F}_{\mathrm{y}}
$$

where: $A_{b}=$ nominal area of the bar; $F_{y}=$ yield stress of the nail.

Ground-grout bond is dependent on the soil characteristics (plasticity, strength, grain size distribution), the drilling method and method of cuttings removal, and the grouting pressure, and usually requires a pullout test to determine the bond strength. Grout-tendon bond is typically higher than the ground-grout bond. The optimal distribution of soil nails 
is determined by trial an error. During design, the local stability of the facing is addressed with a field test cut where the face of the test cut should stand unsupported enough time to permit the installation of the nails and of the facing (FHWA, 1998).

The design of soil nail walls is presently based on limit equilibrium analysis. To evaluate the global stability of the soil nail mass and nearby ground, slope stability analysis have been developed that take into account the shearing, retention or pullout resistance of the nails outside the potential failure surfaces (Juran et al, 1990). The shape of the nail strength diagram and the sliding wedge shown in Figure 2.21 indicate that the contribution of the nail as reinforcement is a function of the location at which the slip surface intersects the nail. The contribution of any nail to the stability of a particular sliding block will be the least of: the tensile strength of the nail, the pullout resistance of the length of the nail beyond the slip surface, or the nail head strength plus the pullout resistance of the length of nail between the slip surface and the face of the wall. FHWA's Manual for design and construction monitoring of soil nail walls (1998) provide additional details and recommendations required for design.

\subsection{Hybrid Systems}

HS combine elements from ESS and ISS. They use the external wall element of ESS and the soil-reinforcement interaction of ISS for support. Examples of this systems are Tailed gabions and masonry. 


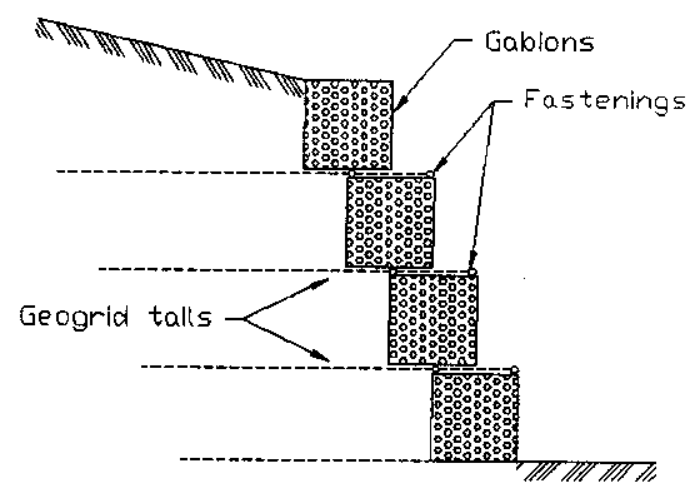

Figure 2.24 Diagram of a Tailed Masonry Wall

Tailed gabions and masonry combine a gabion or masonry structure, both previously mentioned, and geo-grid tails. Figure 2.24 shows a diagram of a tailed gabion, where the external wall provides a gravity retaining system and also a facing and connection of the tails. The tails are extended behind the gabion or masonry elements for additional tensile reinforcement of the soil. (O' Rourke and Jones, 1990) Requirements of both systems need to be complied as described in Sections 2.2.2.2 and 2.3.1.1.

Figure 2.1 presents the classification given by O' Rourke and Jones (1990) with the different systems categories and types of retaining devices. This classification has been slightly modified for this research. Figure 2.25 shows the new classification. The walls are grouped following the same concepts outlined in O'Rourke and Jones although the primary classification, fill or cut, is preferred since for most projects this is the first parameter described. The six categories shown in Figure 2.25 are used to group retaining devices with similar characteristics, and have been described in the previous sections. 


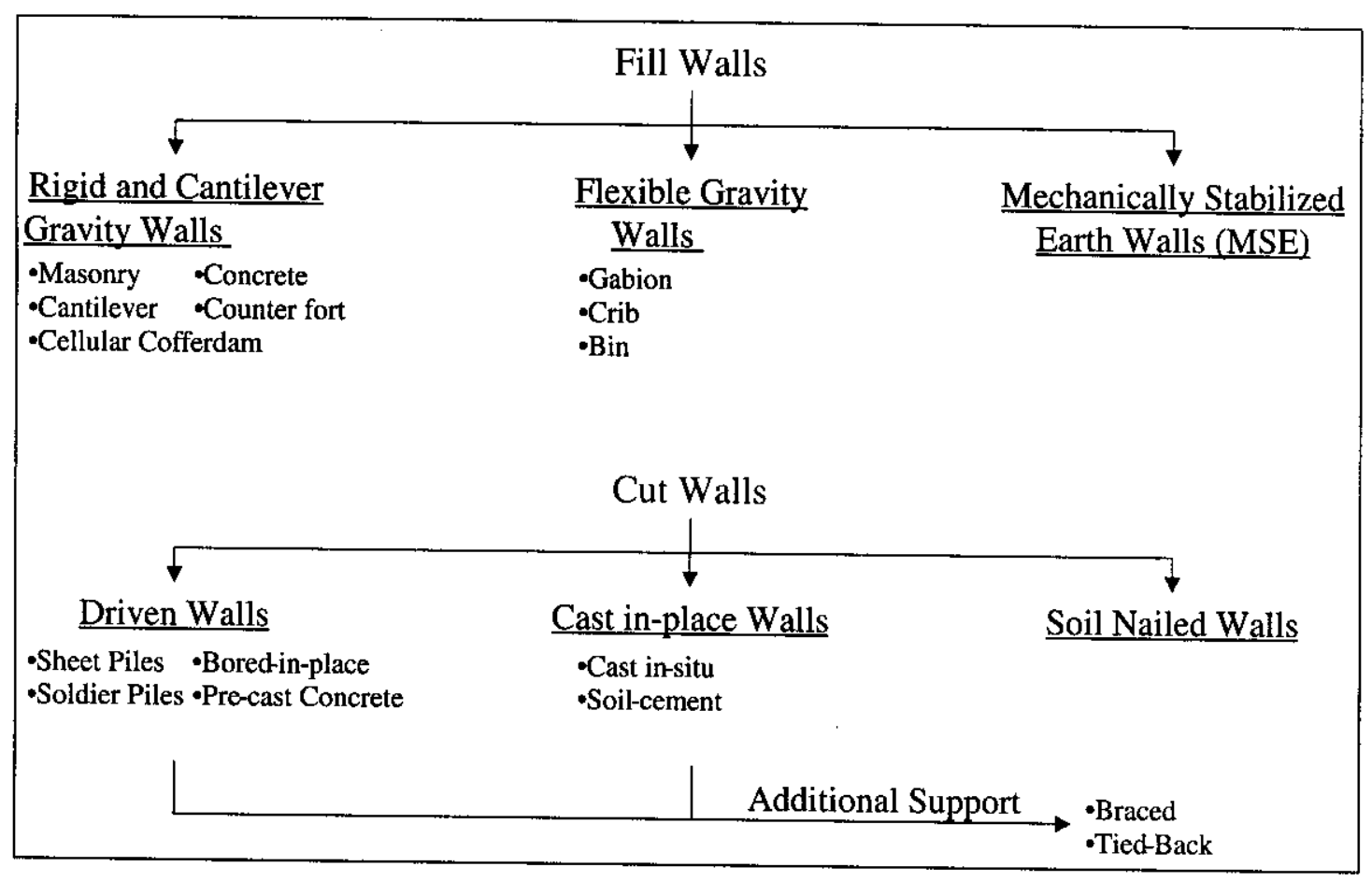

Figure 2.25 Adopted Retaining Devices Classification

\subsection{Wall Selection}

Once the need of a retaining device is established, a series of factors have to be considered to determine the optimum-retaining device for the specific needs of the project.

Munfakh (1990) proposes the use of the following factors to select retaining devices: ground, groundwater, construction considerations, right-of-way, aesthetics, durability and maintenance, environmental concerns, cost, politics and tradition. Ground factors include earth pressures, bearing capacity, settlement, and strain compatibility, to name a few. Groundwater is generally a factor that can be controlled with proper drainage. The purpose of controlling the groundwater is: to reduce the hydrostatic pressure; reduce the likelihood of corrosion of metal elements; and prevent displacements as a result of 
swelling. Construction schedule, availability of equipment and materials, site accessibility, and labor considerations are construction factors that should be considered. Right-of-way considerations relate to the space available for the construction of the retaining device. The look and aesthetics of the retaining device is a selection factor for permanent retaining structures where it is necessary to accomplish a good-looking or pleasing appearance for the project. Environmental issues like noise and vibration, as in any other project, also have to be taken into consideration.

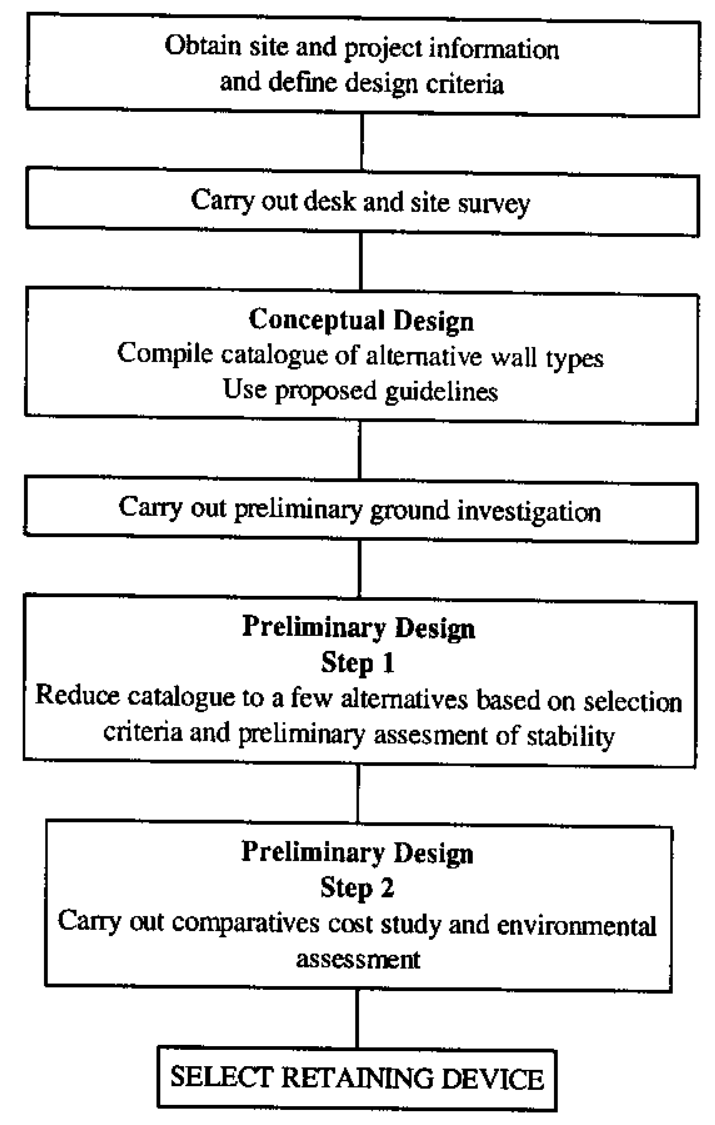

Figure 2.26 Proposed procedure for retaining device design (after Oliphant, 1997)

Oliphant (1997) proposes similar considerations with factors arranged in different categories. The study suggests a procedure for the selection and design of a retaining 
device and is shown in Figure 2.26. It proposes to perform desk and site surveys before any conceptual design is made. After this survey the choices of retaining devices are narrowed down and a preliminary soil investigation is performed. Preliminary design of the options can then be made. The continuity of site and soil investigations depends on the extent and size of the project.

The final choice is not necessarily straightforward. No factor may be more important than another, and combinations of all the requirements for the project need to be studied. Any good design procedure should consider the feasibility of a retaining device and then rate how the implementation of each option is affected by all the factors.

A database of retaining devices case histories, with analysis of the factors leading to their selection, can prove useful. Smith et al (1998b) continued Oliphant's previous work with the creation of a knowledge-based system to aid in the selection of retaining devices. The software is based on British Standards and a database of case histories. The system, called retwall, is run from a web page using HTML, JavaScript and java (Smith et al, 1998a). A java engine applet compares the factors and requirements of a project to the different types of retaining devices. It is available online for free at http://sbe.napier.ac.uk/projects/retwall/retwall.htm. This site should only be used as a quick reference.

Long (2001) also created a database of retaining devices for research purposes. The database was intended to analyze the ground and wall movements of in-situ walls, as described in Section 2.2.1. A large number of cases were included and the database proved useful for the analysis of several case histories. 


\subsection{Conclusions}

A large number of types of retaining devices are available. A comprehension classification of retaining walls is presented in this chapter. All retaining devices can be divided into two main groups: (1) Fill walls; and (2) Cut walls. Fill walls include all retaining devices that support a backfill, while cut walls include devices that support natural ground (i.e. support and excavation). Fill walls can be further classified as: Rigid and Cantilever gravity walls (RCGW); Flexible gravity walls (FGW); and Mechanically Stabilized Earth (MSE) walls. RCGW have been the basic choice for fill retaining devices for several years. Therefore, there is plenty of experience on the principles of design and construction of these devices making them very reliable. FGW share some of the principles of the RCGW, however their structural elements can withstand differential settlement. MSE walls is a relatively new technology, however numerous studies have been performed on its performance and reliability. MSE walls allow larger heights and differential settlements than RCGW and FGW.

Cut walls are further subdivided into: Driven walls (DW); Cast in-place walls (CIPW); and Soil nailed walls. DW and CIPW share common properties. However, DW are constructed with prefabricated members and CIPW members are constructed to satisfy the needs of an specific project. CIPW can be higher than DW since their cross-section can be modified and improved to satisfy that need. Soil Nail walls is another emerging retaining device with increasing interest and popularity. There has been relatively less use of these devices. Soil nail walls require less specialized equipment and high walls are constructed relatively faster than DW and CIPW. 
Selection of the most appropriate type of wall for a given project is a particularly complex task due to the large number of variables involved. Munfakh (1990) identifies the following factors: ground, groundwater, construction considerations, right-of-way, aesthetics, durability and maintenance, environmental concerns, cost, politics and tradition; and Oliphant (1997) proposes a rational procedure for the wall selection. However what has been shown useful for the design of walls is the development of databases with case histories where the problem at hand can be checked and correlated with well-documented case histories. 


\section{CHAPTER III. DATABASE OF RETAINING DEVICES}

A database is a set or collection of information regarding a particular topic or purpose. They can keep track of key data of engineering projects. An electronic database helps to organize information from different sources into one medium. Another of its capabilities is the capacity to add, delete or link information or categories. Once the information is gathered in an electronic database, analysis and cross-reference of key elements collected can be performed quickly.

A database of retaining devices case histories was compiled to assist in the development of guidelines for their use. The compilation includes a large number of factors from each case to help with the selection of the retaining device. The factors stored are:

(a) Type of Retaining Device, location;

(b) Geometry: Dimensions (height, length, etc.);

(c) Soil conditions: Foundation, backfill;

(d) Experience and Performance: Service, Construction, Durability, Economy, and Other special considerations.

Information in a database is stored in records and fields. A record contains all the information regarding a case history. A field is a specific data item stored for a case history. Therefore, every case history has its data stored in different fields within its own record. Every factor has its own field. The complete electronic database created is stored 
in a single file called SPR2466.mdb; the file is included in this report in the digital media attached. This chapter introduces the basic database terminology and explains the created database structure and layout. Also some examples are presented to describe the capabilities of the database.

\subsection{Scope}

Oliphant (1997) points out the following factors that should influence the design of any retaining device:

(a) Ground, and groundwater;

(b) Proposed height and ground topography;

(c) Availability of materials and specialist equipment;

(d) Construction space available;

(e) Ground movements and external loads;

(f) Design life and maintenance requirements;

(g) Underground obstructions;

(h) Appearance; and,

(i) Confidence in design and construction.

These factors can be grouped into five categories: (a) Structural; (b) Service; (c) Durability; (d) Economy; and, (e) Social. The retaining device must have the capacity of sustaining all possible loading conditions that may take place during the construction and the life of the structure; namely, the stresses inside the structure must be within the material strength at all times given the appropriate safety factors. The device should also supply the level of service and functionality for which it is designed. Therefore, the 
deformations need to be within some specified tolerances. The design has to be durable and economical because the construction should require a minimum level of maintenance during its expected life. Finally, there may be non-technical issues that have to be considered such as noise, aesthetic, environmental, etc.

There are many solutions or retaining devices that can be chosen to resolve a particular problem. Each solution can be designed and tailored to fulfill all structural and serviceability requirements. However, a particular solution is not necessarily the optimum solution, because of durability, social or economical issues. The best option depends on many factors, some technical, some social, etc. Although it is not feasible to develop guidelines for the use of retaining devices taking into account all possible factors, it is useful and practical to classify all solutions from a technical point of view. This is the purpose of this project.

A compilation of retaining devices case histories was performed to assist in the development of these guidelines. The compilation includes the factors leading to the retaining device selection for each case. The factors gathered are the following:

(a) Type of Retaining Device, location;

(b) Geometry: Dimensions (height, length, etc.);

(c) Soil conditions: Foundation, backfill;

(d) Experience and Performance:

- Service: Deformations during and after construction;

- Construction: Material used, construction process, problems;

- Durability: Maintenance records, type and cost;

- Economy: Construction and maintenance cost; 
- Other issues: special considerations, noise levels, etc.

This information has been collected from the technical literature, from designs and data available at Indiana DOT, and designs from contractors and designers in the State of Indiana. This is done to encompass all possible options and yet specifically incorporate the experience available in the State of Indiana. Furthermore it is the goal of this work to facilitate the access of all this information. For that purpose, all the information is stored in a dynamic, upgradeable, electronic database.

\subsection{Database Software: Microsoft Access}

The software selected to develop our database is Microsoft Access 2000 (MSA). Access is selected because of its popularity and versatility. As a part of the Microsoft family, Access is sometimes bundled with the Microsoft Office Package. This fact alone makes this program a common tool in most computers. Access has the capability to easily exchange its information with formats from other programs from Microsoft such as Microsoft Word and Microsoft Excel. Access allows accessibility of the data stored within it from most systems.

In this section some basic definitions and operations with MSA are presented. The goal is to introduce and explain a number of concepts that are necessary to understand how the program works, its possibilities and limitations. It is not intended to be a manual to operate the database. The interested reader is referred to the Microsoft Access User's Manual (Microsoft, 1999). 
MSA is capable of producing reports and charts of the data stored. Updates of the information stored are automatically reflected in previously produced reports and charts. This proves of great help in analyzing the data.

Access manages all the information in a single database file. Information can be saved within the database file into different storage compartments. These storage compartments are called tables.

A table is a collection of data about a specific topic, such as soil or retaining devices classification. Using a different table for each topic means that the data is stored only once, which makes the database more efficient, eliminates redundancy, and reduces dataentry inconsistencies. (Microsoft, 1999)

Objects from an access database file, such as tables, queries, forms, reports, etc. can be easily managed with the database window. Figure 3.1 shows the database window for a new file. On the left side of the window there is a list of database objects. Changing the selection from this list shows the existing objects on file. In the Figure "Tables" is selected; therefore, the window shows the existing table objects in the database. Tables as mentioned before store the data; and they can be used to add, view or edit data. Forms are used to add, view, or edit data stored in tables. Queries are used to find and retrieve data. Reports analyze and prepare data for printing. Once objects are created in a database, relationships defined between tables bring together information from different tables. For descriptions of other MSA objects refer to the Microsoft Access Help Manual (Microsoft, 1999). 


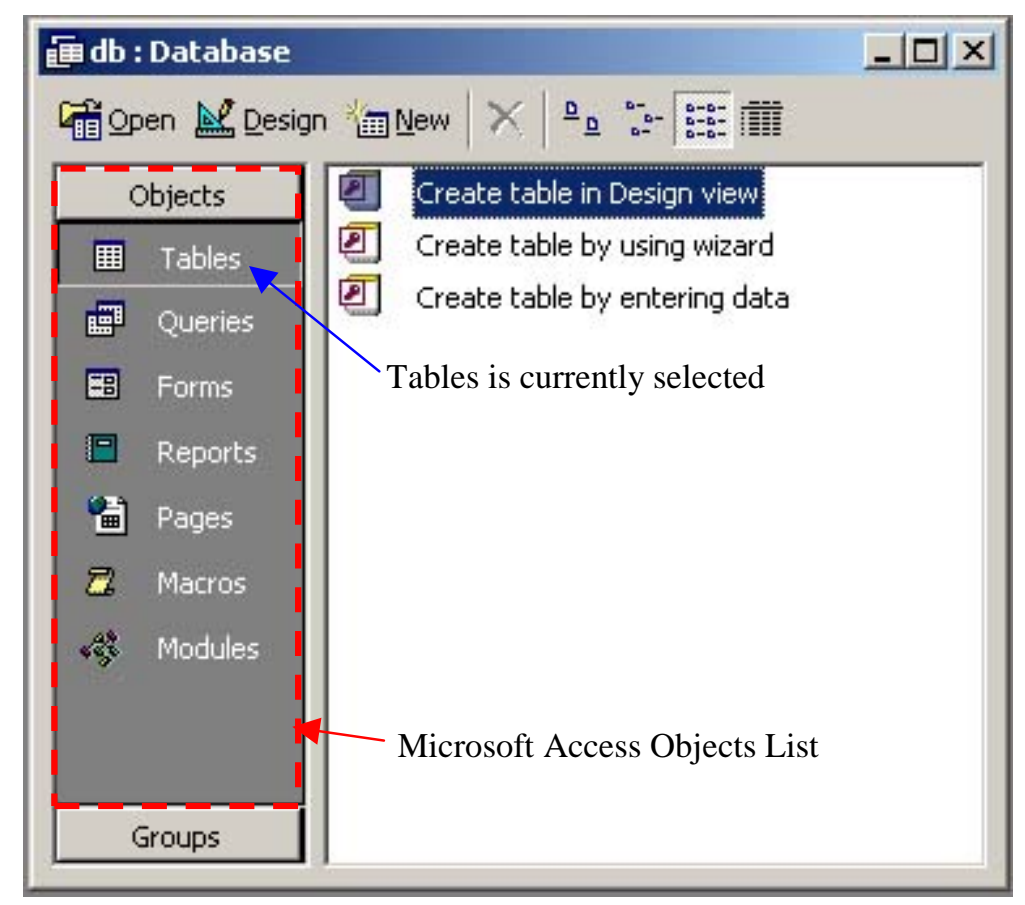

Figure 3.1 Microsoft Access Database Window

Tables are organized in columns and rows (see Figure 3.2). Rows represent records, and columns are fields of information. To change between records use the navigation buttons indicated in the bottom left of the image or simply click the mouse over the desired field and record. Fields are given a definite data type, such as Text, Number, Memo, Date, Currency, AutoNumber, Yes/No, etc. A primary key can be established for each table. This key is used to uniquely identify each record stored in the table. Using a common field in two tables allows bringing the data together from the two tables for viewing, editing, or printing. The datasheet view, seen in Figure 3.2, can be used to add, edit, view, or otherwise work with the data in a table, just by clicking and typing in it. 


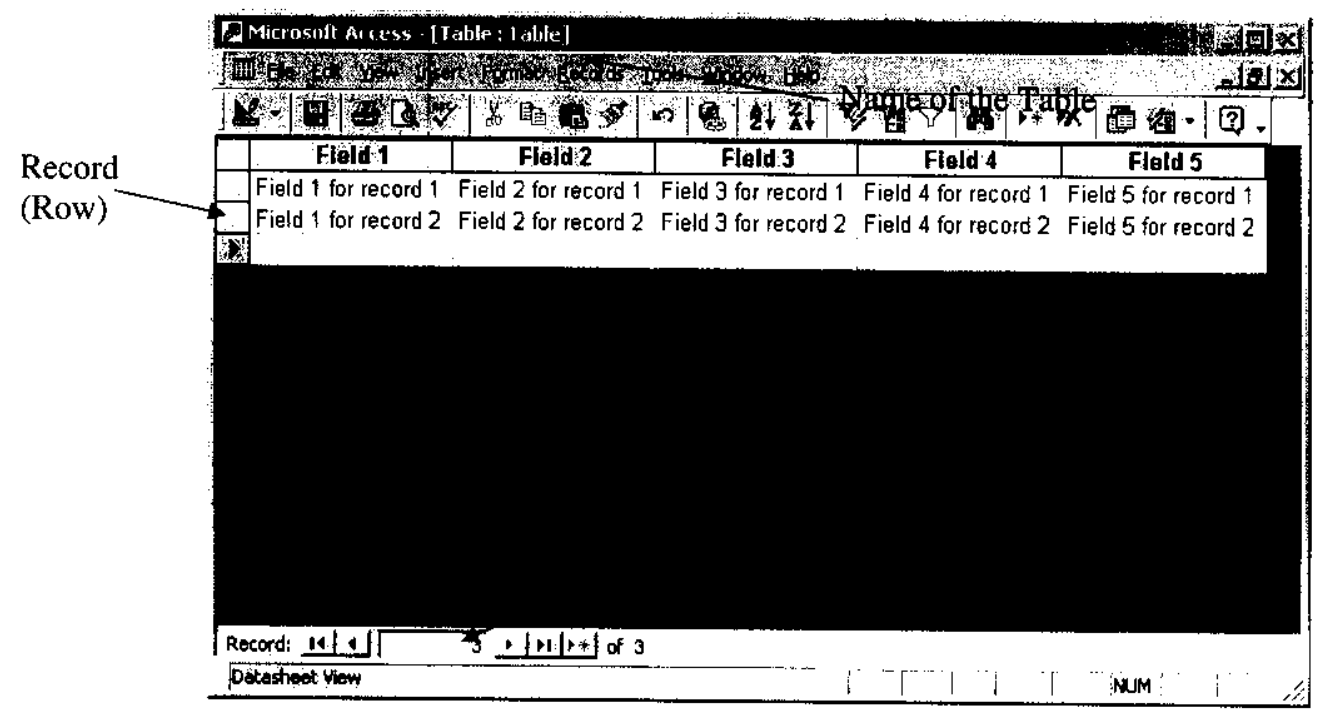

Figure 3.2 Microsoft Access Table Datasheet View

Queries are used to view, change, and analyze data in different ways. They can also be used as the source of records for forms, reports, and data access pages. Within queries, counting, sorting, and calculations can be performed. There are six types of queries: select, cross-tab, append, delete, update and make table. A select query gets data from one or more tables by using specified criteria and then displays it in the order wanted. A cross-tab query displays summarized values, either as sums, counts, or averages, from one field in a table, and arranges them by a group of additional fields listed on the left side and another group listed across the top of the table. The remaining four types perform the action their name suggests.

Queries are shown in a window similar to the table, a datasheet view as seen in Figure 3.3. In this example, a select query is shown. Four fields from two different tables are shown: Field5, Field2 and Field4 are from the table shown in Figure 3.2, and the first column, a field from another table. However, these fields are in a different order and a field from another table is presented. With this example we try to explain the use of a 
select query, where we can obtain any field in any order from tables that are linked with each other. This allows to manipulate the information or to view different information simultaneously.

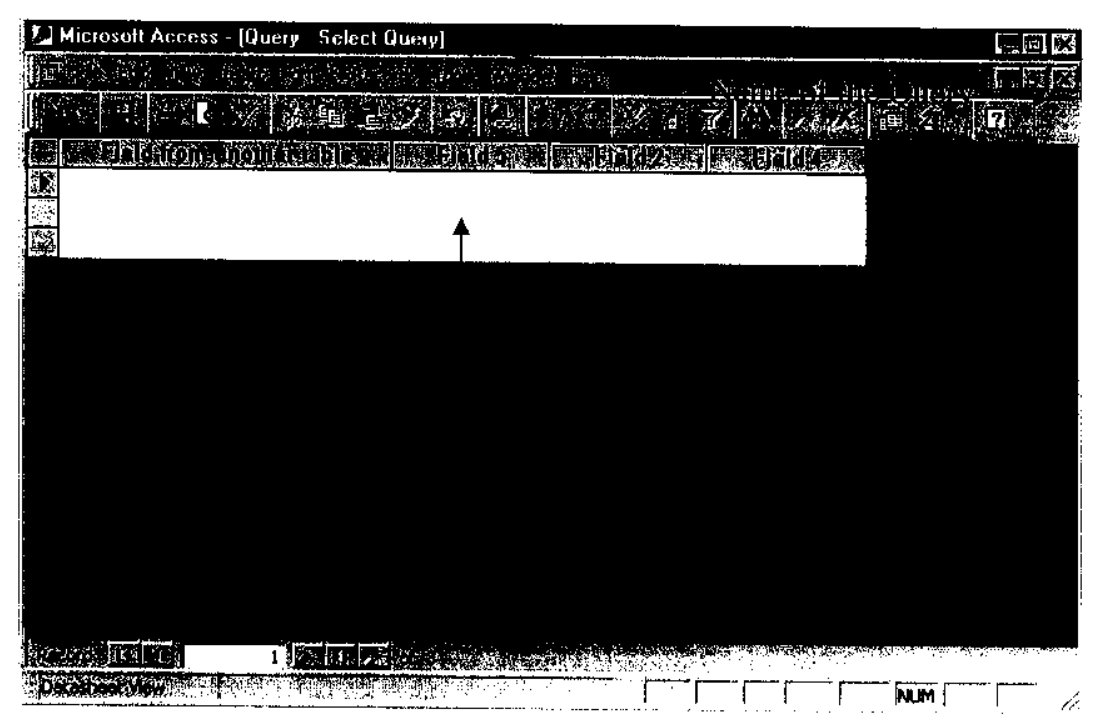

Figure 3.3 Microsoft Access Query Datasheet View

Relationships tell Access how to bring information together. A relationship works by matching data in fields. The program usually takes fields with the same name in both tables. In most cases, these matching fields are the primary key from one table, and a foreign key in the other table. A foreign key is defined as a field that matches the primary key of another table.

Three types of relationships can be established in Access. A one to one relationship is where each record in Table 1 can have only one corresponding record in Table 2, and each record in Table 2 can have only one corresponding record in Table 1. This relationship is used to split a table with many fields, to separate part of a table for security, or to store information that applies only to a part of the main table. A one-tomany relationship is where a record in Table 1 can have many corresponding records in 
Table 2, but a record in Table 2 has only one corresponding record in Table 1 . This relationship is commonly used to reduce the data stored in a table, making the size of the information smaller reducing repetitive data. A many-to-many relationship is where a record in Table 1 can have many corresponding records in Table 2, and a record in Table 2 can have many corresponding records in Table 1 . This relationship is really two one-tomany relationships with a third table. (Microsoft, 1999)

With the use of this database system new records can be added, data can be added or modified, and new fields can be added at any time just by selecting a field on a record an typing on it.

\subsection{Database structure}

The filename of the database is SPR2466.mdb and it is attached to this report as an electronic media. The database is divided in a series of tables that store the information, forms that help visualization and input of data and a number of queries and reports that help analyze the data.

The database stores the following information for each case history analyzed: Type of Retaining Device; Geometry: Dimensions (height, length, etc.), location; Soil conditions: Foundation, backfill; Experience and Performance (Service: Deformations during and after construction; Construction: Material used, construction process, problems; Durability: Maintenance records, type and cost; Economy: Construction and maintenance cost; Other issues: special considerations, noise levels, etc.) 


\subsection{Tables}

Two types of tables are developed: (1) Case History Reviews (CHR), stores important data from different case histories and sources; (2) Tables of support, support the CHR tables with different types of relationships.

Three CHR tables are created: Literature, INDOT Database, and Indiana. The table CHR: Literature stores information from selected cases reported in the literature. The table CHR: INDOT Database stores cost information from INDOT from reported projects in the last five years in the State of Indiana. The table CHR: Indiana stores information from projects obtained from a survey to local contractors and designers, and representative cases further investigated from the INDOT's database.

The CHR tables, through "lookups", are linked with the information stored in the support tables. A lookup displays a list of values looked up from an existing table or query. The main purpose of the support tables is to eliminate data redundancy and data entry inconsistencies, providing customary choices for a series of fields in the CHR tables.

\subsubsection{Case History Review: Literature}

An extensive literature review has been performed. A total of ninety (90) cases have been analyzed. The cases are obtained from journals, conference procedures and other technical publications. The table Case History Review: Literature (CHRL) stores the information that results from the literature search. Table 3.1 shows the fields of the table, their data type, their lookups, and their documented description. The columns in Table 3.1 show the name of the field; the data type of the field; the lookup of the field; and the description of the field documented in the database. With the lookup, at the time of input 
the customized choices from the support table are shown. This makes it easier to correlate cases since it narrows down the quantity of options. The support tables are explained in Section 3.4.4. Fields without a lookup reference are only limited by data type. For instance, fields with a data type of memo allow lengthy descriptions, since they do not have a size limit.

Table 3.1 Field Description of Case History Review: Literature

\begin{tabular}{|c|c|c|c|}
\hline Field & Data Type & Lookup & Description \\
\hline ID_Case & AutoNumber & & Primary Key \\
\hline Name & Text & & Case Name \\
\hline Loc & Number & $\begin{array}{l}\text { Types: } \\
\text { Locations }\end{array}$ & Location (State/Province/Country) \\
\hline Type & Number & $\begin{array}{l}\text { Types: } \\
\text { Retaining } \\
\text { Structure }\end{array}$ & Retaining Wall Type \\
\hline Support & Number & $\begin{array}{l}\text { Types: } \\
\text { Additional } \\
\text { Support }\end{array}$ & Additional Support \\
\hline Height & Number & & Height of wall \\
\hline Length & Number & & Length of wall \\
\hline $\mathrm{BF} / \mathrm{SS}$ & Number & Types: Soil & Backfill/Site Subsoil \\
\hline Found & Number & Types: Soil & Foundation Subsoil \\
\hline Status & Number & $\begin{array}{l}\text { Types: Walls' } \\
\text { Status }\end{array}$ & Status of the wall (Serviceability) \\
\hline Title & Text & & Title of Article 1 \\
\hline Author & Text & & Author of the Article 1 \\
\hline Ref & Number & $\begin{array}{l}\text { Books: } \\
\text { References }\end{array}$ & Book Reference 1 \\
\hline Pages & Text & & Page numbers 1 \\
\hline Title2 & Text & & Title of Article 2 \\
\hline Author2 & Text & & Author of the Article 2 \\
\hline Ref2 & Number & $\begin{array}{l}\text { Books: } \\
\text { References }\end{array}$ & Book Reference 2 \\
\hline Pages2 & Text & & Page numbers 2 \\
\hline Descrip & Memo & & Project Description \\
\hline SubCon & Memo & & Subsurface Conditions \\
\hline Sdesc & Number & $\begin{array}{l}\text { Types: Soil - } \\
\text { Description }\end{array}$ & Origin of Subsoil Observations \\
\hline
\end{tabular}


Table 3.1 Field Description of Case History Review: Literature (Cont'd)

\begin{tabular}{|l|l|l|l|}
\hline Field & Data Type & Lookup & Description \\
\hline ExpPer & Memo & & Experience \& Performance \\
\hline Reminder & Memo & & Key points of case \\
\hline Abstract & Memo & & $\begin{array}{l}\text { Abstract of Article or Introduction if } \\
\text { Abstract is not present }\end{array}$ \\
\hline
\end{tabular}

For all 90 cases, each of the fields of the table is filled with the information found in the literature. Therefore, all the important factors, as described in Section 3.3, regarding each of the analyzed cases can be easily accessed. The field ID_Case is the primary key of the table and stores the case id number; Name stores the name of the project; Loc stores the location of the project; Type stores the type of retaining structure; Support stores the type of additional support given to the device by means of tieback, bracing, etc.; the fields Height and Length have the respective maximum dimensions in meters of the device if available; BF/SS stores the backfill or subsoil information whichever applies; Found stores the information of the soil of the foundation; Status has information regarding the status (failed, in service, etc.) of the wall; the fields Title, Author, Ref, Pages, Title2, Author2, Ref2, and Pages2 have the literature reference information; Descrip has a small description of the project; SubCon has a small description of the subsurface conditions of the site; Sdesc indicates the basis of strength soil descriptions (author's description, data, etc.); ExpPer stores information regarding the experience and performance of the wall as described in Section 3.3; Reminder has small comments regarding the case; and Abstract stores the abstract of the article of the case history.

The cases analyzed are listed in Table 3.2. The cases listed are accompanied by some of the fields of the database as described previously. The columns shown correspond to the 
following fields: ID_Case, Name, Type, Support, Height (if available), and Author. This listing is created with the report: "Report Table: Listing of Case History Review: Literature".

Table 3.2 Listing of Case History Review: Literature

\begin{tabular}{|l|l|l|l|r|l|}
\hline ID & Name & Type & Support & H (m) & Reference \\
\hline 1 & Lake Parkway & Soldier Piles & $\begin{array}{l}\text { Soil } \\
\text { Improvement } \\
\text { and Tieback }\end{array}$ & 7.6 & $\begin{array}{l}\text { Thomas C. } \\
\text { Anderson }\end{array}$ \\
\hline 2 & Davison Freeway & Soldier Piles & Tieback & 6.0 & Harry Schnabel \\
\hline 3 & $\begin{array}{l}\text { Geysers Geothermal } \\
\text { Power Plant }\end{array}$ & Cast in-situ & Tieback & 7.6 & $\begin{array}{l}\text { John Hovland and } \\
\text { Donald F. } \\
\text { Willoughby }\end{array}$ \\
\hline 4 & $\begin{array}{l}\text { 4th Rocky Fill, Main } \\
\text { Line Clinchfield } \\
\text { Railroad }\end{array}$ & Soldier Piles & Tieback & 12.2 & G. L. Tysinger \\
\hline 5 & $\begin{array}{l}\text { Edmonton } \\
\text { Convention Center }\end{array}$ & Cast in-situ & Tieback & 19.8 & $\begin{array}{l}\text { Lawerence A. } \\
\text { Balanko, Norbert } \\
\text { Morgenstern, Rudy } \\
\text { Yacyshyn }\end{array}$ \\
\hline 6 & $\begin{array}{l}\text { South Approach to } \\
\text { Third Harbor } \\
\text { Tunnel, Boston }\end{array}$ & Sheet Piles & Tieback & 19.0 & $\begin{array}{l}\text { David Cacoilo, } \\
\text { George Tamaro } \\
\text { and Peter Edinger }\end{array}$ \\
\hline 7 & $\begin{array}{l}\text { Pilot House } \\
\text { Extension, Boston }\end{array}$ & Cast in-situ & Braced & 10.7 & $\begin{array}{l}\text { Minhaj Kirmani, } \\
\text { Steve Highfill, } \\
\text { Jimmy Xu }\end{array}$ \\
\hline 8 & $\begin{array}{l}\text { Research by } \\
\text { Northeastern } \\
\text { University, Boston }\end{array}$ & Soil Nailing & $\begin{array}{l}\text { No } \\
\text { Additional } \\
\text { Support }\end{array}$ & 3.5 & $\begin{array}{l}\text { Tolga Oral and } \\
\text { Thomas C. } \\
\text { Sheahan }\end{array}$ \\
\hline 9 & $\begin{array}{l}\text { Main line tunnel at } \\
\text { Bird Island Flats, I- } \\
90, \text { Boston }\end{array}$ & Soil-Cement & $\begin{array}{l}\text { Soil } \\
\text { Improvement } \\
\text { and Tieback }\end{array}$ & 19.4 & $\begin{array}{l}\text { T. D. O'Rourke; A. } \\
\text { J. McGinn; J. } \\
\text { Dewsnap; and H. } \\
\text { E. Stewart }\end{array}$ \\
\hline 10 & $\begin{array}{l}\text { Empress Dock, } \\
\text { Southampton }\end{array}$ & Concrete & $\begin{array}{l}\text { No } \\
\text { Additional } \\
\text { Support }\end{array}$ & 15.7 & $\begin{array}{l}\text { Civil Engineering } \\
\text { codes of practice } \\
\text { joint committee }\end{array}$ \\
\hline 11 & $\begin{array}{l}\text { The Kidderpur } \\
\text { Docks, Calcutta } \\
\text { Support }\end{array}$ & Masonry & 14.0 & $\begin{array}{l}\text { Civil Engineering } \\
\text { codes of practice } \\
\text { joint committee }\end{array}$ \\
\hline
\end{tabular}


Table 3.2 Listing of Case History Review: Literature (Cont'd)

\begin{tabular}{|l|l|l|l|r|l|}
\hline ID & Name & Type & Support & H (m) & Reference \\
\hline 12 & $\begin{array}{l}\text { Calata di Ponente, } \\
\text { Venice }\end{array}$ & Concrete & $\begin{array}{l}\text { No } \\
\text { Additional } \\
\text { Support }\end{array}$ & 10.7 & $\begin{array}{l}\text { Civil Engineering } \\
\text { codes of practice } \\
\text { joint committee }\end{array}$ \\
\hline 13 & $\begin{array}{l}\text { East India Docks, } \\
\text { London }\end{array}$ & Masonry & $\begin{array}{l}\text { No } \\
\text { Additional } \\
\text { Support }\end{array}$ & 10.7 & $\begin{array}{l}\text { Civil Engineering } \\
\text { codes of practice } \\
\text { joint committee }\end{array}$ \\
\hline 14 & $\begin{array}{l}\text { Retaining wall at } \\
\text { Baghdad }\end{array}$ & Masonry & $\begin{array}{l}\text { No } \\
\text { Additional } \\
\text { Support }\end{array}$ & 14.5 & $\begin{array}{l}\text { Civil Engineering } \\
\text { codes of practice } \\
\text { joint committee }\end{array}$ \\
\hline 15 & $\begin{array}{l}\text { Wembley Hill } \\
\text { Station (Great } \\
\text { Central Railway), } \\
\text { London }\end{array}$ & Masonry & $\begin{array}{l}\text { No } \\
\text { Additional } \\
\text { Support }\end{array}$ & 9.5 & $\begin{array}{l}\text { Civil Engineering } \\
\text { codes of practice } \\
\text { joint committee }\end{array}$ \\
\hline 16 & $\begin{array}{l}\text { Park Village East, } \\
\text { Euston Station, } \\
\text { London }\end{array}$ & Concrete & $\begin{array}{l}\text { No } \\
\text { Additional } \\
\text { Support }\end{array}$ & 17.5 & $\begin{array}{l}\text { Civil Engineering } \\
\text { codes of practice } \\
\text { joint committee }\end{array}$ \\
\hline 17 & $\begin{array}{l}\text { Kensal Green, LMS, } \\
\text { London }\end{array}$ & Concrete & $\begin{array}{l}\text { No } \\
\text { Additional } \\
\text { Support }\end{array}$ & 5.2 & $\begin{array}{l}\text { Civil Engineering } \\
\text { codes of practice } \\
\text { joint committee }\end{array}$ \\
\hline 18 & $\begin{array}{l}\text { Mill Lane wall, } \\
\text { Cricklewood, } \\
\text { London }\end{array}$ & Concrete & $\begin{array}{l}\text { No } \\
\text { Additional } \\
\text { Support }\end{array}$ & 9.1 & $\begin{array}{l}\text { Civil Engineering } \\
\text { codes of practice } \\
\text { joint committee }\end{array}$ \\
\hline 19 & $\begin{array}{l}\text { Graving Dock, } \\
\text { Naples }\end{array}$ & Concrete & $\begin{array}{l}\text { No } \\
\text { Additional } \\
\text { Support }\end{array}$ & 12.2 & $\begin{array}{l}\text { Civil Engineering } \\
\text { codes of practice } \\
\text { joint committee }\end{array}$ \\
\hline 20 & $\begin{array}{l}\text { Ramp D Fort Point } \\
\text { Channel Crossing, } \\
\text { Boston }\end{array}$ & Cast in-situ & $\begin{array}{l}\text { Soil } \\
\text { Improvement } \\
\text { and Braced }\end{array}$ & 15.0 & $\begin{array}{l}\text { James R. } \\
\text { Lambrechts, Paul } \\
\text { A. Roy \& Eric J. } \\
\text { Wishart }\end{array}$ \\
\hline 21 & $\begin{array}{l}\text { Taiwan Power } \\
\text { Company high-rise } \\
\text { Tacice complex, } \\
\text { Taipei City }\end{array}$ & $\begin{array}{l}\text { Taipei Northern } \\
\text { Area Electricity } \\
\text { Distribution Center, } \\
\text { Zone A }\end{array}$ & Sheet Piles & $\begin{array}{l}\text { Braced } \\
\text { Song }\end{array}$ \\
\hline
\end{tabular}


Table 3.2 Listing of Case History Review: Literature (Cont'd)

\begin{tabular}{|c|c|c|c|c|c|}
\hline ID & Name & Type & Support & H (m) & Reference \\
\hline 23 & $\begin{array}{l}\text { Taipei Northern } \\
\text { Area Electricity } \\
\text { Distribution Center, } \\
\text { Zone B }\end{array}$ & Cast in-situ & $\begin{array}{l}\text { Soil } \\
\text { Improvement } \\
\text { and Braced }\end{array}$ & 7.8 & $\begin{array}{l}\text { Z. C. Moh; T. F. } \\
\text { Song }\end{array}$ \\
\hline 24 & $\begin{array}{l}\text { Charles Center } \\
\text { Station, Baltimore } \\
\text { Metro }\end{array}$ & Cast in-situ & Braced & 20.0 & $\begin{array}{l}\text { E. J. Zeigler; J. L. } \\
\text { Wirth; J. T. Miller }\end{array}$ \\
\hline 25 & $\begin{array}{l}\text { Canadian National } \\
\text { Railway Richmond } \\
\text { Hill Gravity Wall }\end{array}$ & $\begin{array}{l}\text { Mechanically } \\
\text { Stabilized } \\
\text { Earth }\end{array}$ & $\begin{array}{l}\text { No } \\
\text { Additional } \\
\text { Support }\end{array}$ & 3.0 & $\begin{array}{l}\text { R. J. Bathurst; R. } \\
\text { E. Crowe }\end{array}$ \\
\hline 26 & $\begin{array}{l}\text { Condominium road } \\
\text { embankment, } \\
\text { Cambridge }\end{array}$ & $\begin{array}{l}\text { Mechanically } \\
\text { Stabilized } \\
\text { Earth }\end{array}$ & $\begin{array}{l}\text { No } \\
\text { Additional } \\
\text { Support }\end{array}$ & 7.3 & $\begin{array}{l}\text { R. J. Bathurst; R. } \\
\text { E. Crowe }\end{array}$ \\
\hline 27 & $\begin{array}{l}\text { FHWA Research } \\
\text { Wall 1 - Precast } \\
\text { Concrete \& Metal } \\
\text { Strips }\end{array}$ & $\begin{array}{l}\text { Mechanically } \\
\text { Stabilized } \\
\text { Earth }\end{array}$ & $\begin{array}{l}\text { No } \\
\text { Additional } \\
\text { Support }\end{array}$ & 6.1 & $\begin{array}{l}\text { Barry R. } \\
\text { Christopher; } \\
\text { Cynthia } \\
\text { Bonczkiewicz; } \\
\text { Robert D. Holtz }\end{array}$ \\
\hline 28 & $\begin{array}{l}\text { FHWA Research } \\
\text { Wall } 2 \text { - Precast } \\
\text { Concrete \& } \\
\text { Extruded Geogrid }\end{array}$ & $\begin{array}{l}\text { Mechanically } \\
\text { Stabilized } \\
\text { Earth }\end{array}$ & $\begin{array}{l}\text { No } \\
\text { Additional } \\
\text { Support }\end{array}$ & 6.1 & $\begin{array}{l}\text { Barry R. } \\
\text { Christopher; } \\
\text { Cynthia } \\
\text { Bonczkiewicz; } \\
\text { Robert D. Holtz }\end{array}$ \\
\hline 29 & $\begin{array}{l}\text { FHWA Research } \\
\text { Wall } 3 \text { - Precast } \\
\text { Concrete \& Bar Mat } \\
\text { (Granular backfill) }\end{array}$ & $\begin{array}{l}\text { Mechanically } \\
\text { Stabilized } \\
\text { Earth }\end{array}$ & $\begin{array}{l}\text { No } \\
\text { Additional } \\
\text { Support }\end{array}$ & 6.1 & $\begin{array}{l}\text { Barry R. } \\
\text { Christopher; } \\
\text { Cynthia } \\
\text { Bonczkiewicz; } \\
\text { Robert D. Holtz }\end{array}$ \\
\hline 30 & $\begin{array}{l}\text { FHWA Research } \\
\text { Wall } 4 \text { - Precast } \\
\text { Concrete \& Bar Mat } \\
\text { (Cobble backfill) }\end{array}$ & $\begin{array}{l}\text { Mechanically } \\
\text { Stabilized } \\
\text { Earth }\end{array}$ & $\begin{array}{l}\text { No } \\
\text { Additional } \\
\text { Support }\end{array}$ & 6.1 & $\begin{array}{l}\text { Barry R. } \\
\text { Christopher; } \\
\text { Cynthia } \\
\text { Bonczkiewicz; } \\
\text { Robert D. Holtz }\end{array}$ \\
\hline 31 & $\begin{array}{l}\text { FHWA Research } \\
\text { Wall } 5 \text { - Precast } \\
\text { Concrete \& Bar Mat } \\
\text { (Silt backfill) }\end{array}$ & $\begin{array}{l}\text { Mechanically } \\
\text { Stabilized } \\
\text { Earth }\end{array}$ & $\begin{array}{l}\text { No } \\
\text { Additional } \\
\text { Support }\end{array}$ & 6.1 & $\begin{array}{l}\text { Barry R. } \\
\text { Christopher; } \\
\text { Cynthia } \\
\text { Bonczkiewicz; } \\
\text { Robert D. Holtz }\end{array}$ \\
\hline
\end{tabular}


Table 3.2 Listing of Case History Review: Literature (Cont'd)

\begin{tabular}{|c|c|c|c|c|c|}
\hline ID & Name & Type & Support & $\mathbf{H}(\mathbf{m})$ & Reference \\
\hline 32 & $\begin{array}{l}\text { FHWA Research } \\
\text { Wall } 6 \text { - Wrapped } \\
\text { Nonwoven } \\
\text { Geotextile }\end{array}$ & $\begin{array}{l}\text { Mechanically } \\
\text { Stabilized } \\
\text { Earth }\end{array}$ & $\begin{array}{l}\text { No } \\
\text { Additional } \\
\text { Support }\end{array}$ & 5.9 & $\begin{array}{l}\text { Barry R. } \\
\text { Christopher; } \\
\text { Cynthia } \\
\text { Bonczkiewicz; } \\
\text { Robert D. Holtz }\end{array}$ \\
\hline 33 & $\begin{array}{l}\text { FHWA Research } \\
\text { Wall } 7 \text { - Tailed } \\
\text { Gabion (1) }\end{array}$ & $\begin{array}{l}\text { Tailed } \\
\text { gabions }\end{array}$ & $\begin{array}{l}\text { No } \\
\text { Additional } \\
\text { Support }\end{array}$ & 6.4 & $\begin{array}{l}\text { Barry R. } \\
\text { Christopher; } \\
\text { Cynthia } \\
\text { Bonczkiewicz; } \\
\text { Robert D. Holtz }\end{array}$ \\
\hline 34 & $\begin{array}{l}\text { FHWA Research } \\
\text { Wall } 8 \text { - Tailed } \\
\text { Gabion (2) }\end{array}$ & \begin{tabular}{|l|} 
Tailed \\
gabions
\end{tabular} & $\begin{array}{l}\text { No } \\
\text { Additional } \\
\text { Support }\end{array}$ & 6.4 & $\begin{array}{l}\text { Barry R. } \\
\text { Christopher; } \\
\text { Cynthia } \\
\text { Bonczkiewicz; } \\
\text { Robert D. Holtz }\end{array}$ \\
\hline 35 & A15 motorway & $\begin{array}{l}\text { Mechanically } \\
\text { Stabilized } \\
\text { Earth }\end{array}$ & $\begin{array}{l}\text { No } \\
\text { Additional } \\
\text { Support }\end{array}$ & 4.0 & $\begin{array}{l}\text { J. P. Gourc; Y. } \\
\text { Matichard }\end{array}$ \\
\hline 36 & $\begin{array}{l}\text { Car park, Prapoutel, } \\
\text { Grenoble }\end{array}$ & \begin{tabular}{|l} 
Mechanically \\
Stabilized \\
Earth
\end{tabular} & $\begin{array}{l}\text { No } \\
\text { Additional } \\
\text { Support }\end{array}$ & 10.0 & $\begin{array}{l}\text { J. P. Gourc; Y. } \\
\text { Matichard }\end{array}$ \\
\hline 37 & $\begin{array}{l}\text { Mountain road, } \\
\text { Allevard, Grenoble }\end{array}$ & \begin{tabular}{|l|} 
Mechanically \\
Stabilized \\
Earth \\
\end{tabular} & $\begin{array}{l}\text { No } \\
\text { Additional } \\
\text { Support }\end{array}$ & 3.0 & $\begin{array}{l}\text { J. P. Gourc; Y. } \\
\text { Matichard }\end{array}$ \\
\hline 38 & $\begin{array}{l}\text { Mountain road, } \\
\text { Pellafol, Grenoble }\end{array}$ & \begin{tabular}{|l|} 
Mechanically \\
Stabilized \\
Earth
\end{tabular} & $\begin{array}{l}\text { No } \\
\text { Additional } \\
\text { Support }\end{array}$ & 4.2 & $\begin{array}{l}\text { J. P. Gourc; Y. } \\
\text { Matichard }\end{array}$ \\
\hline 39 & $\begin{array}{l}\text { Widening of the } \\
\text { crest of road } \\
\text { embankment, La } \\
\text { Houpette }\end{array}$ & $\begin{array}{l}\text { Mechanically } \\
\text { Stabilized } \\
\text { Earth }\end{array}$ & $\begin{array}{l}\text { No } \\
\text { Additional } \\
\text { Support }\end{array}$ & 1.4 & $\begin{array}{l}\text { J. P. Gourc; Y. } \\
\text { Matichard }\end{array}$ \\
\hline 40 & $\begin{array}{l}\text { Coast road } \\
\text { reconstruction, } \\
\text { Trouville }\end{array}$ & $\begin{array}{l}\text { Mechanically } \\
\text { Stabilized } \\
\text { Earth }\end{array}$ & $\begin{array}{l}\text { No } \\
\text { Additional } \\
\text { Support }\end{array}$ & 6.0 & $\begin{array}{l}\text { J. P. Gourc; Y. } \\
\text { Matichard }\end{array}$ \\
\hline 41 & $\begin{array}{l}\text { 19th Century } \\
\text { retaining wall } \\
\text { reinforcement, } \\
\text { Langres }\end{array}$ & \begin{tabular}{|l} 
Mechanically \\
Stabilized \\
Earth
\end{tabular} & $\begin{array}{l}\text { No } \\
\text { Additional } \\
\text { Support }\end{array}$ & 4.0 & $\begin{array}{l}\text { J. P. Gourc; Y. } \\
\text { Matichard }\end{array}$ \\
\hline
\end{tabular}


Table 3.2 Listing of Case History Review: Literature (Cont'd)

\begin{tabular}{|c|c|c|c|c|c|}
\hline ID & Name & Type & Support & H (m) & Reference \\
\hline 42 & $\begin{array}{l}\text { Nuclear magnetic } \\
\text { resonance imager, } \\
\text { Grenoble Hospital }\end{array}$ & $\begin{array}{l}\text { Mechanically } \\
\text { Stabilized } \\
\text { Earth }\end{array}$ & $\begin{array}{l}\text { No } \\
\text { Additional } \\
\text { Support } \\
\end{array}$ & 5.0 & $\begin{array}{l}\text { J. P. Gourc; Y. } \\
\text { Matichard }\end{array}$ \\
\hline 43 & $\begin{array}{l}\text { Consolidation of } \\
\text { landslide, Lixing- } \\
\text { Nancy }\end{array}$ & $\begin{array}{l}\text { Mechanically } \\
\text { Stabilized } \\
\text { Earth }\end{array}$ & $\begin{array}{l}\text { No } \\
\text { Additional } \\
\text { Support }\end{array}$ & 4.5 & $\begin{array}{l}\text { J. P. Gourc; Y. } \\
\text { Matichard }\end{array}$ \\
\hline 44 & $\begin{array}{l}\text { Road embankment, } \\
\text { Luchon }\end{array}$ & $\begin{array}{l}\text { Mechanically } \\
\text { Stabilized } \\
\text { Earth }\end{array}$ & $\begin{array}{l}\text { No } \\
\text { Additional } \\
\text { Support }\end{array}$ & 5.0 & $\begin{array}{l}\text { J. P. Gourc; Y. } \\
\text { Matichard }\end{array}$ \\
\hline 45 & $\begin{array}{l}\text { Experimental } \\
\text { Structure, Toulouse - } \\
\text { Lezat }\end{array}$ & $\begin{array}{l}\text { Mechanically } \\
\text { Stabilized } \\
\text { Earth }\end{array}$ & $\begin{array}{l}\text { No } \\
\text { Additional } \\
\text { Support }\end{array}$ & 6.0 & $\begin{array}{l}\text { J. P. Gourc; Y. } \\
\text { Matichard }\end{array}$ \\
\hline 46 & $\begin{array}{l}\text { Embankment for } \\
\text { high speed train, } \\
\text { Vienne }\end{array}$ & $\begin{array}{l}\text { Mechanically } \\
\text { Stabilized } \\
\text { Earth }\end{array}$ & $\begin{array}{l}\text { No } \\
\text { Additional } \\
\text { Support }\end{array}$ & 3.4 & $\begin{array}{l}\text { J. P. Gourc; Y. } \\
\text { Matichard }\end{array}$ \\
\hline 47 & $\begin{array}{l}\text { Site of } 1992 \text { Winter } \\
\text { Olympic Games, } \\
\text { Brides les Bains }\end{array}$ & $\begin{array}{l}\text { Mechanically } \\
\text { Stabilized } \\
\text { Earth }\end{array}$ & $\begin{array}{l}\text { No } \\
\text { Additional } \\
\text { Support } \\
\end{array}$ & 10.0 & $\begin{array}{l}\text { J. P. Gourc; Y. } \\
\text { Matichard }\end{array}$ \\
\hline 48 & $\begin{array}{l}\text { Retaining walls of } \\
\text { CD4 road, La } \\
\text { Valentine }\end{array}$ & $\begin{array}{l}\text { Mechanically } \\
\text { Stabilized } \\
\text { Earth }\end{array}$ & $\begin{array}{l}\text { No } \\
\text { Additional } \\
\text { Support }\end{array}$ & 4.0 & $\begin{array}{l}\text { J. P. Gourc; Y. } \\
\text { Matichard }\end{array}$ \\
\hline 49 & $\begin{array}{l}\text { Gaspe Peninsula } \\
\text { Reinforced Soil } \\
\text { Seawall }\end{array}$ & $\begin{array}{l}\text { Mechanically } \\
\text { Stabilized } \\
\text { Earth }\end{array}$ & $\begin{array}{l}\text { No } \\
\text { Additional } \\
\text { Support }\end{array}$ & 5.3 & $\begin{array}{l}\text { J. G. Collin; R. R. } \\
\text { Berg }\end{array}$ \\
\hline 50 & $\begin{array}{l}\text { Tanque Verde } \\
\text { Reinforced Soil } \\
\text { Wall, Tucson }\end{array}$ & $\begin{array}{l}\text { Mechanically } \\
\text { Stabilized } \\
\text { Earth }\end{array}$ & $\begin{array}{l}\text { No } \\
\text { Additional } \\
\text { Support }\end{array}$ & 6.6 & $\begin{array}{l}\text { J. G. Collin; R. R. } \\
\text { Berg }\end{array}$ \\
\hline 51 & $\begin{array}{l}\text { Illinois Tollway - } \\
\text { Genesis Reinforced } \\
\text { Soil Wall }\end{array}$ & $\begin{array}{l}\text { Mechanically } \\
\text { Stabilized } \\
\text { Earth }\end{array}$ & $\begin{array}{l}\text { No } \\
\text { Additional } \\
\text { Support }\end{array}$ & 9.0 & $\begin{array}{l}\text { J. G. Collin; R. R. } \\
\text { Berg }\end{array}$ \\
\hline 52 & $\begin{array}{l}\text { Bullet Train yard, } \\
\text { Nagoya }\end{array}$ & $\begin{array}{l}\text { Mechanically } \\
\text { Stabilized } \\
\text { Earth }\end{array}$ & $\begin{array}{l}\text { No } \\
\text { Additional } \\
\text { Support }\end{array}$ & 5.6 & $\begin{array}{l}\text { M. Tateyama; O. } \\
\text { Murata; K. } \\
\text { Watanabe; F. } \\
\text { Tatsuoka } \\
\end{array}$ \\
\hline 53 & $\begin{array}{l}\text { Glenwood Canyon } \\
\text { Test Wall }\end{array}$ & $\begin{array}{l}\text { Mechanically } \\
\text { Stabilized } \\
\text { Earth }\end{array}$ & $\begin{array}{l}\text { No } \\
\text { Additional } \\
\text { Support }\end{array}$ & 4.6 & $\begin{array}{l}\text { Jonathan T. H. } \\
\text { Wu; Robert K. } \\
\text { Barret; Nelson N. } \\
\text { S. Chou }\end{array}$ \\
\hline
\end{tabular}


Table 3.2 Listing of Case History Review: Literature (Cont'd)

\begin{tabular}{|c|c|c|c|c|c|}
\hline ID & Name & Type & Support & $\mathbf{H}(\mathbf{m})$ & Reference \\
\hline 54 & $\begin{array}{l}\text { Highway } 13 \text { North } \\
\text { of Craig }\end{array}$ & $\begin{array}{l}\text { Mechanically } \\
\text { Stabilized } \\
\text { Earth }\end{array}$ & $\begin{array}{l}\text { No } \\
\text { Additional } \\
\text { Support }\end{array}$ & 2.1 & $\begin{array}{l}\text { Jonathan T. H. } \\
\text { Wu; Robert K. } \\
\text { Barret; Nelson N. } \\
\text { S. Chou }\end{array}$ \\
\hline 55 & $\begin{array}{l}\text { Junction of } \\
\text { Highways } 67 \text { and } \\
96, \text { Wetmore }\end{array}$ & $\begin{array}{l}\text { Mechanically } \\
\text { Stabilized } \\
\text { Earth }\end{array}$ & $\begin{array}{l}\text { No } \\
\text { Additional } \\
\text { Support }\end{array}$ & 4.3 & $\begin{array}{l}\text { Jonathan T. H. } \\
\text { Wu; Robert K. } \\
\text { Barret; Nelson N. } \\
\text { S. Chou }\end{array}$ \\
\hline 56 & Highway 43, Wray & $\begin{array}{l}\text { Mechanically } \\
\text { Stabilized } \\
\text { Earth }\end{array}$ & $\begin{array}{l}\text { No } \\
\text { Additional } \\
\text { Support }\end{array}$ & 2.1 & $\begin{array}{l}\text { Jonathan T. H. } \\
\text { Wu; Robert K. } \\
\text { Barret; Nelson N. } \\
\text { S. Chou }\end{array}$ \\
\hline 57 & $\begin{array}{l}\text { Interstate } 25, \\
\text { Colorado Springs }\end{array}$ & $\begin{array}{l}\text { Mechanically } \\
\text { Stabilized } \\
\text { Earth }\end{array}$ & $\begin{array}{l}\text { No } \\
\text { Additional } \\
\text { Support }\end{array}$ & 4.9 & $\begin{array}{l}\text { Jonathan T. H. } \\
\text { Wu; Robert K. } \\
\text { Barret; Nelson N. } \\
\text { S. Chou }\end{array}$ \\
\hline 58 & $\begin{array}{l}\text { Railway } \\
\text { Embankment } \\
\text { Reconstruction, } \\
\text { Kyoto }\end{array}$ & $\begin{array}{l}\text { Mechanically } \\
\text { Stabilized } \\
\text { Earth }\end{array}$ & $\begin{array}{l}\text { Soil } \\
\text { Improvement } \\
\text { and other }\end{array}$ & 4.8 & $\begin{array}{l}\text { Y. Doi; S. } \\
\text { Mizushima; M. } \\
\text { Tateyama; O. } \\
\text { Murata }\end{array}$ \\
\hline 59 & $\begin{array}{l}\text { Reinforcement } \\
\text { Blocking a Stream }\end{array}$ & $\begin{array}{l}\text { Mechanically } \\
\text { Stabilized } \\
\text { Earth }\end{array}$ & $\begin{array}{l}\text { No } \\
\text { Additional } \\
\text { Support }\end{array}$ & 10.0 & $\begin{array}{l}\text { Ching-Chuan } \\
\text { Huang }\end{array}$ \\
\hline 60 & $\begin{array}{l}\text { Insufficient } \\
\text { reinforcement length } \\
\text { for saturated } \\
\text { conditions }\end{array}$ & $\begin{array}{l}\text { Mechanically } \\
\text { Stabilized } \\
\text { Earth }\end{array}$ & $\begin{array}{l}\text { No } \\
\text { Additional } \\
\text { Support }\end{array}$ & 8.0 & $\begin{array}{l}\text { Ching-Chuan } \\
\text { Huang }\end{array}$ \\
\hline 61 & $\begin{array}{l}\text { Reinforcement } \\
\text { breakage }\end{array}$ & $\begin{array}{l}\text { Mechanically } \\
\text { Stabilized } \\
\text { Earth }\end{array}$ & $\begin{array}{l}\text { No } \\
\text { Additional } \\
\text { Support } \\
\end{array}$ & 10.0 & $\begin{array}{l}\text { Ching-Chuan } \\
\text { Huang }\end{array}$ \\
\hline 62 & $\begin{array}{l}\text { GRS retaining walls } \\
\text { for railway } \\
\text { embankment } \\
\text { reconstruction, } \\
\text { Amagasaki }\end{array}$ & $\begin{array}{l}\text { Mechanically } \\
\text { Stabilized } \\
\text { Earth }\end{array}$ & $\begin{array}{l}\text { No } \\
\text { Additional } \\
\text { Support }\end{array}$ & 4.9 & $\begin{array}{l}\text { Y. Kanazawa; K } \\
\text { Ikeda; O. Murata; } \\
\text { M. Tateyama; F. } \\
\text { Tatsuoka }\end{array}$ \\
\hline 63 & $\begin{array}{l}\text { GRS retaining walls } \\
\text { for abutments }\end{array}$ & $\begin{array}{l}\text { Mechanically } \\
\text { Stabilized } \\
\text { Earth }\end{array}$ & $\begin{array}{l}\text { No } \\
\text { Additional } \\
\text { Support }\end{array}$ & 2.7 & $\begin{array}{l}\text { Y. Kanazawa; K } \\
\text { Ikeda; O. Murata; } \\
\text { M. Tateyama; F. } \\
\text { Tatsuoka }\end{array}$ \\
\hline
\end{tabular}


Table 3.2 Listing of Case History Review: Literature (Cont'd)

\begin{tabular}{|c|c|c|c|c|c|}
\hline ID & Name & \begin{tabular}{|l|} 
Type \\
\end{tabular} & Support & H (m) & Reference \\
\hline 64 & $\begin{array}{l}\text { The Stanford Linear } \\
\text { Collider }\end{array}$ & Soldier Piles & Tieback & 17.0 & Mark N. Obergfell \\
\hline 65 & $\begin{array}{l}\text { Interstate 70, near } \\
\text { Glenwood Canyon }\end{array}$ & Counterfort & $\begin{array}{l}\text { No } \\
\text { Additional } \\
\text { Support }\end{array}$ & 6.5 & $\begin{array}{l}\text { Tzong H. Wu; } \\
\text { Nelson N. S. Chou }\end{array}$ \\
\hline 66 & $\begin{array}{l}\text { Interstate } 90 \text { and } \\
\text { Rainier Ave } \\
\text { Interchange, Seattle }\end{array}$ & \begin{tabular}{|l} 
Mechanically \\
Stabilized \\
Earth
\end{tabular} & $\begin{array}{l}\text { No } \\
\text { Additional } \\
\text { Support }\end{array}$ & 12.6 & $\begin{array}{l}\text { T. M. Allen; B. R. } \\
\text { Christopher; R. D: } \\
\text { Holtz }\end{array}$ \\
\hline 67 & $\begin{array}{l}\text { Cathedral Square } \\
\text { Substation, } \\
\text { Vancouver }\end{array}$ & Soldier Piles & Tieback & 20.0 & $\begin{array}{l}\text { Vinod K. Garcia; } \\
\text { Edward I. Carey; } \\
\text { Robert W. Milne }\end{array}$ \\
\hline 68 & $\begin{array}{l}\text { Ramp L Fort Point } \\
\text { Channel Crossing, } \\
\text { Boston }\end{array}$ & Soil-Cement & $\begin{array}{l}\text { Soil } \\
\text { Improvement } \\
\text { and Braced }\end{array}$ & 17.0 & $\begin{array}{l}\text { James R. } \\
\text { Lambrechts; Paul } \\
\text { A. Roy \& Eric J. } \\
\text { Wishart } \\
\end{array}$ \\
\hline 69 & $\begin{array}{l}\text { Kam-River, Thunder } \\
\text { bay }\end{array}$ & \begin{tabular}{|l} 
Soldier Piles \\
\end{tabular} & Tieback & 11.5 & $\begin{array}{l}\text { K. D. Eigenbrod; J. } \\
\text { P. Burak }\end{array}$ \\
\hline 70 & $\begin{array}{l}\text { Lake Tamblyn, } \\
\text { Lakehead University } \\
\text { Campus, Thunder } \\
\text { Bay }\end{array}$ & Sheet Piles & Tieback & 5.8 & $\begin{array}{l}\text { K. D. Eigenbrod; J. } \\
\text { P. Burak }\end{array}$ \\
\hline 71 & $\begin{array}{l}\text { Wing-wall at Lake } \\
\text { Tamblyn Fish } \\
\text { Ladder, Lakehead } \\
\text { University Campus, } \\
\text { Thunder Bay }\end{array}$ & Sheet Piles & Tieback & 2.1 & $\begin{array}{l}\text { K. D. Eigenbrod; J. } \\
\text { P. Burak }\end{array}$ \\
\hline 72 & $\begin{array}{l}\text { Commercial } \\
\text { Development } \\
\text { support system }\end{array}$ & Soil Nailing & $\begin{array}{l}\text { No } \\
\text { Additional } \\
\text { Support }\end{array}$ & 16.5 & $\begin{array}{l}\text { Suan S. Cheng and } \\
\text { Lawrence A. } \\
\text { Hansen }\end{array}$ \\
\hline 73 & $\begin{array}{l}\text { St. Louis Center } \\
\text { Metro Link Light } \\
\text { Rail Station, St } \\
\text { Louis } \\
\end{array}$ & Soldier Piles & Tieback & 9.2 & $\begin{array}{l}\text { John Reinfurt; } \\
\text { Thomas C. } \\
\text { Anderson; Paul } \\
\text { Reitz; Tony Licari } \\
\end{array}$ \\
\hline 74 & $\begin{array}{l}\text { Eight and Pine } \\
\text { Metro Link Light } \\
\text { Rail Station, St } \\
\text { Louis }\end{array}$ & \begin{tabular}{|l|} 
Soldier Piles \\
\end{tabular} & Tieback & 9.2 & $\begin{array}{l}\text { John Reinfurt; } \\
\text { Thomas C. } \\
\text { Anderson; Paul } \\
\text { Reitz; Tony Licari }\end{array}$ \\
\hline
\end{tabular}


Table 3.2 Listing of Case History Review: Literature (Cont'd)

\begin{tabular}{|c|c|c|c|c|c|}
\hline ID & Name & Type & Support & $\mathbf{H}(\mathbf{m})$ & Reference \\
\hline 75 & $\begin{array}{l}\text { Ventilation Building } \\
\text { on the Central } \\
\text { Artery Tunnel } \\
\text { Project, Boston }\end{array}$ & Cast in-situ & Other & 30.0 & $\begin{array}{l}\text { J. Taylor; W. } \\
\text { Galbraith; G. } \\
\text { Richters; J. Baka; } \\
\text { C. Chang }\end{array}$ \\
\hline 76 & $\begin{array}{l}\text { Liberty Street } \\
\text { Bridge, Clinton }\end{array}$ & Soldier Piles & Tieback & 12.0 & David R. Chapman \\
\hline 77 & $\begin{array}{l}\text { Timber Wall Failure } \\
\text { Remediation, } \\
\text { Piedmont }\end{array}$ & Soldier Piles & Soil Nailing & & $\begin{array}{l}\text { James Harmston; } \\
\text { Garry W. Rhodes }\end{array}$ \\
\hline 78 & $\begin{array}{l}\text { Timber Wall Failure, } \\
\text { Piedmont }\end{array}$ & Soldier Piles & Tieback & & $\begin{array}{l}\text { James Harmston; } \\
\text { Garry W. Rhodes }\end{array}$ \\
\hline 79 & $\begin{array}{l}\text { Water Street's Steel } \\
\text { Bin Retaining Wall } \\
\text { Failure, Racine }\end{array}$ & Crib/Bin & $\begin{array}{l}\text { No } \\
\text { Additional } \\
\text { Support }\end{array}$ & 8.1 & $\begin{array}{l}\text { Steven W. Hunt; } \\
\text { Randy Frank; Paul } \\
\text { Tarvin; James } \\
\text { Blazek }\end{array}$ \\
\hline 80 & $\begin{array}{l}\text { Water Street's Steel } \\
\text { Bin Retaining Wall } \\
\text { Remediation, Racine }\end{array}$ & Sheet Piles & Tieback & 10.0 & $\begin{array}{l}\text { Steven W. Hunt; } \\
\text { Randy Frank; Paul } \\
\text { Tarvin; James } \\
\text { Blazek }\end{array}$ \\
\hline 81 & $\begin{array}{l}\text { Ramp D tunnel } \\
\text { jacking pit, Boston }\end{array}$ & Piles & $\begin{array}{l}\text { Soil } \\
\text { Improvement } \\
\text { and Braced }\end{array}$ & 19.5 & $\begin{array}{l}\text { Phillip Ooi; } \\
\text { Michael Walker; } \\
\text { Hans van den } \\
\text { Elsen; Phillip Rice }\end{array}$ \\
\hline 82 & $\begin{array}{l}\text { Wando Terminal, } \\
\text { Charleston }\end{array}$ & $\begin{array}{l}\text { Mechanically } \\
\text { Stabilized } \\
\text { Earth }\end{array}$ & $\begin{array}{l}\text { No } \\
\text { Additional } \\
\text { Support }\end{array}$ & 4.7 & Alan T. Stadler \\
\hline 83 & $\begin{array}{l}\text { Nova Dutra Project, } \\
\text { Sao Paulo }\end{array}$ & $\begin{array}{l}\text { Tailed } \\
\text { Masonry }\end{array}$ & $\begin{array}{l}\text { Soil } \\
\text { Improvement }\end{array}$ & 8.2 & $\begin{array}{l}\text { Daniel Alzamora; } \\
\text { Mark H. Wayne; } \\
\text { Jie Han }\end{array}$ \\
\hline 84 & $\begin{array}{l}\text { M25 cut and Cover } \\
\text { tunnel, Bell } \\
\text { Common, London }\end{array}$ & Cast in-situ & Braced & 9.3 & $\begin{array}{l}\text { H. W. Hubbard; D. } \\
\text { M. Potts; D. } \\
\text { Miller; J. B. } \\
\text { Burland }\end{array}$ \\
\hline 85 & $\begin{array}{l}\text { M26 Sevenoaks } \\
\text { Interchange, Dunton } \\
\text { Green, London }\end{array}$ & Cast in-situ & $\begin{array}{l}\text { No } \\
\text { Additional } \\
\text { Support }\end{array}$ & 7.2 & $\begin{array}{l}\text { C. Garrett; S. J. } \\
\text { Barnes }\end{array}$ \\
\hline 86 & $\begin{array}{l}\text { Deep Basement, } \\
\text { Westminster }\end{array}$ & Cast in-situ & Braced & 11.0 & $\begin{array}{l}\text { L. A. Wood and A. } \\
\text { J. Perrin }\end{array}$ \\
\hline
\end{tabular}


Table 3.2 Listing of Case History Review: Literature (Cont'd)

\begin{tabular}{|c|c|c|c|c|c|}
\hline ID & Name & Type & Support & H (m) & Reference \\
\hline 87 & $\begin{array}{l}\text { Deep Excavation, } \\
\text { Struttgart }\end{array}$ & Soil Nailing & $\begin{array}{l}\text { No } \\
\text { Additional } \\
\text { Support }\end{array}$ & 14.5 & $\begin{array}{l}\text { Manfred F. } \\
\text { Stocker; Georg } \\
\text { Riedinger }\end{array}$ \\
\hline 88 & $\begin{array}{l}\text { Soil nail wall } \\
\text { (lower), Seattle }\end{array}$ & Soil Nailing & $\begin{array}{l}\text { No } \\
\text { Additional } \\
\text { Support }\end{array}$ & 10.7 & $\begin{array}{l}\text { Steven Thompson, } \\
\text { A. M. ASCE; Ian } \\
\text { Miller }\end{array}$ \\
\hline 89 & $\begin{array}{l}\text { Soil nail wall } \\
\text { (higher), Seattle }\end{array}$ & Soil Nailing & $\begin{array}{l}\text { No } \\
\text { Additional } \\
\text { Support }\end{array}$ & 16.8 & $\begin{array}{l}\text { Steven Thompson, } \\
\text { A. M. ASCE; Ian } \\
\text { Miller }\end{array}$ \\
\hline 90 & $\begin{array}{l}\text { Clouterre, Saint- } \\
\text { Remy Les } \\
\text { Chevreuse }\end{array}$ & Soil Nailing & $\begin{array}{l}\text { No } \\
\text { Additional } \\
\text { Support }\end{array}$ & 7.0 & $\begin{array}{l}\text { C. Plumelle; F. } \\
\text { Shlosser; P. } \\
\text { Delage; G. } \\
\text { Knochenmus }\end{array}$ \\
\hline
\end{tabular}

\subsubsection{Case History Review: INDOT's Database}

Information on retaining devices used in the State of Indiana is necessary to assess the local practice and experience. INDOT's Contracts and Construction Division in Indianapolis maintains an extensive database of their projects. Within that database information is kept regarding item bid costs and contract number identification of every project. For this project, Mr. Gregory Pankow of the Contracts and Construction Division of INDOT facilitated access to this database. Through his assistance seventy-six (76) cases of retaining devices from projects being let in the past five years have been identified and incorporated into this project's database. All items in the original raw data are transformed into the metric system and placed in a table in our research database. This table is named Case History Review: INDOT Database (CHRID). 
Table 3.3 shows the fields of the table, their data type, their lookups, and their documented description. The field CONTID stores INDOT's contract id number for the project; COUNTY stores the county where the project is located; LETTING has the letting date of the project; LINE has one of the lines of the project budget with a retaining structure item; ITEM has the item number from the LINE field; DESC has the description of the item; Quantity_ has the quantity of the item; UNIT_ has the units of the Quantity_ field; and, Price_ has the unit price of the item.

Table 3.3 Field Description of Case History Review: INDOT Database

\begin{tabular}{|l|l|l|l|}
\hline Field & Data Type & Lookup & Description \\
\hline CONTID & Text & & INDOT Contract Id Number \\
\hline COUNTY & Text & & Project Location (County of Indiana) \\
\hline LETTING & Date/Time & & Letting Date of the contract \\
\hline LINE & Text & & Budget Line \\
\hline ITEM & Text & & Budget Item \\
\hline DESC & Text & & Item Description \\
\hline Quantity_ & Number & & Item Quantity \\
\hline UNIT__ & Text & & Quantity Units \\
\hline Price__ & Number & & Unit Price \\
\hline
\end{tabular}

A listing of the CHRID table is shown in Table 3.4. This table gives the unit price costs bid for INDOT projects for the past five years. It also gives an insight into the retaining device practice for INDOT projects. This listing is created with the select query named: “:Query CHR INDOT Listing”. The columns of the table: Contract No., Indiana County and Letting Date correspond to the fields CONTID, COUNTY and LETTING, as described previously. The "Id" column enumerates the cases; the "Type" column shows the selected retaining device type corresponding to the "ITEM" field information; the "Total Cost" column shows the total cost of the wall calculated with the item quantities 
and unit prices for each type of wall. It can be observed that these last three columns are not part of the fields stored by the table CHRID. However, relations to obtain the "Type" by item, and calculations for the "Total Cost" by wall are performed in the select query: “:Query CHR INDOT Listing” of our database. The report "Report Table: Listing of Case History Review: Literature" was used to create the following table. The N/A on the "Type" column reflects items that were only identified in the original data as walls or retaining walls.

Table 3.4 Listing of Case History Review: INDOT Database

\begin{tabular}{|c|c|c|c|c|c|}
\hline ID & $\begin{array}{l}\text { Contract } \\
\text { No. }\end{array}$ & Indiana County & $\begin{array}{l}\text { Letting } \\
\text { Date }\end{array}$ & $\begin{array}{l}\text { Type } \\
\text { (Research) }\end{array}$ & Total Cost \\
\hline 1 & $\mathrm{R}-22346$ & GIBSON & 20-Feb-96 & $\begin{array}{l}\text { Mechanically } \\
\text { Stabilized } \\
\text { Earth Walls }\end{array}$ & 14216.35 \\
\hline 2 & $\mathrm{R}-22343$ & DEKALB & 14-May-96 & $\begin{array}{l}\text { Mechanically } \\
\text { Stabilized } \\
\text { Earth Walls }\end{array}$ & 138556.80 \\
\hline 3 & B -22236 & MARION & 16-Jul-96 & $\begin{array}{l}\text { Mechanically } \\
\text { Stabilized } \\
\text { Earth Walls }\end{array}$ & 161772.80 \\
\hline 4 & B -22609 & JEFFERSON & 13-Aug-96 & $\begin{array}{l}\text { Mechanically } \\
\text { Stabilized } \\
\text { Earth Walls }\end{array}$ & 144198.00 \\
\hline 5 & R -22687 & TIPPECANOE & 17-Sep-96 & $\begin{array}{l}\text { Flexible } \\
\text { Gravity Walls }\end{array}$ & 71530.00 \\
\hline 6 & R -22688 & MARION & 17-Sep-96 & $\begin{array}{l}\text { Mechanically } \\
\text { Stabilized } \\
\text { Earth Walls }\end{array}$ & 41154.17 \\
\hline 7 & $R-22689$ & BOONE & 23-Oct-96 & $\begin{array}{l}\text { Flexible } \\
\text { Gravity Walls }\end{array}$ & 43924.30 \\
\hline 8 & B -22322 & JEFFERSON & 23-Oct-96 & $\begin{array}{l}\text { Mechanically } \\
\text { Stabilized } \\
\text { Earth Walls }\end{array}$ & 18500.00 \\
\hline 9 & B -22364 & LAKE & 19-Nov-96 & $\begin{array}{l}\text { Mechanically } \\
\text { Stabilized } \\
\text { Earth Walls }\end{array}$ & 1980.00 \\
\hline
\end{tabular}


Table 3.4 Listing of Case History Review: INDOT Database (Cont'd)

\begin{tabular}{|c|c|c|c|c|c|}
\hline ID & $\begin{array}{l}\text { Contract } \\
\text { No. }\end{array}$ & Indiana County & $\begin{array}{l}\text { Letting } \\
\text { Date }\end{array}$ & $\begin{array}{l}\text { Type } \\
\text { (Research) }\end{array}$ & Total Cost \\
\hline 10 & R -21860 & LAKE & 19-Nov-96 & $\begin{array}{l}\text { Mechanically } \\
\text { Stabilized } \\
\text { Earth Walls }\end{array}$ & 1980.00 \\
\hline 11 & $\mathrm{R}-22858$ & JENNINGS & 17-Dec-96 & N/A & 7040.00 \\
\hline 12 & R -22681 & VANDERBURGH & 14-Jan-97 & $\begin{array}{l}\text { Mechanically } \\
\text { Stabilized } \\
\text { Earth Walls }\end{array}$ & 12400.00 \\
\hline 13 & R -22521 & MONROE & 14-Jan-97 & $\begin{array}{l}\text { Mechanically } \\
\text { Stabilized } \\
\text { Earth Walls }\end{array}$ & 20325.00 \\
\hline 14 & R -22917 & GIBSON & 14-Jan-97 & N/A & 816044.90 \\
\hline 15 & R -21103 & PUTNAM & 11-Feb-97 & $\begin{array}{l}\text { Mechanically } \\
\text { Stabilized } \\
\text { Earth Walls }\end{array}$ & 7801.20 \\
\hline 16 & R -22918 & MARION & 11-Feb-97 & $\begin{array}{l}\text { Mechanically } \\
\text { Stabilized } \\
\text { Earth Walls }\end{array}$ & 97622.00 \\
\hline 17 & R -22774 & LAKE & 11-Mar-97 & $\begin{array}{l}\text { Rigid and } \\
\text { Cantilever } \\
\text { Gravity Walls }\end{array}$ & 34000.00 \\
\hline 18 & B -23070 & VANDERBURGH & 11-Mar-97 & $\begin{array}{l}\text { Mechanically } \\
\text { Stabilized } \\
\text { Earth Walls }\end{array}$ & 973830.00 \\
\hline 19 & R -23007 & LAKE & 11-Mar-97 & $\begin{array}{l}\text { Mechanically } \\
\text { Stabilized } \\
\text { Earth Walls }\end{array}$ & 1139856.60 \\
\hline 20 & R - 22771 & LAWRENCE & 08-Apr-97 & N/A & 4294.08 \\
\hline 21 & R -23127 & LAKE & 13-Мay-97 & N/A & 9222.48 \\
\hline 22 & R -23202 & LAKE & 20-Nov-97 & $\begin{array}{l}\text { Mechanically } \\
\text { Stabilized } \\
\text { Earth Walls }\end{array}$ & 123924.00 \\
\hline 23 & $\mathrm{R}-22228$ & BARTHOLOMEW & 20-Nov-97 & N/A & 29455.00 \\
\hline 24 & B -23404 & GRANT & 16-Dec-97 & $\begin{array}{l}\text { Mechanically } \\
\text { Stabilized } \\
\text { Earth Walls }\end{array}$ & 164965.55 \\
\hline 25 & R -23364 & CASS & 16-Dec-97 & $\begin{array}{l}\text { Mechanically } \\
\text { Stabilized } \\
\text { Earth Walls }\end{array}$ & 1518490.14 \\
\hline
\end{tabular}


Table 3.4 Listing of Case History Review: INDOT Database (Cont'd)

\begin{tabular}{|c|c|c|c|c|c|}
\hline ID & $\begin{array}{l}\text { Contract } \\
\text { No. }\end{array}$ & Indiana County & $\begin{array}{l}\text { Letting } \\
\text { Date }\end{array}$ & $\begin{array}{l}\text { Type } \\
\text { (Research) }\end{array}$ & Total Cost \\
\hline 26 & B - 23520 & LAKE & 10-Feb-98 & $\begin{array}{l}\text { Mechanically } \\
\text { Stabilized } \\
\text { Earth Walls }\end{array}$ & 1919.52 \\
\hline 27 & R -23729 & FLOYD & 12-May-98 & N/A & 40000.00 \\
\hline 28 & B -23885 & LAWRENCE & 29-Мay-98 & $\begin{array}{l}\text { Mechanically } \\
\text { Stabilized } \\
\text { Earth Walls }\end{array}$ & 17217.28 \\
\hline 29 & R -23796 & WAYNE & 11-Jun-98 & N/A & 455532.00 \\
\hline 30 & $\mathrm{R}-23627$ & FRANKLIN & 14-Jul-98 & $\begin{array}{l}\text { Rigid and } \\
\text { Cantilever } \\
\text { Gravity Walls }\end{array}$ & 23500.00 \\
\hline 31 & R -23393 & FLOYD & 14-Jul-98 & $\begin{array}{l}\text { Mechanically } \\
\text { Stabilized } \\
\text { Earth Walls }\end{array}$ & 25169.40 \\
\hline 32 & R -23730 & ELKHART & 14-Jul-98 & $\begin{array}{l}\text { Mechanically } \\
\text { Stabilized } \\
\text { Earth Walls }\end{array}$ & 8500.00 \\
\hline 33 & B -23864 & WAYNE & 10-Sep-98 & $\begin{array}{l}\text { Mechanically } \\
\text { Stabilized } \\
\text { Earth Walls }\end{array}$ & 6482.10 \\
\hline 34 & B -23864 & WAYNE & 10-Sep-98 & $\begin{array}{l}\text { Mechanically } \\
\text { Stabilized } \\
\text { Earth Walls }\end{array}$ & 134859.00 \\
\hline 35 & B - 23883 & DEKALB & 10-Sep-98 & N/A & 912800.54 \\
\hline 36 & R -23808 & LAKE & 17-Sep-98 & $\begin{array}{l}\text { Mechanically } \\
\text { Stabilized } \\
\text { Earth Walls }\end{array}$ & 285802.35 \\
\hline 37 & R -23631 & BARTHOLOMEW & 20-Jan-99 & $\begin{array}{l}\text { Additional } \\
\text { Support }\end{array}$ & 251300.00 \\
\hline 38 & R -24148 & TIPPECANOE & 20-Jan-99 & $\begin{array}{l}\text { Mechanically } \\
\text { Stabilized } \\
\text { Earth Walls }\end{array}$ & 269235.40 \\
\hline 39 & B -23659 & MARION & 23-Feb-99 & $\begin{array}{l}\text { Mechanically } \\
\text { Stabilized } \\
\text { Earth Walls }\end{array}$ & 203180.00 \\
\hline 40 & B -23737 & PORTER & 23-Feb-99 & $\begin{array}{l}\text { Mechanically } \\
\text { Stabilized } \\
\text { Earth Walls }\end{array}$ & 109590.00 \\
\hline
\end{tabular}


Table 3.4 Listing of Case History Review: INDOT Database (Cont'd)

\begin{tabular}{|c|c|c|c|c|c|}
\hline ID & $\begin{array}{l}\text { Contract } \\
\text { No. }\end{array}$ & Indiana County & $\begin{array}{l}\text { Letting } \\
\text { Date }\end{array}$ & $\begin{array}{l}\text { Type } \\
\text { (Research) }\end{array}$ & Total Cost \\
\hline 41 & R - 23640 & LAKE & 23-Mar-99 & $\begin{array}{l}\text { Additional } \\
\text { Support }\end{array}$ & 325000.00 \\
\hline 42 & B -24293 & VANDERBURGH & 23-Mar-99 & $\begin{array}{l}\text { Flexible } \\
\text { Gravity Walls }\end{array}$ & 147614.26 \\
\hline 43 & B -23291 & PORTER & 23-Mar-99 & $\begin{array}{l}\text { Mechanically } \\
\text { Stabilized } \\
\text { Earth Walls }\end{array}$ & 131878.65 \\
\hline 44 & B -24029 & CLARK & 23-Mar-99 & $\begin{array}{l}\text { Mechanically } \\
\text { Stabilized } \\
\text { Earth Walls }\end{array}$ & 202782.50 \\
\hline 45 & R -23398 & CLARK & 23-Mar-99 & $\begin{array}{l}\text { Mechanically } \\
\text { Stabilized } \\
\text { Earth Walls }\end{array}$ & 371360.00 \\
\hline 46 & R - 23640 & LAKE & 23-Mar-99 & $\begin{array}{l}\text { Mechanically } \\
\text { Stabilized } \\
\text { Earth Walls }\end{array}$ & 146957.00 \\
\hline 47 & B -23877 & SCOTT & 20-Apr-99 & $\begin{array}{l}\text { Mechanically } \\
\text { Stabilized } \\
\text { Earth Walls }\end{array}$ & 4617.00 \\
\hline 48 & R -24287 & ORANGE & 18-May-99 & $\begin{array}{l}\text { Mechanically } \\
\text { Stabilized } \\
\text { Earth Walls }\end{array}$ & 23499.00 \\
\hline 49 & R -24321 & MARION & 18-Мау-99 & N/A & 994487.27 \\
\hline 50 & R -24419 & ST. JOSEPH & 20-Jul-99 & N/A & 15545.48 \\
\hline 51 & R -23924 & MONROE & 17-Aug-99 & $\begin{array}{l}\text { Mechanically } \\
\text { Stabilized } \\
\text { Earth Walls }\end{array}$ & 749920.81 \\
\hline 52 & B -23744 & LAWRENCE & 13-Oct-99 & $\begin{array}{l}\text { Mechanically } \\
\text { Stabilized } \\
\text { Earth Walls }\end{array}$ & 28468.06 \\
\hline 53 & R -24434 & FLOYD & 13-Oct-99 & $\begin{array}{l}\text { Mechanically } \\
\text { Stabilized } \\
\text { Earth Walls }\end{array}$ & 58147.35 \\
\hline 54 & R -23797 & HENDRICKS & 16-Nov-99 & $\begin{array}{l}\text { Mechanically } \\
\text { Stabilized } \\
\text { Earth Walls }\end{array}$ & 4180.20 \\
\hline 55 & R - 24437 & JOHNSON & 16-Nov-99 & N/A & 26275.00 \\
\hline
\end{tabular}


Table 3.4 Listing of Case History Review: INDOT Database (Cont'd)

\begin{tabular}{|c|c|c|c|c|c|}
\hline ID & $\begin{array}{l}\text { Contract } \\
\text { No. }\end{array}$ & Indiana County & $\begin{array}{l}\text { Letting } \\
\text { Date }\end{array}$ & $\begin{array}{l}\text { Type } \\
\text { (Research) }\end{array}$ & Total Cost \\
\hline 56 & -- & WAYNE & 14-Dec-99 & $\begin{array}{l}\text { Mechanically } \\
\text { Stabilized } \\
\text { Earth Walls }\end{array}$ & 1700.00 \\
\hline 57 & R -24424 & WAYNE & 14-Dec-99 & $\begin{array}{l}\text { Mechanically } \\
\text { Stabilized } \\
\text { Earth Walls }\end{array}$ & 5174.00 \\
\hline 58 & R - 24428 & MARTIN & 14-Dec-99 & $\begin{array}{l}\text { Mechanically } \\
\text { Stabilized } \\
\text { Earth Walls }\end{array}$ & 17116.12 \\
\hline 59 & R -24429 & LAKE & 14-Dec-99 & $\begin{array}{l}\text { Mechanically } \\
\text { Stabilized } \\
\text { Earth Walls }\end{array}$ & 244894.50 \\
\hline 60 & $\mathrm{R}-23465$ & HENDRICKS & 19-Jan-00 & $\begin{array}{l}\text { Mechanically } \\
\text { Stabilized } \\
\text { Earth Walls }\end{array}$ & 33324.24 \\
\hline 61 & R -24725 & MARION & 19-Jan-00 & $\begin{array}{l}\text { Mechanically } \\
\text { Stabilized } \\
\text { Earth Walls }\end{array}$ & 1434549.83 \\
\hline 62 & R -24288 & WAYNE & 22-Feb-00 & $\begin{array}{l}\text { Mechanically } \\
\text { Stabilized } \\
\text { Earth Walls }\end{array}$ & 1420.00 \\
\hline 63 & R -24549 & LAWRENCE & 22-Feb-00 & $\begin{array}{l}\text { Mechanically } \\
\text { Stabilized } \\
\text { Earth Walls }\end{array}$ & 3105.90 \\
\hline 64 & R -24432 & MARION & 22-Feb-00 & $\begin{array}{l}\text { Soil Nailed } \\
\text { Walls }\end{array}$ & 1231245.97 \\
\hline 65 & R -24549 & LAWRENCE & 22-Feb-00 & N/A & 20010.00 \\
\hline 66 & R -24432 & MARION & 22-Feb-00 & N/A & 206490.86 \\
\hline 67 & R -24548 & MONROE & 21-Mar-00 & $\begin{array}{l}\text { Mechanically } \\
\text { Stabilized } \\
\text { Earth Walls }\end{array}$ & 1475365.10 \\
\hline 68 & R -24075 & VIGO & 11-Apr-00 & $\begin{array}{l}\text { Soil Nailed } \\
\text { Walls }\end{array}$ & 206674.68 \\
\hline 69 & R -24952 & JEFFERSON & 18-Apr-00 & $\begin{array}{l}\text { Rigid and } \\
\text { Cantilever } \\
\text { Gravity Walls }\end{array}$ & 13832.00 \\
\hline 70 & R -24552 & CLARK & 18-Apr-00 & $\begin{array}{l}\text { Mechanically } \\
\text { Stabilized } \\
\text { Earth Walls } \\
\end{array}$ & 2010630.50 \\
\hline
\end{tabular}


Table 3.4 Listing of Case History Review: INDOT Database (Cont'd)

\begin{tabular}{|l|l|l|l|l|r|}
\hline ID & $\begin{array}{l}\text { Contract } \\
\text { No. }\end{array}$ & Indiana County & $\begin{array}{l}\text { Letting } \\
\text { Date }\end{array}$ & $\begin{array}{l}\text { Type } \\
\text { (Research) }\end{array}$ & Total Cost \\
\hline 71 & R -24846 & JACKSON & 23-May-00 & $\begin{array}{l}\text { Mechanically } \\
\text { Stabilized } \\
\text { Earth Walls }\end{array}$ & 7215.00 \\
\hline 72 & R -24861 & ALLEN & 23-May-00 & $\begin{array}{l}\text { Mechanically } \\
\text { Stabilized } \\
\text { Earth Walls }\end{array}$ & 886426.50 \\
\hline 73 & T -24619 & FLOYD & 23-May-00 & $\begin{array}{l}\text { Mechanically } \\
\text { Stabilized } \\
\text { Earth Walls }\end{array}$ & 16520.00 \\
\hline 74 & R -25034 & MARION & 18-Jul-00 & $\begin{array}{l}\text { Mechanically } \\
\text { Stabilized } \\
\text { Earth Walls }\end{array}$ & 28241.97 \\
\hline 75 & R -25028 & MADISON & 17-Oct-00 & $\begin{array}{l}\text { Mechanically } \\
\text { Stabilized } \\
\text { Earth Walls }\end{array}$ & 49400.00 \\
\hline 76 & R -25128 & LAKE & 20-Dec-00 & $\begin{array}{l}\text { Mechanically } \\
\text { Stabilized } \\
\text { Earth Walls }\end{array}$ & 170132.00 \\
\hline
\end{tabular}

The information in the table CHRID contains only wall type and cost. Cases with factors like dimensions and soil type are necessary to fully grasp INDOT's retaining device practice. From Table 3.4, a total of six (6) representative cases are further investigated and information has been gathered from a number of visits to INDOT's archives. The six cases are chosen to obtain: a representative case of each group classified in Chapter 2; when more than one case exists for each group the device with the largest height is chosen. A total of three (3) visits to the INDOT Contracts and Construction Division offices were needed to gather this information. Shop plans, boring logs, and correspondence for each of these projects has been examined comprehensively. The information gathered from this effort is stored in the table Case History Review: Indiana 
(see Section 3.4.3). The six projects selected from INDOT's database produce twenty cases, since some of the projects have more than one retaining device. These cases are reported in the Case History Review: Indiana table (see next section), because the field format created for the Indiana cases fit the INDOT data.

\subsubsection{Case History Review: Indiana}

A total of 41 cases are stored in this table. This table stores information of case histories of retaining devices located in the State of Indiana. These records reflect the practice and trends of the local industry.

Two sources were used to obtain the data for this table. The first one, as mentioned in the previous section, is the INDOT database. The archives of INDOT were examined and the available information needed is stored in the database.

The second source is from designers and contractors working in the state of Indiana. A survey form was prepared for this purpose and sent by email and fax to a total of twenty (20) companies. The survey sheet is included in Figure 3.4.The survey was sent to the companies from May to July 2001. Collection of replies concluded in August 2001. The survey form requests the field information required for the table. The response from this survey was positive with a feedback rate of around $30 \%$.

The Case History Review: Indiana (CHRI) table is similar to the CHRL table since both store analogous data with slight variations in the fields they collect. Table 3.5 shows the fields of the table, their data type, their lookups, and their documented description. 


\section{PURDUE UNIVERSITY}

Survey of Retaining Devices in Indiana

Guidelines for use of types of retaining devices research

A. Name of Project:

B. Location:

C. Type of Retaining Structure: (choose one)

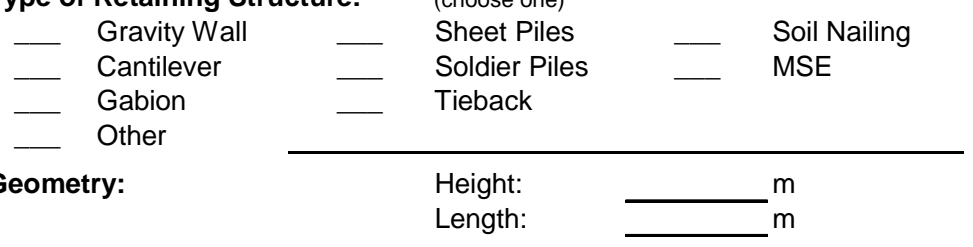

E. Subsurface Condition:

E.1 Foundation Soil: Description Strength Properties:

E.2 Backfill Soil: Description Strength Properties:

F. Design Remarks: (Special complications of the project)

G. Construction Remarks: (Costs, Difficulties during construction, etc.)

H. Monitoring \& Performance Observations: (Costs, records, etc)

I. Other Remarks:

Figure 3.4 Survey Form

The available information of the 41 cases is used to fill all the important factors, as described in Section 3.3. The field IDIN_Case is the primary key of the table and stores 
the case id number; Source, Reference, Contact, Source2, Reference2, and Contact2 have the reference information for the project. The fields: Name, Loc, Type, Support, Height, Length, BF/SS, Found, Status, Descrip, SubCon, Sdesc, ExpPer, and Reminder are described in Section 3.4.1.

Table 3.5 Field Description of Case History Review: Indiana

\begin{tabular}{|l|l|l|l|}
\hline Field & Data Type & Lookup & Description \\
\hline IDIN_Case & AutoNumber & & Primary Key \\
\hline Name & Text & & Case Name \\
\hline Loc & Number & Types: Locations & Location (State/Province/Country) \\
\hline Type & Number & $\begin{array}{l}\text { Types: Retaining } \\
\text { Structure }\end{array}$ & Retaining Wall Type \\
\hline Support & Number & $\begin{array}{l}\text { Types: Additional } \\
\text { Support }\end{array}$ & Additional Support \\
\hline Height & Number & & Height of wall \\
\hline Length & Number & & Length of wall \\
\hline BF/SS & Number & Types: Soil & Backfill/Site Subsoil \\
\hline Found & Number & Types: Soil & Foundation Subsoil \\
\hline Status & Number & $\begin{array}{l}\text { Types: Walls' } \\
\text { Status }\end{array}$ & Status of the wall (Serviceability) \\
\hline Source & Text & & Source 1 \\
\hline Reference & Text & & Contributor 1 Reference \\
\hline Contact & Number & Contacts: General & Contributor 1 Contact \\
\hline Source2 & Text & & Source 2 \\
\hline Reference2 & Text & & Contributor 2 Reference \\
\hline Contact2 & Number & Contacts: General & Contributor 2 Contact \\
\hline Descrip & Memo & & Project Description \\
\hline SubCon & Memo & & Subsurface Conditions \\
\hline Sdesc & Number & $\begin{array}{l}\text { Types: Soil - } \\
\text { Description }\end{array}$ & Origin of Subsoil Observations \\
\hline ExpPer & Memo & & Experience \& Performance \\
\hline Reminder & Memo & & Key points of case \\
\hline
\end{tabular}

The cases stored in table CHRI are listed in Table 3.6. The cases are accompanied by some of the fields of the database as described previously. The columns shown correspond to the following fields: IDIN_Case, Name, Type, Support, Height (if 
available), Contact and Source. This listing is created with the report: "Report Table: Listing of Case History Review: Indiana”.

Table 3.6 Listing of Case History Review: Indiana

\begin{tabular}{|c|c|c|c|c|c|c|}
\hline ID & Name & Type & Support & H (m) & $\begin{array}{l}\text { Contact } \\
\text { Name }\end{array}$ & Company \\
\hline 1 & $\begin{array}{l}\text { Lafayette RR } \\
\text { Reloc. - } \\
\text { Access Rd } \\
\text { from CSX RR } \\
\text { Yard, } \\
\text { Lafayette }\end{array}$ & Crib/Bin & $\begin{array}{l}\text { No } \\
\text { Additional } \\
\text { Support }\end{array}$ & 3.4 & $\begin{array}{l}\text { Elizabeth } \\
\text { M. } \\
\text { Dwyre }\end{array}$ & $\begin{array}{l}\text { Professional } \\
\text { Service } \\
\text { Industries, } \\
\text { Inc. }\end{array}$ \\
\hline 2 & $\begin{array}{l}\text { US } 231 \\
\text { Relocation at } \\
\text { Wiggins St., } \\
\text { West } \\
\text { Lafayette }\end{array}$ & Soldier Piles & Tieback & 8.0 & $\begin{array}{l}\text { Elizabeth } \\
\text { M. } \\
\text { Dwyre }\end{array}$ & $\begin{array}{l}\text { Professional } \\
\text { Service } \\
\text { Industries, } \\
\text { Inc. }\end{array}$ \\
\hline 3 & $\begin{array}{l}\text { CSX Over } \\
\text { Randolph St, } \\
\text { Garret }\end{array}$ & Soldier Piles & Tieback & 5.3 & $\begin{array}{l}\text { Elizabeth } \\
\text { M. } \\
\text { Dwyre }\end{array}$ & $\begin{array}{l}\text { Professional } \\
\text { Service } \\
\text { Industries, } \\
\text { Inc. }\end{array}$ \\
\hline 4 & $\begin{array}{l}\text { Laf. RR Reloc } \\
\text {-Smith St } \\
\text { Pedestrian } \\
\text { Bridge, } \\
\text { Lafayette }\end{array}$ & $\begin{array}{l}\text { Mechanically } \\
\text { Stabilized } \\
\text { Earth }\end{array}$ & $\begin{array}{l}\text { No } \\
\text { Additional } \\
\text { Support }\end{array}$ & 7.5 & $\begin{array}{l}\text { Elizabeth } \\
\text { M. } \\
\text { Dwyre }\end{array}$ & $\begin{array}{l}\text { Professional } \\
\text { Service } \\
\text { Industries, } \\
\text { Inc. }\end{array}$ \\
\hline 5 & $\begin{array}{l}\text { Laf. RR } \\
\text { Reloc. - Rush } \\
\text { Metal } \\
\text { Products Wall, } \\
\text { Lafayette }\end{array}$ & Sheet Piles & $\begin{array}{l}\text { No } \\
\text { Additional } \\
\text { Support }\end{array}$ & 2.0 & $\begin{array}{l}\text { Elizabeth } \\
\text { M. } \\
\text { Dwyre }\end{array}$ & $\begin{array}{l}\text { Professional } \\
\text { Service } \\
\text { Industries, } \\
\text { Inc. }\end{array}$ \\
\hline 6 & $\begin{array}{l}\text { SR 56, } \\
\text { Jefferson } \\
\text { County }\end{array}$ & Cast in-situ & Tieback & 8.0 & $\begin{array}{l}\text { Matthew } \\
\text { J. Crane }\end{array}$ & $\begin{array}{l}\text { Paul I. Cripe, } \\
\text { Inc. }\end{array}$ \\
\hline 7 & $\begin{array}{l}\text { Calumet } \\
\text { Avenue } \\
\text { Interchange } \\
\text { Modification }\end{array}$ & $\begin{array}{l}\text { Mechanically } \\
\text { Stabilized } \\
\text { Earth }\end{array}$ & $\begin{array}{l}\text { No } \\
\text { Additional } \\
\text { Support }\end{array}$ & 10.0 & $\begin{array}{l}\text { Richard } \\
\text { O'Connor }\end{array}$ & $\begin{array}{l}\text { Reid, Quebec, } \\
\text { Allison \& } \\
\text { Wilcox } \\
\text { Corporation }\end{array}$ \\
\hline
\end{tabular}


Table 3.6 Listing of Case History Review: Indiana (Cont'd)

\begin{tabular}{|c|c|c|c|c|c|c|}
\hline ID & Name & Type & Support & $\mathbf{H}(\mathrm{m})$ & $\begin{array}{l}\text { Contact } \\
\text { Name }\end{array}$ & Company \\
\hline 8 & $\begin{array}{l}\text { Indianapolis } \\
\text { Boulevard } \\
\text { Interchange } \\
\text { Modification }\end{array}$ & $\begin{array}{l}\text { Mechanically } \\
\text { Stabilized } \\
\text { Earth }\end{array}$ & $\begin{array}{l}\text { No } \\
\text { Additional } \\
\text { Support }\end{array}$ & 10.0 & $\begin{array}{l}\text { Richard } \\
\text { O'Connor }\end{array}$ & $\begin{array}{l}\text { Reid, Quebec, } \\
\text { Allison \& } \\
\text { Wilcox } \\
\text { Corporation }\end{array}$ \\
\hline 9 & $\begin{array}{l}\text { Kennedy } \\
\text { Avenue } \\
\text { Interchange } \\
\text { Modification }\end{array}$ & $\begin{array}{l}\text { Mechanically } \\
\text { Stabilized } \\
\text { Earth }\end{array}$ & $\begin{array}{l}\text { No } \\
\text { Additional } \\
\text { Support }\end{array}$ & 10.0 & $\begin{array}{l}\text { Richard } \\
\text { O'Connor }\end{array}$ & $\begin{array}{l}\text { Reid, Quebec, } \\
\text { Allison \& } \\
\text { Wilcox } \\
\text { Corporation }\end{array}$ \\
\hline 10 & $\begin{array}{l}\text { IGS } \\
\text { Taylorsville } \\
\text { Rest Area }\end{array}$ & Soil Nailing & $\begin{array}{l}\text { No } \\
\text { Additional } \\
\text { Support }\end{array}$ & 5.0 & $\begin{array}{l}\text { Richard } \\
\text { O'Connor }\end{array}$ & $\begin{array}{l}\text { Reid, Quebec, } \\
\text { Allison \& } \\
\text { Wilcox } \\
\text { Corporation }\end{array}$ \\
\hline 11 & $\begin{array}{l}\text { Indiana } \\
\text { Oxygen } \\
\text { Retaining } \\
\text { Wall, Beach } \\
\text { Grove }\end{array}$ & $\begin{array}{l}\text { Mechanically } \\
\text { Stabilized } \\
\text { Earth }\end{array}$ & $\begin{array}{l}\text { No } \\
\text { Additional } \\
\text { Support }\end{array}$ & 2.4 & $\begin{array}{l}\mathrm{Al} \\
\text { Kovacs }\end{array}$ & $\begin{array}{l}\text { ARSEE } \\
\text { Engineers }\end{array}$ \\
\hline 12 & $\begin{array}{l}\text { Target, New } \\
\text { Albany }\end{array}$ & Gabion & $\begin{array}{l}\text { No } \\
\text { Additional } \\
\text { Support }\end{array}$ & 4.6 & $\begin{array}{l}\mathrm{Al} \\
\text { Kovacs }\end{array}$ & $\begin{array}{l}\text { ARSEE } \\
\text { Engineers }\end{array}$ \\
\hline 13 & $\begin{array}{l}\text { Lower Canal } \\
\text { Improvements, } \\
\text { Indianapolis }\end{array}$ & Cantilever & $\begin{array}{l}\text { No } \\
\text { Additional } \\
\text { Support }\end{array}$ & 3.6 & $\begin{array}{l}\mathrm{Al} \\
\text { Kovacs }\end{array}$ & $\begin{array}{l}\text { ARSEE } \\
\text { Engineers }\end{array}$ \\
\hline 14 & $\begin{array}{l}\text { Circle Center } \\
\text { Mall, } \\
\text { Indianapolis }\end{array}$ & Sheet Piles & Other & 1.5 & $\begin{array}{l}\mathrm{Al} \\
\text { Kovacs }\end{array}$ & $\begin{array}{l}\text { ARSEE } \\
\text { Engineers }\end{array}$ \\
\hline 15 & $\begin{array}{l}\text { Hebrew } \\
\text { National } \\
\text { Foods, } \\
\text { Indianapolis } \\
\end{array}$ & $\begin{array}{l}\text { Pre-Cast } \\
\text { Concrete }\end{array}$ & $\begin{array}{l}\text { No } \\
\text { Additional } \\
\text { Support }\end{array}$ & 1.2 & $\begin{array}{l}\mathrm{Al} \\
\text { Kovacs }\end{array}$ & $\begin{array}{l}\text { ARSEE } \\
\text { Engineers }\end{array}$ \\
\hline 16 & $\begin{array}{l}\text { I-465 Over I- } \\
70 \text { Temporary } \\
\text { Bent, } \\
\text { Indianapolis }\end{array}$ & Sheet Piles & Tieback & 7.3 & $\begin{array}{l}\mathrm{Al} \\
\text { Kovacs }\end{array}$ & $\begin{array}{l}\text { ARSEE } \\
\text { Engineers }\end{array}$ \\
\hline 17 & GM, Bedford & Sheet Piles & Tieback & 4.6 & $\begin{array}{l}\mathrm{Al} \\
\text { Kovacs }\end{array}$ & $\begin{array}{l}\text { ARSEE } \\
\text { Engineers }\end{array}$ \\
\hline
\end{tabular}


Table 3.6 Listing of Case History Review: Indiana (Cont'd)

\begin{tabular}{|c|c|c|c|c|c|c|}
\hline ID & Name & Type & Support & H (m) & $\begin{array}{l}\text { Contact } \\
\text { Name }\end{array}$ & Company \\
\hline 18 & $\begin{array}{l}\text { Burdsal } \\
\text { Parkway } \\
\text { Bridge, } \\
\text { Indianapolis }\end{array}$ & Sheet Piles & $\begin{array}{l}\text { No } \\
\text { Additional } \\
\text { Support }\end{array}$ & 2.1 & $\begin{array}{l}\text { Al } \\
\text { Kovacs }\end{array}$ & $\begin{array}{l}\text { ARSEE } \\
\text { Engineers }\end{array}$ \\
\hline 19 & $\begin{array}{l}\text { Allisonville } \\
\text { Road } \\
\text { Widening }\end{array}$ & $\begin{array}{l}\text { Mechanically } \\
\text { Stabilized } \\
\text { Earth }\end{array}$ & $\begin{array}{l}\text { No } \\
\text { Additional } \\
\text { Support }\end{array}$ & 3.0 & $\begin{array}{l}\text { Bill } \\
\text { Chappell }\end{array}$ & $\begin{array}{l}\text { City of } \\
\text { Indianapolis }\end{array}$ \\
\hline 20 & $\begin{array}{l}\text { 86th Street } \\
\text { from Overlook } \\
\text { Parkway to } \\
\text { Meridian } \\
\text { Street }\end{array}$ & $\begin{array}{l}\text { Mechanically } \\
\text { Stabilized } \\
\text { Earth }\end{array}$ & $\begin{array}{l}\text { No } \\
\text { Additional } \\
\text { Support }\end{array}$ & 3.3 & $\begin{array}{l}\text { Bill } \\
\text { Chappell }\end{array}$ & $\begin{array}{l}\text { City of } \\
\text { Indianapolis }\end{array}$ \\
\hline 21 & $\begin{array}{l}\text { 86th Street } \\
\text { from Purdue } \\
\text { Road to Ditch } \\
\text { Road }\end{array}$ & Cantilever & $\begin{array}{l}\text { No } \\
\text { Additional } \\
\text { Support }\end{array}$ & 4.2 & $\begin{array}{l}\text { Bill } \\
\text { Chappell }\end{array}$ & $\begin{array}{l}\text { City of } \\
\text { Indianapolis }\end{array}$ \\
\hline 22 & $\begin{array}{l}\text { South Wall, } \\
\text { Bridge over } \\
\text { Minnow } \\
\text { Creek, NHS } \\
\text { US 24, } \\
\text { Laporte } \\
\text { District, Cass } \\
\text { County }\end{array}$ & $\begin{array}{l}\text { Mechanically } \\
\text { Stabilized } \\
\text { Earth }\end{array}$ & $\begin{array}{l}\text { No } \\
\text { Additional } \\
\text { Support }\end{array}$ & 16.9 & $\begin{array}{l}\text { Gregory } \\
\text { Pankow }\end{array}$ & $\begin{array}{l}\text { Indiana } \\
\text { Department of } \\
\text { Transportation }\end{array}$ \\
\hline 23 & $\begin{array}{l}\text { North Wall, } \\
\text { Bridge over } \\
\text { Minnow } \\
\text { Creek, NHS } \\
\text { US 24, } \\
\text { Laporte } \\
\text { District, Cass } \\
\text { County }\end{array}$ & $\begin{array}{l}\text { Mechanically } \\
\text { Stabilized } \\
\text { Earth }\end{array}$ & $\begin{array}{l}\text { No } \\
\text { Additional } \\
\text { Support }\end{array}$ & 15.5 & $\begin{array}{l}\text { Gregory } \\
\text { Pankow }\end{array}$ & $\begin{array}{l}\text { Indiana } \\
\text { Department of } \\
\text { Transportation }\end{array}$ \\
\hline 24 & $\begin{array}{l}\text { South Wall, } \\
\text { WINAMAC } \\
\text { Railroad } \\
\text { Crossing, } \\
\text { NHS US 24, } \\
\text { Laporte } \\
\text { District, Cass } \\
\text { County }\end{array}$ & $\begin{array}{l}\text { Mechanically } \\
\text { Stabilized } \\
\text { Earth }\end{array}$ & $\begin{array}{l}\text { No } \\
\text { Additional } \\
\text { Support }\end{array}$ & 9.4 & $\begin{array}{l}\text { Gregory } \\
\text { Pankow }\end{array}$ & $\begin{array}{l}\text { Indiana } \\
\text { Department of } \\
\text { Transportation }\end{array}$ \\
\hline
\end{tabular}


Table 3.6 Listing of Case History Review: Indiana (Cont'd)

\begin{tabular}{|c|c|c|c|c|c|c|}
\hline ID & Name & Type & Support & $\mathbf{H}(\mathrm{m})$ & $\begin{array}{l}\text { Contact } \\
\text { Name }\end{array}$ & Company \\
\hline 25 & $\begin{array}{l}\text { North Wall, } \\
\text { WINAMAC } \\
\text { Railroad } \\
\text { Crossing, } \\
\text { NHS US 24, } \\
\text { Laporte } \\
\text { District, Cass } \\
\text { County }\end{array}$ & $\begin{array}{l}\text { Mechanically } \\
\text { Stabilized } \\
\text { Earth }\end{array}$ & $\begin{array}{l}\text { No } \\
\text { Additional } \\
\text { Support }\end{array}$ & 9.6 & $\begin{array}{l}\text { Gregory } \\
\text { Pankow }\end{array}$ & $\begin{array}{l}\text { Indiana } \\
\text { Department of } \\
\text { Transportation }\end{array}$ \\
\hline 26 & $\begin{array}{l}\text { Stone Wall, } \\
\text { Columbia } \\
\text { Avenue, } \\
\text { Munster, Lake } \\
\text { County }\end{array}$ & Masonry & $\begin{array}{l}\text { No } \\
\text { Additional } \\
\text { Support }\end{array}$ & 1.2 & $\begin{array}{l}\text { Gregory } \\
\text { Pankow }\end{array}$ & $\begin{array}{l}\text { Indiana } \\
\text { Department of } \\
\text { Transportation }\end{array}$ \\
\hline 27 & $\begin{array}{l}\text { SBR Ramp, } \\
\text { East Chicago } \\
\text { Marina Access } \\
\text { Road, Lake } \\
\text { County }\end{array}$ & $\begin{array}{l}\text { Mechanically } \\
\text { Stabilized } \\
\text { Earth }\end{array}$ & $\begin{array}{l}\text { No } \\
\text { Additional } \\
\text { Support }\end{array}$ & 8.4 & $\begin{array}{l}\text { Gregory } \\
\text { Pankow }\end{array}$ & $\begin{array}{l}\text { Indiana } \\
\text { Department of } \\
\text { Transportation }\end{array}$ \\
\hline 28 & $\begin{array}{l}\text { NBR Ramp, } \\
\text { East Chicago } \\
\text { Marina Access } \\
\text { Road, Lake } \\
\text { County }\end{array}$ & $\begin{array}{l}\text { Mechanically } \\
\text { Stabilized } \\
\text { Earth }\end{array}$ & $\begin{array}{l}\text { No } \\
\text { Additional } \\
\text { Support }\end{array}$ & 6.8 & $\begin{array}{l}\text { Gregory } \\
\text { Pankow }\end{array}$ & $\begin{array}{l}\text { Indiana } \\
\text { Department of } \\
\text { Transportation }\end{array}$ \\
\hline 29 & $\begin{array}{l}\text { V Ramp, East } \\
\text { Chicago } \\
\text { Marina Access } \\
\text { Road, Lake } \\
\text { County }\end{array}$ & $\begin{array}{l}\text { Mechanically } \\
\text { Stabilized } \\
\text { Earth }\end{array}$ & $\begin{array}{l}\text { No } \\
\text { Additional } \\
\text { Support }\end{array}$ & 10.6 & $\begin{array}{l}\text { Gregory } \\
\text { Pankow }\end{array}$ & $\begin{array}{l}\text { Indiana } \\
\text { Department of } \\
\text { Transportation }\end{array}$ \\
\hline 30 & $\begin{array}{l}\text { MB-NBR-V } \\
\text { Ramp, East } \\
\text { Chicago } \\
\text { Marina Access } \\
\text { Road, Lake } \\
\text { County } \\
\end{array}$ & $\begin{array}{l}\text { Mechanically } \\
\text { Stabilized } \\
\text { Earth }\end{array}$ & $\begin{array}{l}\text { No } \\
\text { Additional } \\
\text { Support }\end{array}$ & 10.0 & $\begin{array}{l}\text { Gregory } \\
\text { Pankow }\end{array}$ & $\begin{array}{l}\text { Indiana } \\
\text { Department of } \\
\text { Transportation }\end{array}$ \\
\hline 31 & $\begin{array}{l}\text { I- } 80 \text { MSE } \\
\text { South Wall, } \\
\text { Gary, Lake } \\
\text { County }\end{array}$ & $\begin{array}{l}\text { Mechanically } \\
\text { Stabilized } \\
\text { Earth }\end{array}$ & $\begin{array}{l}\text { No } \\
\text { Additional } \\
\text { Support }\end{array}$ & 7.3 & $\begin{array}{l}\text { Gregory } \\
\text { Pankow }\end{array}$ & $\begin{array}{l}\text { Indiana } \\
\text { Department of } \\
\text { Transportation }\end{array}$ \\
\hline
\end{tabular}


Table 3.6 Listing of Case History Review: Indiana (Cont'd)

\begin{tabular}{|c|c|c|c|c|c|c|}
\hline ID & Name & Type & Support & $\mathbf{H}(\mathbf{m})$ & $\begin{array}{l}\text { Contact } \\
\text { Name }\end{array}$ & Company \\
\hline 32 & $\begin{array}{l}\text { I-80 MSE } \\
\text { North Wall, } \\
\text { Gary, Lake } \\
\text { County }\end{array}$ & $\begin{array}{l}\text { Mechanically } \\
\text { Stabilized } \\
\text { Earth }\end{array}$ & $\begin{array}{l}\text { No } \\
\text { Additional } \\
\text { Support }\end{array}$ & 6.2 & $\begin{array}{l}\text { Gregory } \\
\text { Pankow }\end{array}$ & $\begin{array}{l}\text { Indiana } \\
\text { Department of } \\
\text { Transportation }\end{array}$ \\
\hline 33 & $\begin{array}{l}\text { I-80, Clarke } \\
\text { St., Gary, } \\
\text { Lake County }\end{array}$ & Soldier Piles & Tieback & 6.3 & $\begin{array}{l}\text { Gregory } \\
\text { Pankow }\end{array}$ & $\begin{array}{l}\text { Indiana } \\
\text { Department of } \\
\text { Transportation }\end{array}$ \\
\hline 34 & $\begin{array}{l}\text { I465, South } \\
\text { MSE Wall, } \\
\text { Bent } 1 \\
\text { NBSRX, } \\
\text { Marion } \\
\text { County }\end{array}$ & $\begin{array}{l}\text { Mechanically } \\
\text { Stabilized } \\
\text { Earth }\end{array}$ & $\begin{array}{l}\text { No } \\
\text { Additional } \\
\text { Support }\end{array}$ & 8.5 & $\begin{array}{l}\text { Gregory } \\
\text { Pankow }\end{array}$ & $\begin{array}{l}\text { Indiana } \\
\text { Department of } \\
\text { Transportation }\end{array}$ \\
\hline 35 & $\begin{array}{l}\text { I465, North } \\
\text { MSE Wall, } \\
\text { Bent } 3 \\
\text { NBSRX, } \\
\text { Marion } \\
\text { County }\end{array}$ & $\begin{array}{l}\text { Mechanically } \\
\text { Stabilized } \\
\text { Earth }\end{array}$ & $\begin{array}{l}\text { No } \\
\text { Additional } \\
\text { Support }\end{array}$ & 11.5 & $\begin{array}{l}\text { Gregory } \\
\text { Pankow }\end{array}$ & $\begin{array}{l}\text { Indiana } \\
\text { Department of } \\
\text { Transportation }\end{array}$ \\
\hline 36 & $\begin{array}{l}\text { I465, North } \\
\text { MSE Wall, } \\
\text { Bent } 1 \\
\text { NBSRX, } \\
\text { Marion } \\
\text { County }\end{array}$ & $\begin{array}{l}\text { Mechanically } \\
\text { Stabilized } \\
\text { Earth }\end{array}$ & $\begin{array}{l}\text { No } \\
\text { Additional } \\
\text { Support }\end{array}$ & 12.7 & $\begin{array}{l}\text { Gregory } \\
\text { Pankow }\end{array}$ & $\begin{array}{l}\text { Indiana } \\
\text { Department of } \\
\text { Transportation }\end{array}$ \\
\hline 37 & $\begin{array}{l}\text { I465, North } \\
\text { Soil Nail Wall, } \\
\text { over } \\
\text { Brookeville } \\
\text { rd, Marion } \\
\text { County }\end{array}$ & Soil Nailing & $\begin{array}{l}\text { No } \\
\text { Additional } \\
\text { Support }\end{array}$ & 3.7 & $\begin{array}{l}\text { Gregory } \\
\text { Pankow }\end{array}$ & $\begin{array}{l}\text { Indiana } \\
\text { Department of } \\
\text { Transportation }\end{array}$ \\
\hline 38 & $\begin{array}{l}\text { I465, South } \\
\text { Soil Nail Wall, } \\
\text { over } \\
\text { Brookeville } \\
\text { rd, Marion } \\
\text { County }\end{array}$ & Soil Nailing & $\begin{array}{l}\text { No } \\
\text { Additional } \\
\text { Support }\end{array}$ & 4.0 & $\begin{array}{l}\text { Gregory } \\
\text { Pankow }\end{array}$ & $\begin{array}{l}\text { Indiana } \\
\text { Department of } \\
\text { Transportation }\end{array}$ \\
\hline
\end{tabular}


Table 3.6 Listing of Case History Review: Indiana (Cont'd)

\begin{tabular}{|c|c|c|c|c|c|c|}
\hline ID & Name & Type & Support & H (m) & $\begin{array}{l}\text { Contact } \\
\text { Name }\end{array}$ & Company \\
\hline 39 & $\begin{array}{l}\text { Bin Wall A, } \\
\text { 5th Ave, } \\
\text { Evansville, } \\
\text { Vanderburgh } \\
\text { County }\end{array}$ & Crib/Bin & $\begin{array}{l}\text { No } \\
\text { Additional } \\
\text { Support }\end{array}$ & 2.9 & $\begin{array}{l}\text { Gregory } \\
\text { Pankow }\end{array}$ & $\begin{array}{l}\text { Indiana } \\
\text { Department of } \\
\text { Transportation }\end{array}$ \\
\hline 40 & $\begin{array}{l}\text { Bin Wall B, } \\
\text { 5th Ave, } \\
\text { Evansville, } \\
\text { Vanderburgh } \\
\text { County }\end{array}$ & Crib/Bin & $\begin{array}{l}\text { No } \\
\text { Additional } \\
\text { Support }\end{array}$ & 3.8 & $\begin{array}{l}\text { Gregory } \\
\text { Pankow }\end{array}$ & $\begin{array}{l}\text { Indiana } \\
\text { Department of } \\
\text { Transportation }\end{array}$ \\
\hline 41 & $\begin{array}{l}\text { Fulton Ave } \\
\text { Bridge over } \\
\text { Pidgeon } \\
\text { Creek, } \\
\text { Evansville, } \\
\text { Vanderburgh } \\
\text { County }\end{array}$ & Soldier Piles & Tieback & 9.1 & $\begin{array}{l}\text { Gregory } \\
\text { Pankow }\end{array}$ & $\begin{array}{l}\text { Indiana } \\
\text { Department of } \\
\text { Transportation }\end{array}$ \\
\hline
\end{tabular}

\subsubsection{Support Tables}

A total of twelve (12) support tables give customized choices to some of the fields of the CHR tables. This is done with "lookups" set in the fields of the CHR tables. The lookups provide a finite, well-defined, number of choices associated with the particular field. This narrows down the options for those fields and makes it easier to correlate parameters. Table 3.7 shows the tables names and their purpose. Table "Books: References" keeps the list of journals, conferences and books used for the project. Table "Books: Use" gives a choice list for the Table "Books: References" to assign the use that was given to the books (design, case history reference, etc.). Table "Contacts: General" has the contact 
information of the designers and contractors who participated in the survey. Every "Types" table has customized choice lists for the CHR tables. The speed of the lookups is greatly improved if relationships between the tables are established. Figure 3.5 shows all relationships between the support tables of the database, the CHR tables and their fields. All the relationships are one to many

Table 3.7 Support Tables

\begin{tabular}{|l|l|}
\hline Table & Purpose \\
\hline Books: References & Keeps records of the books used \\
\hline Books: Use & $\begin{array}{l}\text { Gives the type of use given to the books on the table } \\
\text { 'Books: References" }\end{array}$ \\
\hline Contacts: General & $\begin{array}{l}\text { Information of the designers and contractors who } \\
\text { submitted data }\end{array}$ \\
\hline Types: Additional Support & Customized categories of additional support \\
\hline Types: Item & Links INDOT's bidding Items to research classification \\
\hline Types: Locations & Customized categories of geographic locations \\
\hline Types: Retaining Structure & $\begin{array}{l}\text { Customized categories of type of retaining devices (based } \\
\text { O' Rourke) }\end{array}$ \\
\hline $\begin{array}{l}\text { Types: Retaining Structure: } \\
\text { Breakdown }\end{array}$ & $\begin{array}{l}\text { Customized categories of classification of retaining } \\
\text { devices (adopted) }\end{array}$ \\
\hline $\begin{array}{l}\text { Types: Retaining Structure: } \\
\text { Classification }\end{array}$ & $\begin{array}{l}\text { Customized categories of classification of retaining } \\
\text { devices based on stabilization systems (based O' Rourke) }\end{array}$ \\
\hline Types: Soil & $\begin{array}{l}\text { Customized categories of soil description (based Terzaghi } \\
\text { and Peck) }\end{array}$ \\
\hline Types: Soil - Description & Customized categories of source of soil description \\
\hline Types: Walls' Status & Customized categories of status of the wall \\
\hline
\end{tabular}

\section{$3.5 \underline{\text { Forms }}$}

Forms are MSA objects that are used to add, view, and edit the data stored in tables. Two forms have been created for quick input and access to the CHR tables: Forms Case History Review: Literature; and Case History Review: Indiana. The forms are included in Figure 3.6 and Figure 3.7 respectively. The figures show the forms as they appear on 
screen. These forms are just a different way to manipulate the data from the CHR tables. The information shown represents a record and each box represents a field. The customized choice lists from the support tables appear by clicking on the arrows located next to each field, as indicated in the Figure. To fill out, modify or delete information from a record, just move the mouse to the field and type the changes. The navigation buttons located at the bottom left of the image can be used to change records.

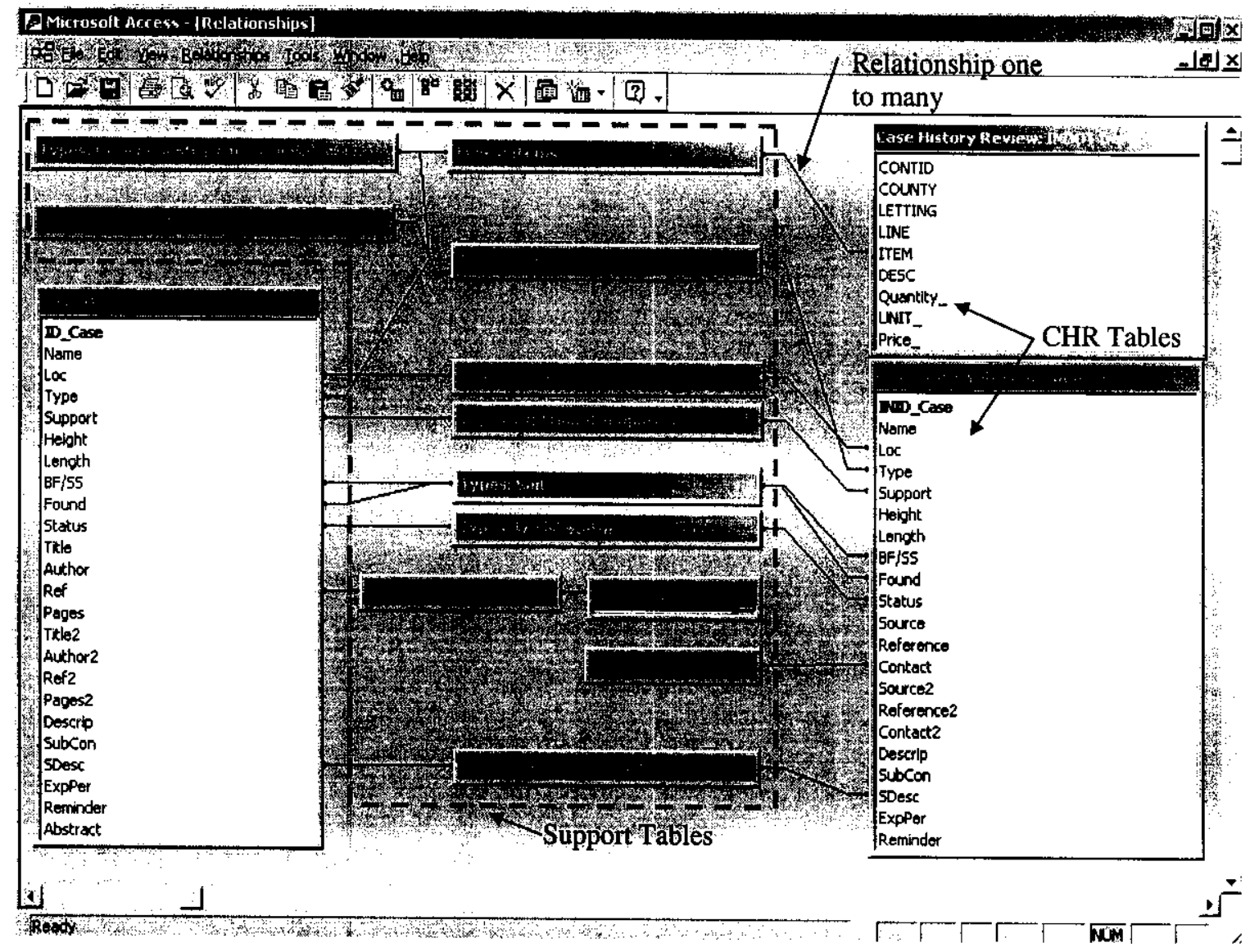

Figure 3.5 Tables' Relationships 


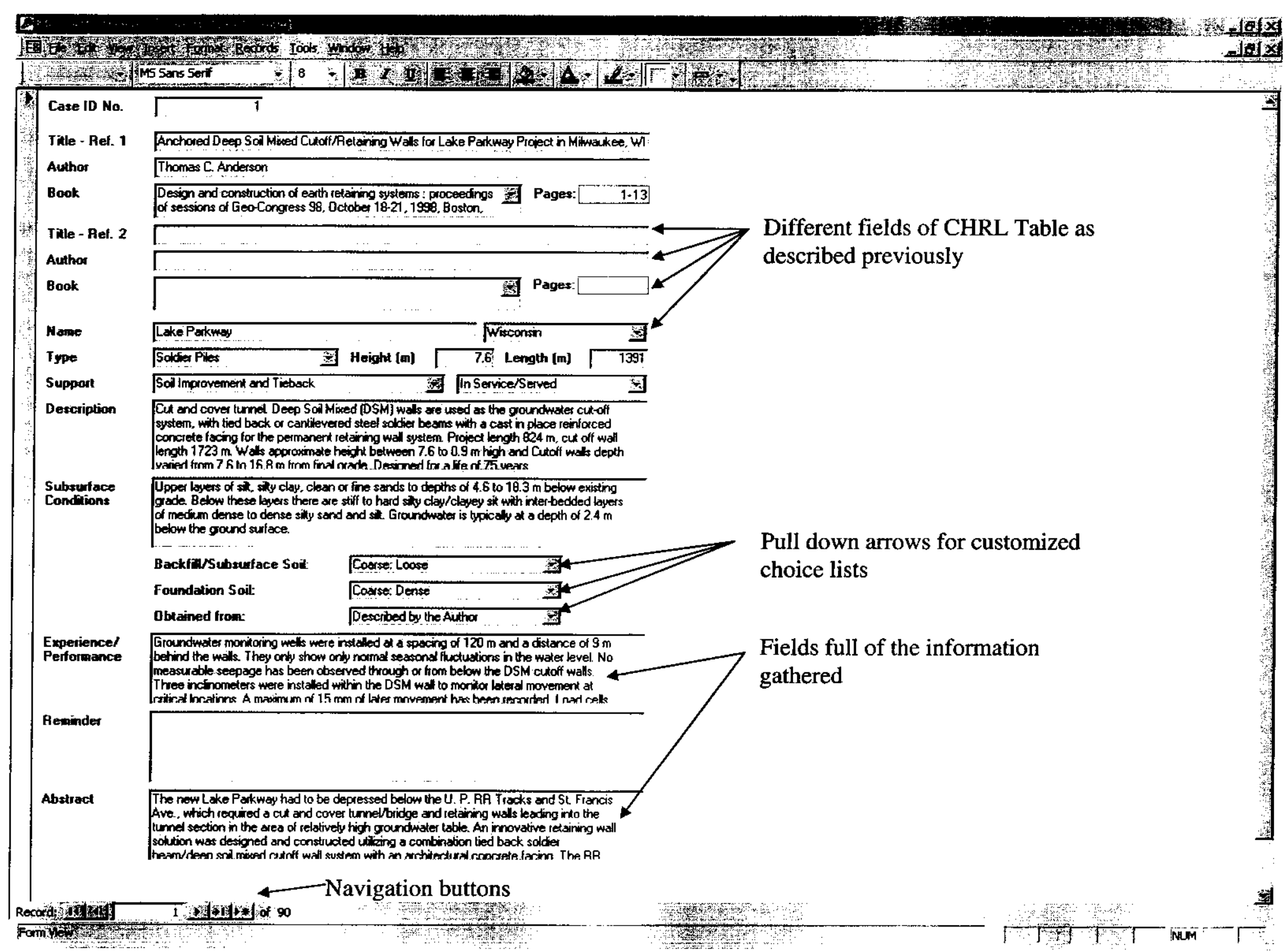

Figure 3.6 Form Case History Review: Literature 

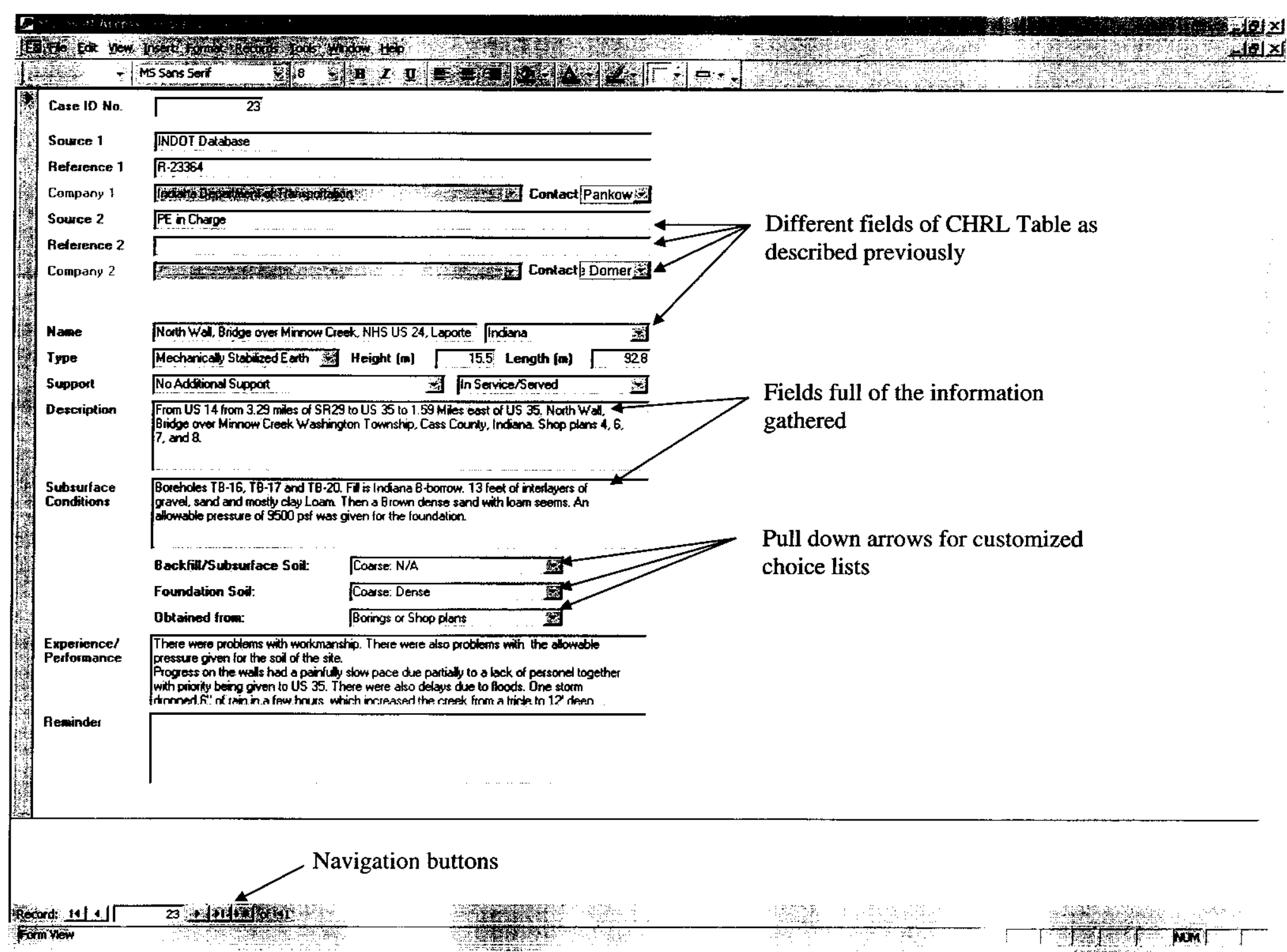

Figure 3.7 Form Case History Review: Indiana 


\subsection{Queries and Reports}

Specific queries and reports objects are created in the database; some of them are used to create different tables for this document (e.g. Table 3.2), to aid in the analysis of the information, or to correlate the information. Figure 3.8 and Figure 3.9 show two queries performed on the CHR tables. The column RClass has the fields of the customized list for retaining device categories used in the CHR tables and the column CountOfRClass presents the total of cases for each type of wall. This is an example of the use of queries to analyze the data stored in the database. Names of the queries and reports are selfexplanatory. Whenever a report or query is used for the analysis through this document it is referenced.

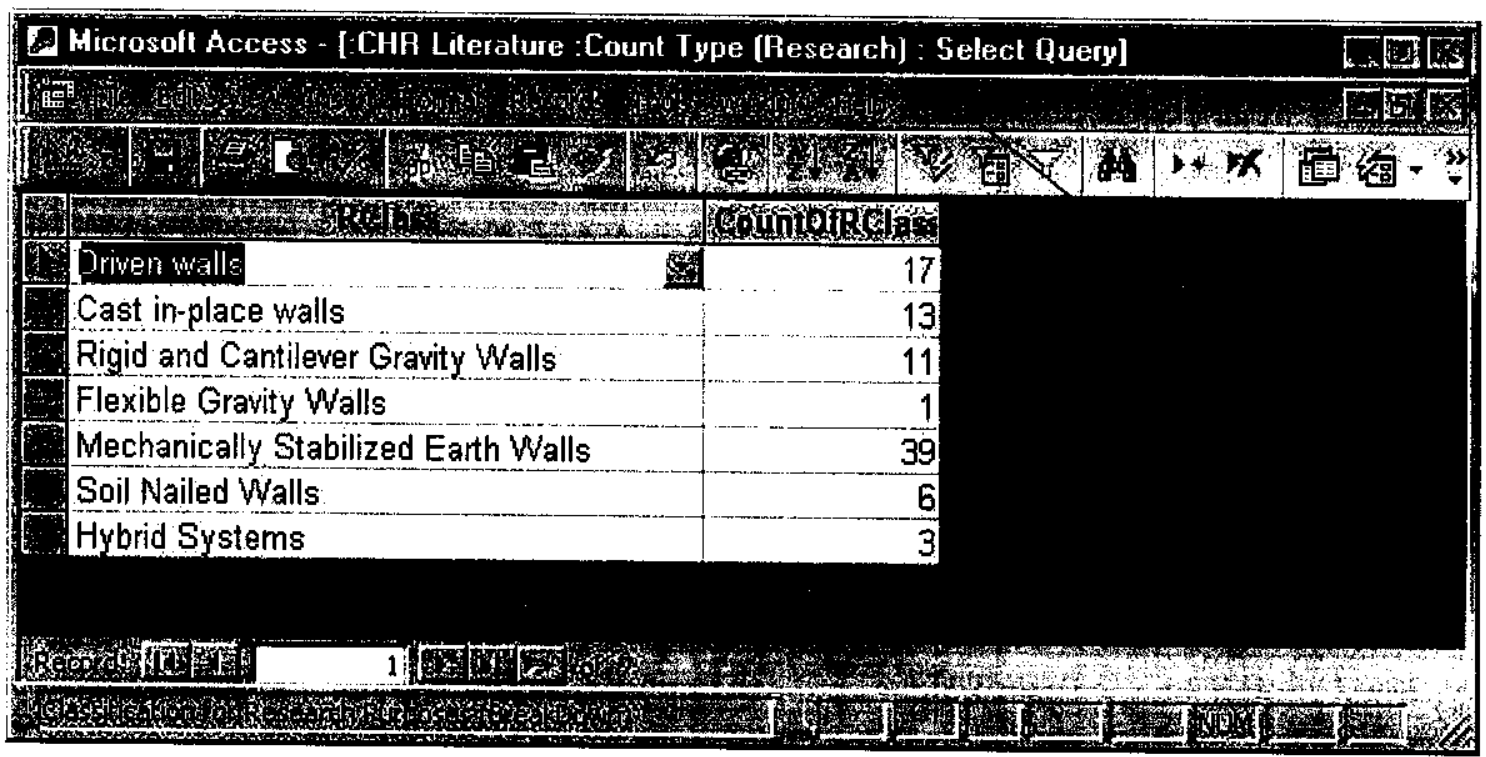

Figure 3.8 Select Query Example, :CHR Literature :Count Type Research 


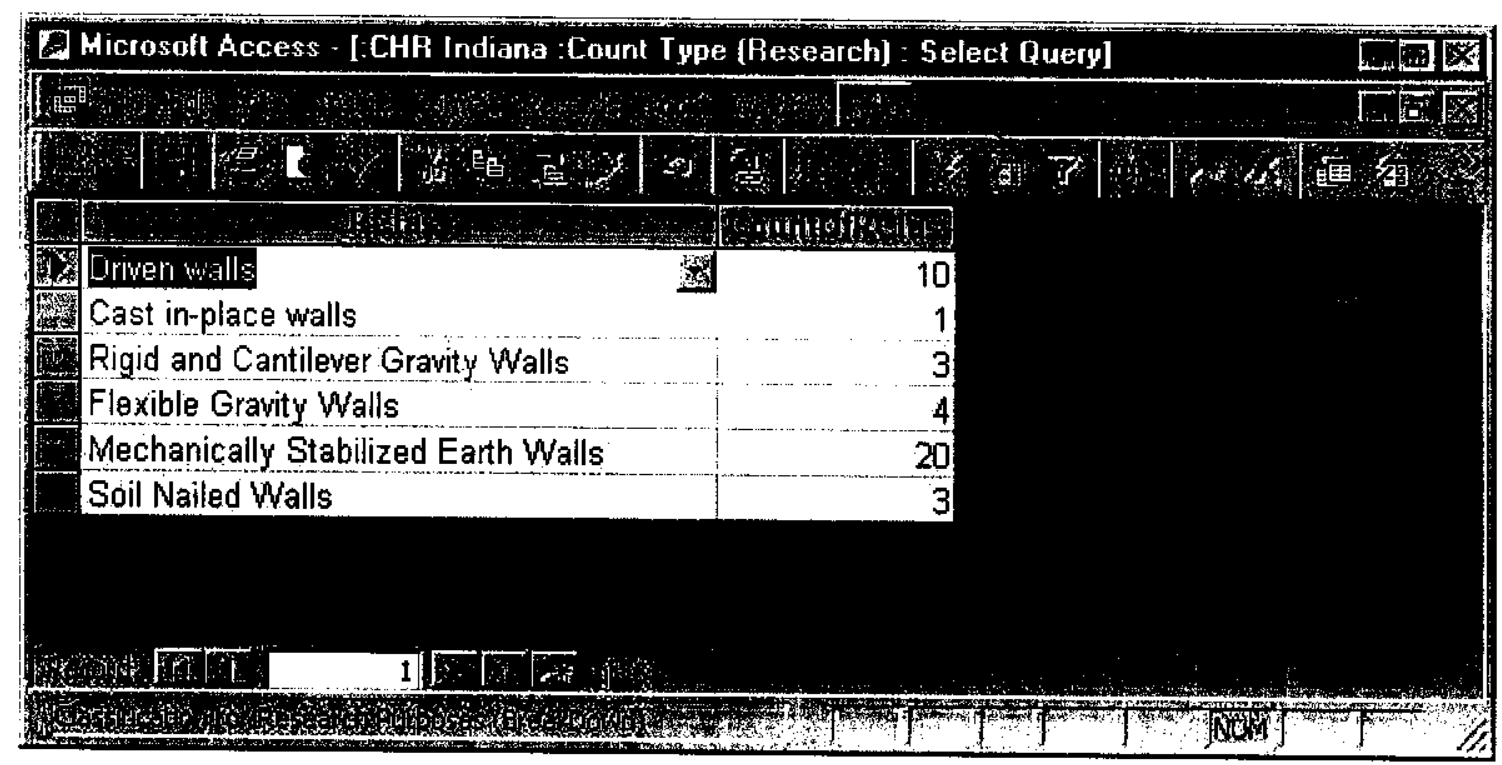

Figure 3.9 Select Query Example, :CHR Indiana :Count Type Research

\subsection{Database Categories Layout}

\subsubsection{Sub-Soil Types}

Each of the CHR tables of the database has two fields for soil descriptions: BF/SS and Found. In these fields a choice is selected from a previously established list located in the support table Types: Soil (Table 3.7); the choices are shown in Table 3.8. One of the fields, BF/SS, is for backfill or subsoil. In this field a soil classification is selected for backfill, in the case where the retaining device analyzed is a fill, and subsoil in case it is a cut. The other field, Found, for foundation soil is used to input information about the subsoil below the device.

Table Types: Soil contains the soil classification used for this research. Correlations of SPT blow count with density of sands and strength of clays are used. Terzaghi and Peck 
correlations, the most commonly used in practice, are shown in Table 3.8. These correlations are selected because they are highly used in practice and a large amount of correlations with other soil properties exists in the literature. All the correlations used in the database are shown in Table 3.8 next to their corresponding soil type in the support table "Types: Soil".

Table 3.8 Soil Types Used in Database

\begin{tabular}{|c|c|c|c|c|c|}
\hline Types: Soil & \multicolumn{5}{|c|}{ Criteria } \\
\hline \multirow[t]{2}{*}{ Based on: } & \multicolumn{5}{|c|}{ Peck et. all, 1974} \\
\hline & $\mathbf{N}$ (SPT) & $\phi($ TX C) & $\phi($ TX E) & $\phi($ PS C) & $\phi($ PS E) \\
\hline Coarse: Very Loose & $<4$ & $<27$ & $<30$ & $<30$ & $<34$ \\
\hline Coarse: Loose & $4-10$ & $27-28$ & $30-31$ & $30-31$ & $34-35$ \\
\hline Coarse: Medium Dense & $10-30$ & $28-32$ & $31-36$ & $31-36$ & $35-40$ \\
\hline Coarse: Dense & $30-50$ & $32-36$ & $36-40$ & $36-40$ & $40-45$ \\
\hline Coarse: Very Dense & $>50$ & $>36$ & $>40$ & $>40$ & $>45$ \\
\hline Coarse: N/A & \multicolumn{5}{|c|}{ No information available for further classification } \\
\hline \multirow{2}{*}{ Based on: } & \multicolumn{5}{|c|}{ Terzaghi and Peck, 1948} \\
\hline & \multicolumn{3}{|c|}{ N (SPT blow count) } & \multicolumn{2}{|c|}{ UCS (tsf) } \\
\hline Fine: Very Soft & \multicolumn{3}{|c|}{2} & \multicolumn{2}{|c|}{$<0.25$} \\
\hline Fine: Soft & \multicolumn{3}{|c|}{$2-4$} & \multicolumn{2}{|c|}{$0.25-0.50$} \\
\hline Fine: Medium Stiff & \multicolumn{3}{|c|}{$4-8$} & \multicolumn{2}{|c|}{$0.50-1.00$} \\
\hline Fine: Stiff & \multicolumn{3}{|c|}{$8-15$} & \multicolumn{2}{|c|}{$1.00-2.00$} \\
\hline Fine: Very Stiff & \multicolumn{3}{|c|}{$15-30$} & \multicolumn{2}{|c|}{$2.00-4.00$} \\
\hline Fine: Hard & \multicolumn{3}{|c|}{$>30$} & \multicolumn{2}{|c|}{$>4.00$} \\
\hline Fine: N/A & \multicolumn{5}{|c|}{ No information available for further classification } \\
\hline Rock & \multicolumn{5}{|c|}{ Considered as a suitable strong material } \\
\hline Other & \multicolumn{5}{|c|}{ On other structure/over-excavated/other } \\
\hline N/A & \multicolumn{5}{|c|}{ No information available for further classification } \\
\hline \multicolumn{6}{|c|}{$\begin{array}{l}\text { where: } \\
\text { UCS = Unconfined Compressing Strength } \\
\text { TX C = Triaxial compression test } \\
\text { TX E = Triaxial extension test } \\
\text { PS C = Plane strain compression test } \\
\text { PS E = Plane strain extension test }\end{array}$} \\
\hline
\end{tabular}




\subsubsection{Retaining Device Type}

All of the CHR tables of the database have a field for retaining device type. It is vital to discern a proper classification for retaining devices. As discussed in chapter 2, O'Rourke provides a good classification. Support tables Types: Retaining Structures (TRS) and Types: Retaining Structures: Classification (TRSC) provide a list of choices available according to that classification (Figure 2.1). Support table Types: Retaining Structures: Breakdown (TRSB) has our modified classification (Figure 2.25). Table 3.9 shows the retaining device types with its corresponding classification. The retaining device column corresponds to the support table TRS, the type column, to TRSB; and, the classification column to TRSC. While filling out a case history record a choice list from the TRS table is used. However, at any point correlations can be made with any of the other two columns without having to specify the type or classification for each case.

\subsubsection{Additional Support}

In some cases, the choice of retaining device is not enough to maintain stability. In those cases an additional support can be applied to make the device stable. Different types of support techniques are available to improve stability, and even sometimes, different methods are used simultaneously. These retaining devices are described in Section 2.3.1.3. Table 3.10 presents the types of additional support encountered in this research. This is the list of choices available from the support table of the database: Types: Additional Support. 
Table 3.9 Retaining Device Types Used on Database

\begin{tabular}{|c|c|c|}
\hline Retaining Device & Type & Classification \\
\hline Pre-Cast Concrete & \multirow{4}{*}{ Driven walls } & \multirow{8}{*}{ In-Situ Walls: ESS } \\
\hline Sheet Piles & & \\
\hline Soldier Piles & & \\
\hline Bored-in-place & & \\
\hline Cast in-situ & \multirow{2}{*}{ Cast in-place walls } & \\
\hline Soil-Cement & & \\
\hline Braced & \multirow[t]{2}{*}{ Additional Support } & \\
\hline Tieback & & \\
\hline Masonry & \multirow{5}{*}{$\begin{array}{l}\text { Rigid and Cantilever } \\
\text { Gravity Walls }\end{array}$} & \multirow[t]{7}{*}{ Gravity Walls: ESS } \\
\hline Concrete & & \\
\hline Cantilever & & \\
\hline Counterfort & & \\
\hline Cellular Cofferdam & & \\
\hline Gabion & \multirow{2}{*}{ Flexible Gravity Walls } & \\
\hline Crib/Bin & & \\
\hline $\begin{array}{l}\text { Mechanically Stabilized } \\
\text { Earth }\end{array}$ & \begin{tabular}{|l|} 
Mechanically \\
Stabilized Earth Walls
\end{tabular} & Reinforced Soils: ISS \\
\hline Soil Nailing & \multirow[t]{3}{*}{ Soil Nailed Walls } & \multirow[t]{3}{*}{ In-Situ Reinforcement: ISS } \\
\hline Reticulated Micro-Piles & & \\
\hline Soil Doweling & & \\
\hline Tailed gabions & \multirow[t]{2}{*}{ Hybrid Systems } & \multirow[t]{2}{*}{ Hybrid Systems: ESS \& ISS } \\
\hline Tailed Masonry & & \\
\hline N/A & \multicolumn{2}{|l|}{ No information available } \\
\hline
\end{tabular}

Table 3.10 Types: Additional Support

\begin{tabular}{|l|}
\hline \multicolumn{1}{|c|}{ Type } \\
\hline Braced \\
\hline Tieback \\
\hline Soil Nailing \\
\hline Soil Improvement \\
\hline Other \\
\hline No Additional Support \\
\hline Soil Improvement and Braced \\
\hline Soil Improvement and Tieback \\
\hline Soil Improvement and other \\
\hline
\end{tabular}




\subsection{Conclusions}

In this chapter, an overview of the basic database terminology and components is presented. A quick introduction to the functions of the software used, Microsoft Access, is provided through the use of various examples. The structure and layout of the electronic database created for the project is presented and each of its main components is fully explained. Views from different components are shown and the capabilities of the database are discussed. The database is a collection of information stored in an upgradeable electronic medium capable of quick correlation and analysis of its data.

A total of 207 cases are presented. They are divided in three tables: Case History Review: Literature, which contains 90 case histories from all over the world, Case History Review: INDOT's Database, which contains 76 cases with information of the cost of construction of walls built in Indiana, Case History Review: Indiana, which includes 41 cases from INDOT's database and from a survey of local contractors and engineers. This constitutes a dynamic database, which is easily upgradeable and provides a very effective means of cross-linking and referencing information. The potential cross-linking and analyzing the information stored is undeniable. 


\section{CHAPTER IV. SELECTION OF RETAINING DEVICES}

For a given project, the selection of the most suitable retaining device is a rather complex task involving a large number of variables. In the technical literature, many attempts can be found in order to recognize the different factors affecting the retaining device selection

(e.g. Munfakh, 1990 and Oliphant, 1997); a quantification of these factors is made by FHWA, 1995.

In this chapter, an overview of the FHWA recommendations and the specifications required in the State of Indiana are presented, as well as the key factors for each retaining device and the suggested selection procedure. Once the necessary provisions are established a comparison of the case histories gathered in the project electronic database (as described in the previous chapter) is made. This has proved useful in the development of guidelines for the selection of retaining devices.

\subsection{Federal Highway Administration recommendations}

The Federal Highway Administration (FHWA) report on Earth Retaining structures (FHWA, 1995) describes various retaining device systems and provides summaries of general information, advantages, disadvantages and additional comments for each wall. The general information includes: typical applications, special applications, unit cost 
range, items included in the unit cost, size requirements, and typical height range. The FHWA recommendations are presented in Table 4.1, Table 4.2, Table 4.3 and Table 4.4.

Table 4.1 Retaining device selection chart for fill walls (FHWA, 1995)

\begin{tabular}{|c|c|c|c|c|c|c|}
\hline Wall Type & $\stackrel{\dot{0}}{\dot{0}}$ & $\stackrel{\dot{\theta}}{\ddot{\theta}}$ & $\begin{array}{c}\text { Height } \\
\text { Effective } \\
\text { Cost Range }\end{array}$ & $\begin{array}{l}\text { Cost in } \$ \\
\text { per } \mathbf{m}^{2} \text { of } \\
\text { Wall }\end{array}$ & $\begin{array}{l}\text { Required } \\
\text { ROW }^{(2)}\end{array}$ & $\begin{array}{c}\text { Tolerable } \\
\text { Differential }^{(3)} \\
\text { Settlement }^{(3)}\end{array}$ \\
\hline $\begin{array}{l}\text { Masonry and } \\
\text { Concrete walls }\end{array}$ & $\sqrt{ }$ & & $1-3 m$ & $270-370$ & $0.5-0.7 \mathrm{H}^{(4)}$ & $1 / 500$ \\
\hline Cantilever walls & $\sqrt{ }$ & & $2-9 m$ & $270-650$ & $0.4-0.7 \mathrm{H}^{(4)}$ & $1 / 500$ \\
\hline Counterfort walls & $\sqrt{ }$ & & $9-18 m$ & $270-650$ & $0.4-0.7 \mathrm{H}^{(4)}$ & $1 / 500$ \\
\hline Crib walls & $\sqrt{ }$ & & $2-11 \mathrm{~m}$ & $270-380$ & $0.5-0.7 \mathrm{H}$ & $1 / 300$ \\
\hline Bin walls & $\sqrt{ }$ & & $2-11 \mathrm{~m}$ & $270-380$ & $0.5-0.7 \mathrm{H}$ & $1 / 300$ \\
\hline Gabion walls & $\sqrt{ }$ & $\sqrt{ }$ & $2-8 m$ & $270-540$ & $0.5-0.7 \mathrm{H}$ & $1 / 50$ \\
\hline $\begin{array}{l}\text { MSE walls } \\
\text { (pre-cast facing) }\end{array}$ & $\sqrt{ }$ & & $3-20 m$ & $240-380$ & $0.7-1.0 \mathrm{H}$ & $1 / 100$ \\
\hline $\begin{array}{l}\text { MSE walls } \\
\text { (modular block } \\
\text { facing) }\end{array}$ & $\sqrt{ }$ & & $2-11 \mathrm{~m}$ & $175-275$ & $0.7-1.0 \mathrm{H}$ & $1 / 200$ \\
\hline $\begin{array}{l}\text { MSE walls } \\
\text { (geotextile wire } \\
\text { fencing) }\end{array}$ & $\sqrt{ }$ & $\sqrt{ }$ & $2-15 \mathrm{~m}$ & $165-380$ & $0.7-1.0 \mathrm{H}$ & $1 / 60$ \\
\hline \multicolumn{7}{|c|}{$\begin{array}{l}\text { Notes: } \\
\text { (1) Total installed costs in } 1995 \text { US Dollars } \\
\text { (2) Right-of-way (ROW) requirements expressed as the distance (as a fraction of the } \\
\text { height of the wall, H) behind the wall face where fill placement is generally } \\
\text { required for flat backfill conditions, except where noted. } \\
\text { (3) Ratio of difference in vertical settlement between two points along the wall to the } \\
\text { horizontal distance between the points. } \\
\text { (4) Right-of-way (ROW) requirements is the typical wall base width as a fraction of } \\
\text { the wall height, H }\end{array}$} \\
\hline
\end{tabular}


Table 4.2 Retaining device selection chart for cut walls (FHWA, 1995)

\begin{tabular}{|c|c|c|c|c|c|c|c|}
\hline $\begin{array}{l}\text { Wall } \\
\text { Type }\end{array}$ & $\dot{\Xi}$ & 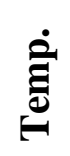 & $\begin{array}{c}\text { Height } \\
\text { Effective } \\
\text { Cost Range }\end{array}$ & $\begin{array}{c}\text { Cost in } \$ \\
\text { per } \mathbf{m}^{2} \text { of } \\
\text { Wall }\end{array}$ & $\begin{array}{l}\text { Required } \\
\text { ROW }^{(2)}\end{array}$ & $\begin{array}{c}\text { Lateral } \\
\text { Movements }\end{array}$ & $\begin{array}{c}\text { Water } \\
\text { Tightness }\end{array}$ \\
\hline $\begin{array}{l}\text { Sheet pile } \\
\text { wall }\end{array}$ & $\sqrt{ }$ & $\sqrt{ }$ & up to $5 \mathrm{~m}$ & $165-240$ & None & large & fair \\
\hline \multirow[b]{2}{*}{$\begin{array}{l}\text { Soldier } \\
\text { pile wall }\end{array}$} & $\sqrt{ }$ & $\sqrt{ }$ & up to $5 \mathrm{~m}$ & $160-300$ & None & medium & poor \\
\hline & $\sqrt{ }$ & $\sqrt{ }$ & $5-20 \mathrm{~m}^{(3)}$ & $165-705$ & $\begin{array}{l}0.6 \mathrm{H}+ \\
\text { anchor } \\
\text { bond } \\
\text { length }\end{array}$ & $\begin{array}{l}\text { small to } \\
\text { large }\end{array}$ & N/A \\
\hline $\begin{array}{l}\text { Slurry } \\
\text { wall }\end{array}$ & $\sqrt{ }$ & $\sqrt{ }$ & $5-25 \mathrm{~m}^{(3)}$ & $540-925$ & None ${ }^{(4)}$ & small & good \\
\hline $\begin{array}{l}\text { Tangent } \\
\text { pile wall }\end{array}$ & $\sqrt{ }$ & $\sqrt{ }$ & $\begin{array}{c}3-9 \mathrm{~m} \\
6-24 \mathrm{~m}^{(3)}\end{array}$ & $430-810$ & None ${ }^{(4)}$ & small & fair \\
\hline $\begin{array}{l}\text { Secant } \\
\text { pile wall }\end{array}$ & $\sqrt{ }$ & $\sqrt{ }$ & $\begin{array}{c}3-9 \mathrm{~m} \\
6-24 \mathrm{~m}^{(3)}\end{array}$ & $430-810$ & None ${ }^{(4)}$ & small & fair \\
\hline $\begin{array}{l}\text { Soil mixed } \\
\text { wall }\end{array}$ & $\sqrt{ }$ & $\sqrt{ }$ & $6-24 \mathrm{~m}^{(3)}$ & $435-540$ & None ${ }^{(4)}$ & small & fair \\
\hline $\begin{array}{l}\text { Soil nail } \\
\text { wall }\end{array}$ & $\sqrt{ }$ & $\sqrt{ }$ & $3-20 m$ & $165-600$ & $\begin{array}{c}0.6 \text { to } \\
1.0 \mathrm{H} \\
\end{array}$ & $\begin{array}{c}\text { medium to } \\
\text { large }\end{array}$ & N/A \\
\hline \multicolumn{8}{|c|}{$\begin{array}{l}\text { Notes: } \\
\text { (1) Total installed costs in } 1995 \text { US Dollars } \\
\text { (2) Right-of-way (ROW) requirements expressed as the distance (as a fraction of the } \\
\text { height of the wall, H) behind the wall face where fill placement is generally } \\
\text { required for flat backfill conditions, except where noted. } \\
\text { (3) Height range given for wall with anchors } \\
\text { (4) ROW required if wall includes tieback anchors }\end{array}$} \\
\hline
\end{tabular}


Table 4.3 Fill retaining device advantages and disadvantages (FHWA, 1995)

\begin{tabular}{|c|c|c|}
\hline Wall Type & Advantages & Disadvantages \\
\hline $\begin{array}{l}\text { Masonry and } \\
\text { Concrete walls }\end{array}$ & \multirow{3}{*}{$\begin{array}{ll}\text { - } & \text { durable } \\
\text { - } & \text { requires less backfill than } \\
& \text { MSE walls } \\
\text { - } & \text { concrete can meet aesthetic } \\
\text { requirements } \\
\text { - } \\
\text { well-established design and } \\
\text { performance }\end{array}$} & \multirow[t]{3}{*}{$\begin{array}{l}\text { deep foundation support may } \\
\text { be necessary }\end{array}$} \\
\hline $\begin{array}{l}\text { Cantilever } \\
\text { walls }\end{array}$ & & \\
\hline $\begin{array}{l}\text { Counterfort } \\
\text { walls }\end{array}$ & & \\
\hline Crib walls & \multirow{2}{*}{$\begin{array}{l}\text { - does not require skilled labor } \\
\text { or specialized equipment } \\
\text { - } \text { rapid construction }\end{array}$} & \multirow{2}{*}{$\begin{array}{l}\text { - difficult to make height } \\
\text { adjustments in the field }\end{array}$} \\
\hline Bin walls & & \\
\hline Gabion walls & $\begin{array}{l}\text { does not require skilled labor } \\
\text { or specialized equipment }\end{array}$ & - need adequate source of stone \\
\hline $\begin{array}{l}\text { MSE walls } \\
\text { (pre-cast } \\
\text { facing) }\end{array}$ & $\begin{array}{l}\text { does not require skilled labor } \\
\text { or specialized equipment } \\
\text { - flexibility in choice of facing }\end{array}$ & $\begin{array}{l}\text { - } \begin{array}{l}\text { - mequires use of select backfill } \\
\text { - } \\
\text { be constructed in non- } \\
\text { corrosive environment }\end{array} \\
\end{array}$ \\
\hline $\begin{array}{l}\text { MSE walls } \\
\text { (modular block } \\
\text { facing) }\end{array}$ & $\begin{array}{l}\text { - does not require skilled labor } \\
\text { or specialized equipment } \\
\text { - flexibility in choice of facing } \\
\text { - blocks are easily handled }\end{array}$ & $\begin{array}{l}\text { - } \text { requires use of select backfill } \\
\text { metallic reinforcements must } \\
\text { be constructed in non- } \\
\text { corrosive environment } \\
\text { reinforcement connection to } \\
\text { block is difficult to achieve }\end{array}$ \\
\hline $\begin{array}{l}\text { MSE walls } \\
\text { (geotextile } \\
\text { wire fencing) }\end{array}$ & $\begin{array}{l}\text { does not require skilled labor } \\
\text { or specialized equipment } \\
\text { geotextile layers improve } \\
\text { drainage } \\
\text { - } \\
\text { select backfill not always } \\
\text { necessary }\end{array}$ & $\begin{array}{l}\text { - facing may not be } \\
\text { aesthetically pleasing } \\
\text { geotextiles may be damaged } \\
\text { during construction } \\
\text { geotextiles are subject to } \\
\text { weathering damage }\end{array}$ \\
\hline
\end{tabular}


Table 4.4 Cut retaining device advantages and disadvantages (FHWA, 1995)

\begin{tabular}{|c|c|c|}
\hline Wall Type & Advantages & Disadvantages \\
\hline Sheet pile wall & $\begin{array}{ll} & \text { rapid construction } \\
\text { - } & \text { readily available } \\
\end{array}$ & $\begin{array}{l}\text { - difficult to construct in hard } \\
\text { ground }\end{array}$ \\
\hline $\begin{array}{l}\text { Soldier pile } \\
\text { wall }\end{array}$ & $\begin{array}{l}\text { - } \text { rapid construction } \\
\text { - } \text { soldier beams can be drilled } \\
\text { or driven }\end{array}$ & $\begin{array}{l}\text { difficult to maintain vertical } \\
\text { tolerances in hard ground } \\
\text { potential for ground loss at } \\
\text { excavated face }\end{array}$ \\
\hline $\begin{array}{l}\text { Anchored } \\
\text { soldier pile }\end{array}$ & $\begin{array}{l}\text { - can resist large horizontal } \\
\text { pressures } \\
\text { - adaptable to varying site } \\
\text { conditions }\end{array}$ & 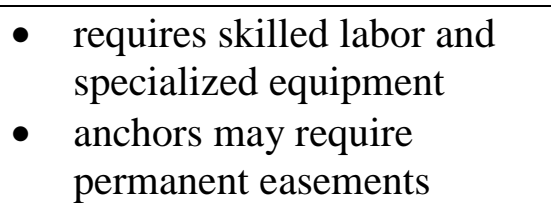 \\
\hline Slurry wall & $\begin{array}{l}\text { - } \quad \text { can be constructed in all soil } \\
\text { types or weathered rock } \\
\text { - } \quad \text { watertight } \\
\text { - } \quad \text { wide range of wall stiffness }\end{array}$ & $\begin{array}{ll}\text { - } & \text { requires specialty contractor } \\
\text { - } & \text { significant spoil for disposal } \\
\text { - } & \text { requires specialized } \\
& \text { equipment }\end{array}$ \\
\hline $\begin{array}{l}\text { Tangent pile } \\
\text { wall }\end{array}$ & - can control wall stiffness & $\begin{array}{ll}\text { - } & \text { difficult to maintain vertical } \\
\text { tolerances in hard ground } \\
\text { - } & \text { significant spoil for disposal } \\
\end{array}$ \\
\hline $\begin{array}{l}\text { Secant pile } \\
\text { wall }\end{array}$ & $\begin{array}{l}\text { - } \text { adaptable to irregular layout } \\
\text { - can control wall stiffness }\end{array}$ & $\begin{array}{ll}\text { - } & \text { requires specialized } \\
\text { equipment } \\
\text { - } & \text { significant spoil for disposal }\end{array}$ \\
\hline $\begin{array}{l}\text { Soil mixed } \\
\text { wall }\end{array}$ & $\begin{array}{ll}\text { - } & \text { constructed in all soil types } \\
\text { - } & \text { adaptable to irregular layout } \\
\text { - } & \text { relatively small spoil } \\
& \text { quantities }\end{array}$ & $\begin{array}{l}\text { - } \text { requires specialized } \\
\text { equipment } \\
\text { relatively small bending } \\
\text { capacity }\end{array}$ \\
\hline Soil nail wall & $\begin{array}{l}\text { - } \quad \text { rapid construction } \\
\text { - } \text { requires only light } \\
\text { construction equipment }\end{array}$ & $\begin{array}{l}\text { - nails require permanent } \\
\text { easements } \\
\text { - difficult to construct and } \\
\text { design below the water table } \\
\text { - } \begin{array}{l}\text { requires permanent } \\
\text { dewatering system }\end{array}\end{array}$ \\
\hline
\end{tabular}

The FHWA (1995) report uses the summary charts of the key factors of fill and cut wall systems for retaining device selection. Table 4.1 and Table 4.2 show key selection factors for fill and cut walls respectively. Both tables have columns describing the following: Perm. and Temp. columns indicate if the retaining device design life can be permanent or 
temporary, respectively; the Height Effective Cost Range column refers to the range of heights where this retaining device is cost effective; the Cost in Dollars per Square Meter of Wall are presented in 1995 US dollars; and the required ROW (right-of-way) column presents the distance affected by the construction of the wall, generally expressed as a fraction of height of the wall, $\mathrm{H}$. The lower values for the cost and required ROW represent low walls and the upper values are for high walls and walls that support sloping backfills. Table 4.1 has an additional column with the Tolerable Differential Settlement, a common performance criterion for fill wall systems. Table 4.2 has two new columns: Lateral Movements and Water Tightness. Lateral Movement provides an approximate indication of the ground surface settlements behind the wall. Table 4.3 and Table 4.4 present the advantages and disadvantages for fill and cut walls respectively. Factors that are similar for the different systems are not included in these tables; however, every retaining structure group is explained with more detail in the following sections. The types of retaining devices are grouped in the research classification groups discussed in Chapter 3: Rigid and Cantilever Gravity Walls, Flexible Gravity Walls, Mechanically Stabilized Earth Walls, Driven Walls, Cast in-place walls and Soil Nailing.

\subsubsection{Rigid and Cantilever Gravity Walls}

FHWA (1995) classifies Rigid and Cantilever Gravity Walls (RCGW) in two groups. The first group includes masonry and concrete walls. These walls are typically used for bridge abutments, and retaining walls. The unit cost of construction for this group ranges from $\$ 270$ - \$370 per square meter of wall and includes: concrete, granular soil backfill, drainage elements, labor, equipment, foundation preparation and construction of the wall 
drainage system. These walls have a cost-effective height typically between 1.0 to 3.0 meters. The base requires a width from 0.5 to 0.7 of the height of the wall. This group has the following advantages: they are conventional wall systems with well-established design and performance characteristics. Concrete, properly constructed, is very durable in many environments, and can be formed, textured and colored to meet aesthetic requirements. This type of walls is economical for heights less than 3.0 meters. They have the following disadvantages: formwork is necessary for construction; deep foundation support may be required if the wall is founded on weak soils; and cost of construction may be prohibitive if adequate source of aggregate is not available.

The second group includes cantilever and counterfort walls. These walls are typically used for bridge abutments, retaining walls, and for slope stabilization. The unit cost of construction of these devices range from $\$ 270$ - $\$ 650$ per square meter of wall and includes: concrete, steel reinforcement, granular soil backfill, drainage elements, labor, equipment, foundation preparation and construction of the wall drainage system. Cantilever walls have a cost-effective height typically between 2.0 to 9.0 meters and counterfort walls a cost-effective height typically between 9.0 to 18.0 meters. The base requires a width from 0.4 to 0.7 of the height of the wall. This group has the following advantages: they are conventional wall systems with well-established design and performance characteristics; concrete, properly constructed, is very durable in many environments and can be formed, textured and colored to meet aesthetic requirements. Counterfort walls undergo less lateral displacement than cantilever walls. They have the following disadvantages: formwork is necessary for construction; deep foundation support may be required if the wall is founded on weak soils; L-shaped cantilever walls 
may be required in areas with strict right-of-way requirements, and additional costs are associated with formwork, labor and construction of counterforts.

\subsubsection{Flexible Gravity Walls}

FHWA (1995) classifies Flexible Gravity Walls (FGW) in three groups: Crib; Bin; and Gabion walls.

Crib walls are typically used as retaining walls, and for slope stabilization. The unit cost of construction ranges from $\$ 270$ - $\$ 380$ per square meter of wall and includes: pre-cast concrete or timber elements, granular soil backfill, drainage elements, labor, equipment, foundation preparation, and construction of the wall and drainage system. These walls have a cost-effective height typically between 2.0 to 11.0 meters. The base requires a width from 0.5 to 0.7 of the height of the wall. This group has the following advantages: the construction is rapid and does not require specialized labor or equipment; the wall elements are relatively small in size; and the construction of the wall system does not require heavy equipment. They have the following disadvantages: the on-site changes and wall height adjustments are difficult to make for some systems since components are produced off-site; limited space within cribs requires use of hand compaction equipment; the face can be climbed on; and soil erosion can occur in the open-faced crib walls.

Bin walls are typically used as retaining walls, and for slope stabilization. The unit cost of construction of these devices range from $\$ 270$ - \$380 per square meter of wall and includes: prefabricated metal or reinforced concrete elements, granular soil backfill, drainage elements, labor, equipment, foundation preparation, and construction of wall and drainage system. These walls have a cost-effective height typically between 2.0 to 
11.0 meters. The base requires a width from 0.5 to 0.7 of the height of the wall. This group has the following advantages: the construction is rapid and does not require specialized labor or equipment; they do not require significant maintenance; and the wall face is fully enclosed to prevent loss of backfill. They have the following disadvantages: the on-site changes and wall height adjustments are difficult to make for some systems since components are produced off-site; limited space within bins requires use of hand compaction equipment; metal bins can be affected by corrosion in aggressive soils; and the system can accommodate only minor differential settlements.

Gabion walls are typically used as retaining walls, and for slope stabilization. The unit cost of construction ranges from $\$ 270$ - $\$ 540$ per square meter of wall and includes: gabion baskets, select stone, granular soil backfill, drainage elements, labor, equipment, foundation preparation, and construction of the wall and drainage system. These walls have a cost-effective height typically between 2.0 to 8.0 meters. The base requires a width from 0.5 to 0.7 of the height of the wall. This group has the following advantages: the wall system is extremely flexible and can undergo relatively large settlements without distress; and the appearance is suitable for rural areas. They have the following disadvantages: the source of stone must be available nearby for the wall to be economical; the gabion baskets are subject to corrosion in aggressive soils; and the wall system requires significant maintenance. 


\subsubsection{Mechanically Stabilized Earth Walls}

FHWA (1995) classifies Mechanically Stabilized Earth (MSE) walls in: (1) Segmental, pre-cast facing MSE walls; (2) Prefabricated modular block facing MSE walls; and (3) Geotextile/Geogrid/Welded facing MSE walls.

Segmental, pre-cast facing MSE walls are typically used in bridge abutments, retaining walls, and slope stabilization. They are also used in seawalls, dams and storage bunkers. The unit cost of construction of these devices range from $\$ 240$ - $\$ 380$ per square meter of wall and includes: facing panels, reinforcements, concrete leveling pad, granular soil backfill, drainage elements, labor, equipment, foundation preparation, and construction of the wall and drainage system. These walls have a cost-effective height typically between 3.0 to 20.0 meters. The base requires a minimum reinforcement length of 0.7 of the wall height. This group has the following advantages: the construction is relatively rapid and does not require specialized labor or equipment; limited foundation preparation is required; the system is flexible and can accommodate relatively large settlements without distress; the reinforcement is light and easy to handle; and the concrete facing panels permit great flexibility for facing and architectural finishes. The disadvantages of these systems are: they require the use of select backfill to ensure the necessary stress transfer mechanism between soil and reinforcement; the use of metallic reinforcements require that the backfill meet minimum electrochemical requirements for corrosion protection; and the connections between the reinforcement and the facing are susceptible to damage due to differential settlement.

Prefabricated modular block facing MSE walls are hybrid systems. They are typically used in retaining walls, and slope stabilization. The unit cost of construction ranges from 
$\$ 175$ - \$275 per square meter of wall and includes: modular concrete blocks, reinforcements, concrete leveling pad, granular soil backfill, drainage elements, labor, equipment, foundation preparation, and construction of the wall and drainage system. These walls have a cost-effective height typically between 2.0 to 11.0 meters. The base requires a minimum reinforcement length of 0.7 of the wall height. This group has the following advantages: the construction is relatively rapid and does not require specialized labor or equipment; limited foundation preparation is required; the system is flexible and can accommodate relatively large settlements without distress; the hollow core modular blocks and the reinforcement are light and easy to handle; the modular blocks permit flexibility in choosing size, shape, weight, texture, and color; and the system can adapt to sharp curves and front batter.

Geotextile/Geogrid/Welded facing MSE walls are typically used in retaining walls, and slope stabilization. They are also used as sound and noise absorbing embankment walls. The unit cost of construction ranges from $\$ 165$ - $\$ 380$ per square meter of wall and includes: reinforcements, facing panels (if needed), granular soil backfill (if needed), drainage elements, labor, equipment, foundation preparation, and construction of the wall and drainage system. These walls have a cost-effective height typically between 2.0 to 15.0 meters. The base requires a minimum reinforcement length of 0.7 of the wall height. This group has the following advantages: the construction is relatively rapid and does not require specialized labor or equipment; limited foundation preparation is required; the system is flexible and can accommodate relatively large settlements without distress; the reinforcement is light and easy to handle; and the geotextile layers improve drainage of the backfill. The disadvantages of these systems are that: the geotextile or geogrid face is 
irregular and may not meet aesthetic requirements; geotextile and geogrid life can be reduced due to exposure to ultraviolet light; and permanent systems require use of select backfill to ensure the necessary stress transfer mechanism between soil and reinforcement.

\subsubsection{Driven Walls}

FHWA (1995) classifies Driven Walls (DW) in: Sheet pile walls; and Soldier pile walls. Sheet pile walls are typically used in retaining walls, slope stabilization, and excavation support. They are also used in marine walls and docks. The unit cost of construction ranges from $\$ 165$ - $\$ 240$ per square meter of wall and includes: the steel or concrete sheet piles, labor, equipment, and construction of the wall. These walls have a cost-effective height typically between 2.0 to 5.0 meters. This group has the advantage that the system can be used in applications penetrating below the water table. Sheet pile walls have the following disadvantages: the construction requires specialized equipment; driving sheet piles is noisy and it can induce vibrations; the interlocks between sheet piles may be lost while driving which allows water to drain into the excavation; and is difficult to drive sheets in hard or dense soils, and also in gravelly soils.

Soldier piles walls are typically used in slope stabilization, temporary excavation support, and retaining walls. The unit cost of construction ranges from $\$ 160$ - $\$ 300$ per square meter of wall and includes: the soldier piles, lagging, facing panels (if required), drainage elements, labor, equipment, and construction of the wall. These walls have a costeffective height typically between 2.0 to 5.0 meters. Soldier piles walls have the following advantages: fewer elements are driven compared to sheet pile walls; the soldier 
piles can also be drilled; and the system is cost effective. The system has the following disadvantages: the construction requires specialized equipment; driving piles is noisy and can induce vibrations; ground loss may occur at the excavated face if left unsupported; it is difficult to drive piles in hard or dense soils, and also in gravelly soils; and the vibration induced can produce settlements in loose ground.

An additional group is presented in FHWA (1995) for anchored soldier pile systems. They are typically used in bridge abutments, retaining walls, slope stabilization, and excavation support. The unit cost of construction from range $\$ 165$ - $\$ 705$ per square meter of wall and includes: soldier piles, lagging, facing panels (if required), drainage elements, tieback anchors, grout, labor, equipment, construction of the wall and installation, proof testing and stressing of tieback anchors. These walls have a costeffective height typically between 5.0 to 20.0 meters. Anchored soldier pile walls have the following advantages: unobstructed working space can be achieved inside the excavation; can resist large horizontal earth pressures; and proof testing tieback anchors assure quality. The following disadvantages are innate to the system: the construction requires skilled labor and specialized equipment; underground easement may be required for tiebacks and anchor zone; tiebacks space is limited by underground structures or utilities; and the anchor capacity may be difficult to achieve in cohesive soils.

\subsubsection{Cast in-place walls}

Cast in-place walls (CIPW) are classified into three groups by FHWA (1995): Slurry Walls; Tangent and Secant Pile Walls; and Soil Mix Walls. 
Slurry walls are typically used in retaining walls, slope stabilization, and excavation support. They are also used in cut and cover tunnels and buildings foundations. The unit cost of construction ranges from $\$ 540$ - $\$ 925$ per square meter of wall and includes: the bentonite slurry, concrete and steel reinforcement or pre-cast concrete panels, facing panels (if required), tieback anchors, labor, equipment, and construction of the wall. These walls have a cost-effective height typically between 6.0 to 24.0 meters with tieback anchors and a width between 0.4 to 1.0 meters. This group has the following advantages: it is watertight; lateral movements are relatively small; suitable for construction in all soil types; unobstructed working space can be achieved on-site; and the construction does not produce significant noise or vibrations. The disadvantages are: the construction requires a specialty contractor; it is difficult to obtain a smooth finished face; and the system is relative expensive.

Tangent and Secant Pile walls are used in retaining walls and excavation support. The unit cost of construction ranges from $\$ 430$ - \$810 per square meter of wall and includes: concrete, steel reinforcement, facing panels, tieback anchors (if required), labor, equipment, and construction of the wall. These walls without anchors have a costeffective height typically between 3.0 to 9.0 meters and 6.0 to 24.0 meters with anchors. The pile diameters are typically between 0.5 to 1.0 meter. The advantages of this system include: lateral movements are relatively small; and adaptability to irregular installation arrangements. These walls have the following disadvantages: construction requires specialty contractor and equipment; and a watertight tangent pile wall is difficult to construct due to small gaps between the piles. 
Soil Mix walls are typically used in retaining walls and excavation support. The unit cost of construction ranges from $\$ 435$ - $\$ 540$ per square meter of wall and includes: the cement slurry or other hardening agent, steel reinforcement, facing panels (if required), tieback anchors, labor, equipment, and construction of the wall. These walls have a costeffective height typically between 6.0 to 24.0 meters with anchors. The pile diameter is typically 1.0 meter. This group has the following advantages: little excavation spoil is produced; and adaptability to irregular installation arrangements. The system has the following disadvantages: specialty contractor and equipment are required for construction; and soil-cement surface when exposed to freeze-thaw cycles may form layers that flake away from the surface.

\subsubsection{Soil Nailing}

Soil nailing is typically used in retaining walls, slope stabilization, and excavation support. They are also used for tunnel facing support and widening under existing bridges. The unit cost of construction ranges from $\$ 165$ - $\$ 600$ per square meter of wall and includes: shotcrete, facing panels (if required), drainage elements, soil nails, grout, labor, equipment, construction of the wall and drainage system, and installation and field testing of the nails. These walls have a cost-effective height typically between 3.0 to 20.0 meters. The soil nail length ranges from 0.6 to 1.0 times the height of the wall. Advantages for this system include: cost-effectiveness, only light construction and grouting equipment are necessary; the surface movements can be limited by installing additional nails or by pre-stressing the nails in the upper level to a small percentage of the working loads; adaptable to site conditions since only small diameter drilling is 
performed; and they are well suited for construction in areas of limited headroom. Disadvantages include: the nails require an underground easement to protect the soil-nail interaction; drainage systems are difficult to construct, and control of ground water is limited; closely spaced nails may interfere with utilities; nail capacity may be difficult to develop in cohesive soils; and the face with shotcrete alone may not meet aesthetic requirements.

\subsubsection{Wall Selection}

The FHWA (1995) recommended process of selection starts by identifying the need for a retaining device. The following step is to identify the site constrains and project requirements. Once all this information is recognized the tables presented are used to evaluate the different systems. Geometry, construction, performance, aesthetics, and environmental factors are considered in the charts to decide from all possible solutions to few alternatives. The final selection is based on an analysis of the remaining alternatives. Calculations for the final dimensions and design, estimates of performance, time of construction and cost are performed for each remaining system. The retaining device that better complies with all the factors becomes the final selection.

\subsection{Electronic Database Comparison}

In Chapter 3 it has been established the necessity for the development of a retaining device case history database. This database is used to develop technical guidelines for the use of retaining devices. In order to develop these guidelines the factors gathered in the 
database are analyzed, and the case stories compared with each other though a number of queries.

The analysis has been performed taking into account the Indiana Department of Transportation Specifications and three separate issues from our database: (1) geotechnical; (2) experience and performance of the wall; and (3) cost issues. Geotechnical issues consider the type of the retaining device, the geometry of the wall, and the soil conditions. Experience and performance deal with the issues of service, construction, and durability of the device.

\subsubsection{Indiana Department of Transportation specifications}

The Indiana Department of Transportation produces design specifications for the letting of their projects, including provisions for retaining devices. Most of the specifications frequently used are found in the Standard Specifications Book (INDOT, 2001). Other specifications also used are included in the Recurring Special Provisions. These specifications directly influence the practice of Retaining Devices in the State.

INDOT Standard Specifications Section 714 refers to concrete retaining walls. The specification requires that the fill material for retaining structures shall be B Borrow. The specifications for this material can be found in Section 211 of the Standard Specifications. The material consists of suitable sand, gravel, crushed stone, air cooled blast furnace slag, granulated blast furnace slag, or other approved material. This material is also specified by INDOT for all structural fills. The B Borrow, following Section 203.23, is compacted to at least $95 \%$ of the maximum dry density and within -2 and +1 
percentage points of the optimum moisture content, obtained using compaction methods according to Section 203.24 and AASHTO T 99.

The specifications on the Recurring Special Provisions relating to retaining devices are: 625-R-194 for Gabions, 714-R-003 for Bin Walls, and 731-R-202 for MSE walls.

The gabions' specifications include provisions for the materials, wire mesh, mesh openings, and pullout resistance.

The specifications for MSE walls, Section 731, include the following provisions: the maximum allowable yield stress of the reinforcement, $450 \mathrm{MPa}$; the maximum standard panel size, $3 \mathrm{~m}^{2}$; the minimum length of reinforcement, at least $2.5 \mathrm{~m}$ or $0.7 \mathrm{H}$ (height of the wall); more provisions exist on reinforcements and connections spacing. It is also specified that for design the backfill soil should be taken to have 34 degrees of internal friction angle and 30 degrees for the fill behind the MSE wall.

The specifications presented in this section are for the retaining devices usually used by INDOT for the letting of their projects. Other specifications may be used for particular projects but they are not standardized. These specifications influence the current practice in the State of Indiana and have to be considered in the project.

\subsubsection{Geotechnical Issues}

To analyze the influence of the geotechnical issues in the selection of retaining structures, correlations of the soil conditions with the wall type, status (i.e. whether it failed or not) and height are established. The height of the retaining devices reflects cost-effective construction of walls. However some bias exists in the literature because only large or difficult projects are typically reported. Walls with a status of "failed" reflect walls below 
the lower limit of serviceability. For analysis, a series of queries are created in our database. The goal of these queries is to correlate the type of the wall with the maximum height, and with the soil condition as foundation or as backfill.

Four queries, ":Results Analysis :CHRI :BF/SS", “:Results Analysis :CHRI :Foundation", “:Results Analysis :CHRL :BF/SS" and ":Results Analysis :CHRL :Foundation", first create a summary of the tables Case History Review: Literature (CHRL) and Case History Review: Indiana (CHRI). A Microsoft Access (MSA) macro, a series of recorded systematic steps, is created to run the four queries and create the table, "Results Analysis" (RA). The macro name is "Create Height Analysis Report". The table RA should be created every time the information needs to be analyzed. After RA is created, the cross-tab query ":Results Analysis CHR" is used to correlate the data and present a summary. The report ":Results Analysis CHR" made from the cross-tab query has been divided into two tables: one for fill walls, Table 4.5; and one for cut walls, Table 4.6. Both tables present the average height of the retaining devices in the database as a function of: type of retaining device, as described in Chapter 2 (column 1); No Cases, in column 2, shows the number of case histories from the database in each category; Support Type (i.e. if additional support is needed for stability) in column 3; Status in column 4 shows if the wall is in service or failed (Research indicates a structure constructed for research); and finally Soil, the remaining columns, describes the type of soil either located behind the wall (BF/SS in column 5) or the soil in the foundation (Found. in column 5).

A total of fourteen cases of Rigid and Cantilever Gravity Walls (RCGW) exist in the database. None of the walls needed additional support. Ten of these cases failed; they had 
an average height of 11.9 meters, eight of them did not have a coarse soil backfill and seven of them had foundation in fine soil. The cases in service have an average height of 3.0 meters, all of them had coarse soil backfill and no information was available about the foundation soil. Two of the cases are cantilever walls and the third is a masonry wall. There is a RCGW case used for research; it is a Counterfort wall with a height of 6.5 meters. The heights of the walls that failed are above the recommended heights by the FHWA (Table 4.1), the rest of the RCGW comply with the FHWA recommendations. The foundations of the failed walls were on fine-grained soil, which suggest that large differential settlements could have occurred; note that the FHWA also recommends that differential settlements should be avoided in these walls. Also, most of the failed walls do not comply with the backfill material, B Borrow, recommended by INDOT

A total of five cases of Flexible Gravity Walls (FGW) exist in the database. None of the walls needed additional support. One of the cases failed; it had a height of 8.1 meters, with a fine-grained soil backfill and a fine soil foundation. There are four cases in service with an average height of 3.7 meters, one of them have a foundation on fine soil, and all of them have a coarse soil backfill. The heights of all FGW are within the range recommended by FHWA (Table 4.1). A foundation in fine soil does not necessarily lead to failure since FGW can withstand differential settlements, which confirms the FHWA report. The wall that failed does not comply with the backfill material, B Borrow, recommended by INDOT. 
Table 4.5 Average Height of Database Fill retaining devices

\begin{tabular}{|c|c|c|c|c|c|c|c|c|c|c|c|c|c|c|c|c|c|c|c|c|}
\hline \multirow[b]{2}{*}{ 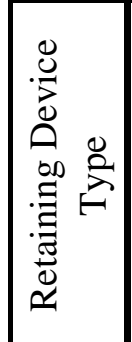 } & \multirow[b]{2}{*}{ 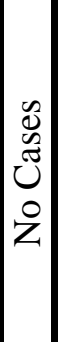 } & \multirow[b]{2}{*}{ 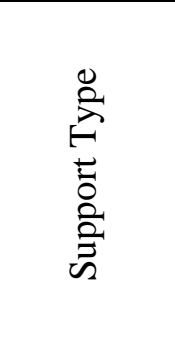 } & \multirow[b]{2}{*}{ 营 } & \multirow[b]{2}{*}{$\overline{\bar{\sigma}}$} & \multicolumn{16}{|c|}{ Average Height (m) } \\
\hline & & & & & $\begin{array}{l}\frac{n}{7} \\
\tilde{\infty} \\
\overline{1}\end{array}$ & $\begin{array}{l}0 \\
0 \\
0 \\
0 \\
1 \\
\ddot{0} \\
0 \\
0 \\
0 \\
0\end{array}$ & 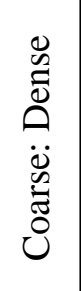 & 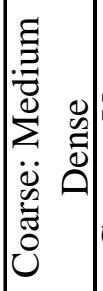 & 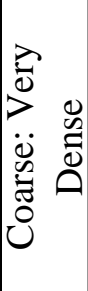 & $\begin{array}{l}\varangle \\
z \\
\ddot{d} \\
\tilde{\Xi} \\
\dot{0}\end{array}$ & 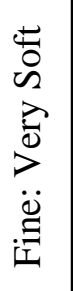 & $\begin{array}{l}\stackrel{ \pm}{0} \\
\ddot{\sim} \\
\ddot{0} \\
\dot{\Xi}\end{array}$ & 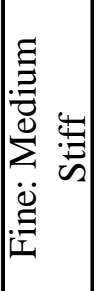 & 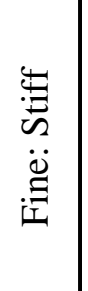 & 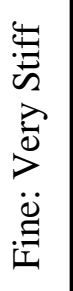 & 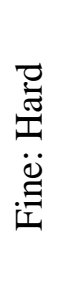 & $\begin{array}{l}\overleftarrow{\measuredangle} \\
\ddot{z} \\
\stackrel{\Xi}{\Xi}\end{array}$ & $\frac{\dot{0}}{\tilde{0}}$ & $\begin{array}{l}\text { Uै } \\
\stackrel{0}{2}\end{array}$ & $\overleftrightarrow{\measuredangle}$ \\
\hline \multirow{6}{*}{ 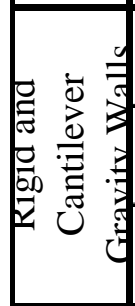 } & \multirow{2}{*}{10} & \multirow{2}{*}{$\begin{array}{l}\text { No Add. } \\
\text { Support }\end{array}$} & \multirow{2}{*}{ Failed } & $\mathrm{BF} / \mathrm{SS}$ & \multirow{2}{*}{11.9} & & & & & 10.7 & & & & 10.3 & & & 14.8 & 12.2 & & 14.5 \\
\hline & & & & Found. & & & & & & 12.2 & & & & 10.3 & & & 13.5 & & 10.7 & 14.5 \\
\hline & \multirow{2}{*}{3} & \multirow{2}{*}{$\begin{array}{l}\text { No Add. } \\
\text { Support }\end{array}$} & \multirow{2}{*}{$\begin{array}{c}\text { In Service } \\
\text { / Served } \\
\end{array}$} & $\mathrm{BF} / \mathrm{SS}$ & \multirow{2}{*}{3.0} & & 3.6 & & & 2.7 & & & & & & & & & & \\
\hline & & & & Found. & & & & & & & & & & & & & & & & 3.0 \\
\hline & \multirow[b]{2}{*}{1} & \multirow{2}{*}{$\begin{array}{l}\text { No Add. } \\
\text { Support }\end{array}$} & \multirow{2}{*}{ Research } & $\mathrm{BF} / \mathrm{SS}$ & \multirow{2}{*}{6.5} & & 6.5 & & & & & & & & & & & & & \\
\hline & & & & Found. & & & 6.5 & & & & & & & & & & & & & \\
\hline \multirow{4}{*}{ 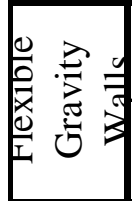 } & \multirow{2}{*}{1} & \multirow{2}{*}{$\begin{array}{l}\text { No Add. } \\
\text { Support }\end{array}$} & \multirow{2}{*}{ Failed } & $\mathrm{BF} / \mathrm{SS}$ & \multirow{2}{*}{8.1} & & & & & & & 8.1 & & & & & & & & \\
\hline & & & & Found. & & & & & & & & & & & 8.1 & & & & & \\
\hline & \multirow{2}{*}{4} & \multirow{2}{*}{$\begin{array}{l}\text { No Add. } \\
\text { Support }\end{array}$} & \multirow{2}{*}{$\begin{array}{c}\text { In Service } \\
\text { / Served }\end{array}$} & $\mathrm{BF} / \mathrm{SS}$ & 37 & & 3.4 & & & 3.4 & & & & & & & & & 4.6 & \\
\hline & & & & Found. & 3.1 & & & & & & & & 3.4 & & & & & & & 3.8 \\
\hline & 3 & No Add. & Failed & $\mathrm{BF} / \mathrm{SS}$ & 03 & & & & & & & & & & & & 10.0 & & & 8.0 \\
\hline$:=$ & 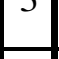 & Support & ramed & Found. & 9.5 & & & & & & & & & & & & & & & 9.3 \\
\hline ज्ञ $\triangleq$ & 46 & No Add. & In Service & $\mathrm{BF} / \mathrm{SS}$ & 60 & & 4.3 & 5.8 & 8.3 & 8.5 & & & & & & & 3.2 & & & 5.9 \\
\hline $23^{n}$ & 40 & Support & / Served & Found. & 0.9 & 9.4 & 13.7 & 7.8 & & & & 6.0 & & & 7.5 & & 3.1 & 8.4 & & 5.9 \\
\hline 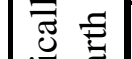 & 9 & No Add. & Research & $\mathrm{BF} / \mathrm{SS}$ & 57 & & 4.6 & & 6.1 & 4.0 & & & & & & & 6.0 & & & \\
\hline 馬 & & Support & & Found. & $J .1$ & & & 6.1 & & & & & & & & & 4.3 & & & 6.0 \\
\hline ల్ & 1 & Soil Impr. & In Service & $\mathrm{BF} / \mathrm{SS}$ & 48 & & 4.8 & & & & & & & & & & & & & \\
\hline & $|1|$ & and other & / Served & Found. & 4.8 & & & & & & 4.8 & & & & & & & & & \\
\hline & 2 & No Add. & Research & $\mathrm{BF} / \mathrm{SS}$ & 6.4 & & & & 6.4 & & & & & & & & & & & \\
\hline 过 & 2 & Support & Kesearcn & Found. & 0.4 & & & 6.4 & & & & & & & & & & & & \\
\hline 空离 & 10 & Soil & In Service & $\mathrm{BF} / \mathrm{SS}$ & 8.2 & & & & & & & & & & & & 8.2 & & & \\
\hline & 1 & Improv. & / Served & Found. & 8.2 & & & & & & 8.2 & & & & & & & & & \\
\hline
\end{tabular}


Table 4.6 Average Height of Database Cut retaining devices

\begin{tabular}{|c|c|c|c|c|c|c|c|c|c|c|c|c|c|c|c|c|c|c|c|c|}
\hline \multirow[b]{2}{*}{ 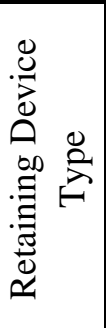 } & \multirow[b]{2}{*}{$\begin{array}{l}\tilde{U} \\
\tilde{z} \\
\tilde{\tilde{u}} \\
\tilde{z} \\
0 \\
z\end{array}$} & \multirow[b]{2}{*}{ 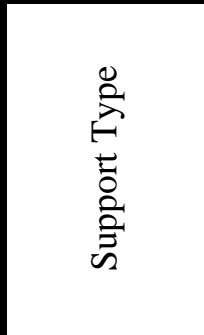 } & \multirow[b]{2}{*}{ 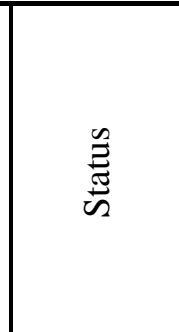 } & \multirow[b]{2}{*}{$\overline{\bar{\delta}}$} & \multicolumn{16}{|c|}{ Average Height $(\mathrm{m})$} \\
\hline & & & & & $\begin{array}{l}\stackrel{n}{0} \\
\stackrel{0}{0} \\
\bar{Z}\end{array}$ & 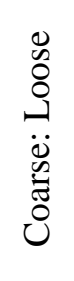 & 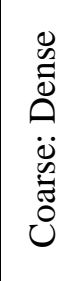 & 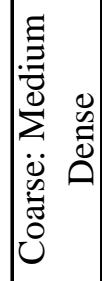 & 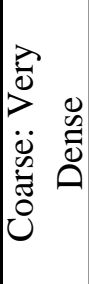 & 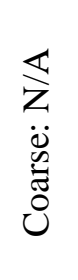 & 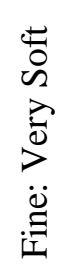 & $\begin{array}{l}\stackrel{\varpi}{0} \\
\ddot{n} \\
\ddot{\ddot{\theta}} \\
\stackrel{\Xi}{I}\end{array}$ & 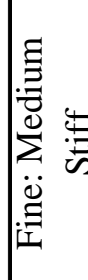 & $\begin{array}{l}\stackrel{\Xi}{\Xi} \\
\ddot{\oplus} \\
\ddot{\Xi}\end{array}$ & 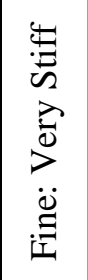 & $\begin{array}{l}\overrightarrow{0} \\
\underset{\Xi}{\Xi} \\
\ddot{\Xi} \\
\ddot{I}\end{array}$ & $\begin{array}{l}\underset{Z}{\mathbb{Z}} \\
\underset{0}{\dot{\Xi}}\end{array}$ & $\begin{array}{l}\bar{\Xi} \\
\stackrel{ \pm}{0}\end{array}$ & $\begin{array}{l}\frac{y}{0} \\
0 \\
2\end{array}$ & $\frac{\mathbb{z}}{\mathrm{z}}$ \\
\hline \multirow{16}{*}{ 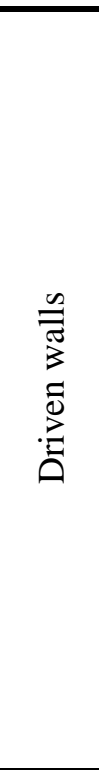 } & \multirow{2}{*}{1} & \multirow[t]{2}{*}{ Braced } & \multirow{2}{*}{$\begin{array}{c}\text { In Service } \\
\text { / Served }\end{array}$} & \multirow{2}{*}{\begin{tabular}{|l|}
$\mathrm{BF} / \mathrm{SS}$ \\
Found. \\
\end{tabular}} & \multirow{2}{*}{7.8} & & & & & & & 7.8 & & & & & & & & \\
\hline & & & & & & & & & & & & 7.8 & & & & & & & & \\
\hline & \multirow{2}{*}{3} & \multirow{2}{*}{$\begin{array}{l}\text { No Add. } \\
\text { Support }\end{array}$} & \multirow{2}{*}{$\begin{array}{c}\text { In Service } \\
\text { / Served }\end{array}$} & $\mathrm{BF} / \mathrm{SS}$ & \multirow{2}{*}{1.8} & 2.0 & & & & 2.1 & & & & & & & & & & 1.2 \\
\hline & & & & Found. & & & & 2.1 & & & & & & & 2.0 & & & & & 1.2 \\
\hline & \multirow{2}{*}{1} & \multirow[t]{2}{*}{ Other } & \multirow{2}{*}{$\begin{array}{c}\text { In Service } \\
\text { / Served } \\
\end{array}$} & $\mathrm{BF} / \mathrm{SS}$ & \multirow{2}{*}{1.5} & & & & & & & & & & & & & & & 1.5 \\
\hline & & & & Found. & & & & & & & & & & & & & & & & 1.5 \\
\hline & \multirow{2}{*}{1} & \multirow{2}{*}{$\begin{array}{c}\text { Soil } \\
\text { Improv. and }\end{array}$} & \multirow{2}{*}{$\begin{array}{c}\text { In Service } \\
\text { / Served }\end{array}$} & $\mathrm{BF} / \mathrm{SS}$ & \multirow{2}{*}{19.5} & & & & & & & & 19.5 & & & & & & & \\
\hline & & & & Found. & & & & & & & & & & & & & & & 19.5 & \\
\hline & \multirow{2}{*}{1} & Soil & \multirow{2}{*}{$\begin{array}{c}\text { In Service } \\
\text { / Served }\end{array}$} & $\mathrm{BF} / \mathrm{SS}$ & \multirow{2}{*}{7.6} & 7.6 & & & & & & & & & & & & & & \\
\hline & & Improv. and & & Found. & & & 7.6 & & & & & & & & & & & & & \\
\hline & 1 & Soil Nailing & In Service & $\mathrm{BF} / \mathrm{SS}$ & & & & & & & & & & & & & & & & \\
\hline & 1 & & / Served & Found. & N/A & & & & & & & & & & & & & & & \\
\hline & 1 & Tieback & & $\mathrm{BF} / \mathrm{SS}$ & & & & & & & & & & & & & & & & \\
\hline & 1 & & Fa1led & Found. & N/A & & & & & & & & & & & & & & & \\
\hline & 18 & Tieback & In Service & $\mathrm{BF} / \mathrm{SS}$ & 97 & & 11.8 & 11.9 & 17.0 & 9.9 & & & 7.9 & & 7.6 & & 2.1 & & & 6.3 \\
\hline & $\mid 18$ & & / Served & Found. & 9.1 & & 5.8 & 10.6 & 11.4 & & & 10.3 & 9.2 & 5.0 & 11.7 & & & & 16.1 & 6.3 \\
\hline & 5 & Braced & In Service & $\mathrm{BF} / \mathrm{SS}$ & 0131 & & & & 20.0 & & & & 12.0 & & 11.0 & & 10.7 & & & \\
\hline & 3 & & / Served & Found. & $j^{15.1}$ & & & 14.7 & 20.0 & & & & & 9.3 & 11.0 & & & & & 10.7 \\
\hline$\stackrel{2}{1}=$ & 1 & No Add. & In Service & $\mathrm{BF} / \mathrm{SS}$ & 72 & & & & & & & & & & 7.2 & & & & & \\
\hline$=3$ & 1 & Support & / Served & Found. & 1.2 & & & & & & & & & & & 7.2 & & & & \\
\hline & 1 & Other & In Service & $\mathrm{BF} / \mathrm{SS}$ & 300 & & & & & & & & & & & & 30.0 & & & \\
\hline & 1 & & / Served & Found. & 1 & & & & & & & & & & & & & & 30.0 & \\
\hline
\end{tabular}


Table 4.6 Average Height of Database Cut retaining devices (Cont'd)

\begin{tabular}{|c|c|c|c|c|c|c|c|c|c|c|c|c|c|c|c|c|c|c|c|c|}
\hline \multirow[b]{2}{*}{ 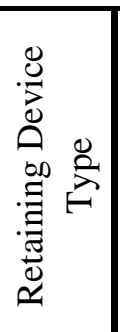 } & \multirow[b]{2}{*}{$\begin{array}{l}\tilde{d} \\
\tilde{z} \\
\tilde{u} \\
0 \\
z\end{array}$} & \multirow[b]{2}{*}{ 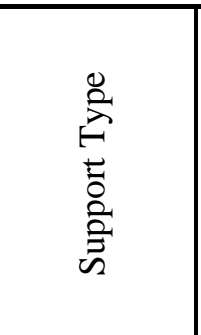 } & \multirow[b]{2}{*}{ 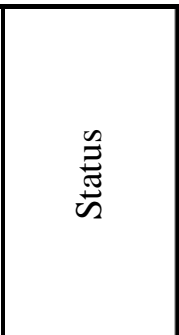 } & \multirow[b]{2}{*}{$\overline{0}$} & \multicolumn{16}{|c|}{ Average Height (m) } \\
\hline & & & & & $\begin{array}{l}\infty \\
\tilde{0} \\
\tilde{\infty} \\
\bar{z}\end{array}$ & 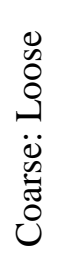 & 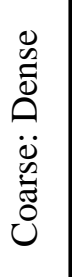 & 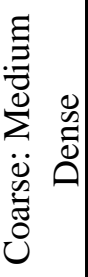 & 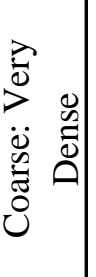 & 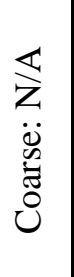 & 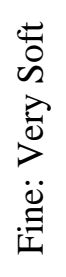 & 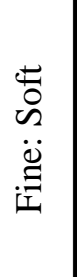 & 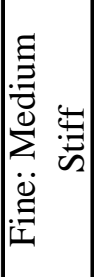 & 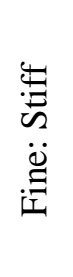 & 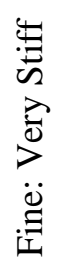 & 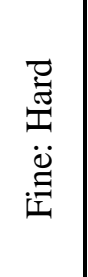 & 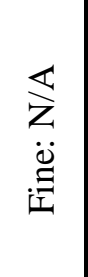 & $\frac{\bar{\Xi}}{\stackrel{ \pm}{0}}$ & $\begin{array}{l}\frac{y}{0} \\
0\end{array}$ & 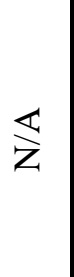 \\
\hline \multirow{6}{*}{ 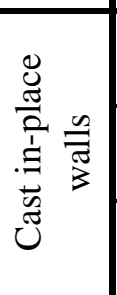 } & \multirow{2}{*}{3} & \multirow{2}{*}{$\begin{array}{l}\text { Soil Impr. } \\
\text { and Braced }\end{array}$} & \multirow{2}{*}{\begin{tabular}{|c|} 
In Service \\
/ Served
\end{tabular}} & \multirow{2}{*}{\begin{tabular}{|l|} 
BF/SS \\
Found. \\
\end{tabular}} & \multirow{2}{*}{13.3} & & & & & & & 7.8 & & & & & 16.0 & & & \\
\hline & & & & & & & & & & & & 7.8 & & & & & 17.0 & & 15.0 & \\
\hline & \multirow{2}{*}{1} & \multirow{2}{*}{$\begin{array}{c}\text { Soil Impr. } \\
\text { and Tieback }\end{array}$} & \multirow{2}{*}{$\begin{array}{c}\text { In Service } \\
\text { / Served }\end{array}$} & \multirow{2}{*}{\begin{tabular}{|l|} 
BF/SS \\
Found. \\
\end{tabular}} & \multirow{2}{*}{19.4} & & & & & & & & 19.4 & & & & & & & \\
\hline & & & & & & & & & & & & & 19.4 & & & & & & & \\
\hline & \multirow{2}{*}{3} & \multirow[t]{2}{*}{ Tieback } & \multirow{2}{*}{\begin{tabular}{|c|} 
In Service \\
/ Served
\end{tabular}} & \multirow{2}{*}{$\begin{array}{l}\text { BF/SS } \\
\text { Found. }\end{array}$} & \multirow{2}{*}{11.8} & & 8.0 & & & & & & & & & 19.8 & 7.6 & & & \\
\hline & & & & & & & & & & & & & & & & & & 7.6 & 13.9 & \\
\hline \multirow{4}{*}{ 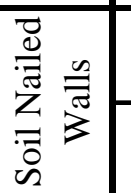 } & \multirow{2}{*}{7} & \multirow{2}{*}{$\begin{array}{l}\text { No Add. } \\
\text { Support }\end{array}$} & \multirow{2}{*}{\begin{tabular}{|c|} 
In Service \\
/ Served
\end{tabular}} & $\mathrm{BF} / \mathrm{SS}$ & \multirow{2}{*}{10.2} & & & 3.9 & 14.7 & & & & 14.5 & & & & & & & 5.0 \\
\hline & & & & Found. & & & 3.9 & & 13.7 & & & & & & & & & & 15.5 & 5.0 \\
\hline & \multirow{2}{*}{2} & \multirow{2}{*}{$\begin{array}{l}\text { No Add. } \\
\text { Support }\end{array}$} & \multirow{2}{*}{ Research } & $\mathrm{BF} / \mathrm{SS}$ & \multirow{2}{*}{5.3} & & & 7.0 & & & & & & 3.5 & & & & & & \\
\hline & & & & Found. & & & & & & 7.0 & & & & & & & & 3.5 & & \\
\hline
\end{tabular}


A total of fifty-nine cases of Mechanically Stabilized Earth (MSE) walls are available in the database. One of the MSE walls needed additional support; a cantilever wall was used as facing; the soil in the foundation was improved to reduce settlements; the wall has a height of 4.8 meters. Three of the MSE cases failed, they had an average height of 9.3 meters, two of them had fine soil backfill, but no information was available for their foundation. The average height of the MSE cases in service without additional support is 6.9 meters, two of the cases had fine soil backfill and six had a foundation in fine soil. Nine MSE walls were constructed for research purposes, with an average height of 5.7 meters; two of the walls had fine soil as backfill and two had foundations in fine soil. The heights of all MSE walls are within the range recommended by FHWA (Table 4.1). A foundation and backfill of fine soil does not lead to failure, which confirms the FHWA report. Although several walls that used fine soil as backfill did not fail, INDOT recommends the use of B Borrow as backfill. The failure of the three MSE walls was related to the backfill material and is explained in the following section. Hybrid systems (HS) are considered MSE walls by the FHWA. Three HS are available in the database, and none of them failed. One had additional support to reduce the settlements in a very soft fine soil and had a height of 8.2 meters, which is within the FHWA recommended range.

A total of twenty-seven Driven Walls (DW) are available in the database. Only three DW did not have additional support, and had an average height of 1.8 meters. Most of the remaining DW had heights over five meters, except two. One case had "other" type of additional support (an unusual sheet pile arrangement) and had a height of 1.5 meters. The other case is a dead man anchored sheet pile wall in a waterfront, with a height of 2.1 
meters. Tiebacks are used in various soil conditions and there is only one case of bracing, which is insufficient to develop a trend. All unsupported DW are smaller than five meters as recommended by the FHWA (Table 4.2); most of the supported DW are taller than five meters, with the exception of two cases, as explained.

A total of fourteen cases of Cast In-Place Walls (CIPW) exist in the database. Only one CIPW, with a height of 7.2 meters, does not have additional support. Most of the remaining CIPW have heights over ten meters, except two that are around seven meters. CIPW walls are used in various soil conditions, however they seem to be more common in fine soils in our database. The unsupported CIPW is a pile wall and is in the recommended range by the FHWA (Table 4.2), between 3.0 and 9.0 meters. The supported CIPW are in the range of 6.0 - 24.0 meters, as recommended by FHWA, except a 30 meter tall CIPW that is supported by a inner beam ring system.

A total of nine soil nail walls are available in the database. None of them either required additional support or failed. Two of them have a fine soil behind the wall (one case was for research). The average height of the walls in service is 10.2 meters. All soil nail walls are within the range recommended by the FHWA (Table 4.2), between 3.0 - 20 meters.

\subsubsection{Experience and Performance Issues}

The report "CHRL: Experience \& Performance" presents the experience summaries of the cases stored in the database. From the experience of each case the following conclusions are drawn for the different retaining devices.

(1) Most of the failures of Rigid and Cantilever Walls (RCGW) were caused by changes of the water table in the backfill. Another reason for failure was long-term deterioration 
of the cohesive backfill. A proper drainage system should be designed and cohesive backfill should be avoided. INDOT specifications require the use of B borrow for structural backfill, therefore reducing the risk of failure of the RCGW. Soft foundation soils should be avoided which is one of the disadvantages mentioned in the FHWA recommendations for this type of wall (Table 4.3).

(2) The Flexible Gravity Walls (FGW) failure was caused by effects of freezing and thawing in a cohesive backfill, which led to a long-term progressive failure.

(3) It has been reported that the galvanized metal elements of a bin wall did not suffer any significant corrosion after 40 years of service. FGW cases with foundations on soft soils indicate that differential settlement is not a concern for this type of wall, which is in agreement with FHWA recommendations.

(4) The three Mechanically Stabilized Earth (MSE) walls that failed had cohesive backfill. However, the factor that led to failure was the raise of the groundwater table due to a substantial rainfall. Problems with compaction of the backfill, especially around the connection of the reinforcement of MSE walls, are commonly reported. No significant corrosion of metallic MSE reinforcement has been reported. Many of the MSE walls have cohesive soils in the foundation, which indicates that large differential settlements can be easily accommodated; however, special considerations should be made to avoid damage to the facing elements. Proprietary systems are constantly developed to achieve a better connection system and to control the deformations on the facing elements. Soil improvement was used in two cases to prevent settlements due to special needs of the projects (e.g. one of the projects was a railroad embankment). 
(5) A large number of Driven Walls (DW) is used, which indicates that there is a great deal of confidence in this system. One of the concerns of this system is the settlement that can occur during construction, especially if the time between excavation and placement of the lagging is large. DW with anchors for deep cuts are widely used in many soil types. Soil improvement was used as additional support for two DW cases to give additional stability to the foundation and to be used as a cut off wall. The failure of the anchored DW was related to a poor design and inadequate construction, and does not reflect the characteristics of the system. This case was mitigated with the use of soil nails, which were used because there was limited headroom for other equipment.

(6) A bias for braced Cast In-Place Walls (CIPW) in fine soils is observed in our data. This bias occurs because most of the cases reported for CIPW are deep excavations in cohesive soil for buildings in densely constructed areas, where bracing is temporary until the building slabs are finished. CIPW are selected in most of the cases because its capacity to produce small settlements in fine soils, which agrees with the recommendations from the FHWA report (see Table 4.2). This device is typically either braced or anchored; an exception has been found in the literature where no additional support was used because the bracing length would have been too large, and tiebacks were not permitted in the area.

(7) For Soil nail walls the lack of experience with its design and construction seems to be the basic limitation for its use. There is also concern about the corrosion of the steel nails for permanent walls. Their real limitation is that in clean sand, immediately after the soil's frictional resistance does not provide excavation sufficient stability to the unreinforced section of the wall. 
(8) Overall the most reported problem in our database is the lack of a comprehensive geotechnical study for the design of the wall.

\subsubsection{Cost issues}

The information regarding cost is scarce since it is not common to report costs in the technical literature. Contractors and INDOT project lettings are the basic source for this information. Table 4.7 shows the average prices from the Table of Case History Review: INDOT's Database (CHRID). In Table 4.7 the information is correlated with the type of wall. Each bidding item is accompanied by its corresponding description. The next column of the table presents the average price per unit measurement (length, area, or lump sum) of the wall. The prices are given in dollars from lettings of the past five years, and it is not normalized for inflation. The unit prices presented are similar to the unit prices given in INDOT (2001), which correspond to a period from June 1998 to July 1999. Table 4.8 shows a summary of the unit prices found for the different types of retaining structures, taking into account all the cost information gathered in the electronic database, including the costs in Table 4.7. The table also presents a comparison with the values recommended by FHWA (1995).

Table 4.8 shows that the average unit prices of FGW and MSE walls from the database are in the range of the FHWA and close to the average. In the database RCGW, DW, and Soil nail walls have a cost on the upper bracket of the FHWA, and CIPW appear to be cheaper than the FHWA recommended cost. The differences may be due to bias in our database (i.e. the cases considered could be more expensive than national average due to unusual construction difficulties), or due to inherent differences between geotechnical 
conditions in the Sate of Indiana with respect to national average, or simply due to a small number of representative cases in our database.

Table 4.7 Unit prices obtained from INDOT's Letting data

\begin{tabular}{|c|c|c|c|c|}
\hline Type & ITEM & Description & $\begin{array}{l}\text { Average } \\
\text { unit price }\end{array}$ & Unit \\
\hline $\begin{array}{l}\text { Rigid and Cantilever } \\
\text { Gravity Walls }\end{array}$ & 714-93016 & Wall, stone & 511.11 & $\mathrm{~m}^{2}$ \\
\hline \multirow{2}{*}{ Flexible Gravity Walls } & 714-02402 & $\begin{array}{l}\text { Retaining wall, bin type, } 2 \text {, } \\
\text { design A }\end{array}$ & 280.78 & $\mathrm{~m}^{2}$ \\
\hline & 714-02403 & $\begin{array}{l}\text { Retaining wall, bin type, } 2 \text {, } \\
\text { design B }\end{array}$ & 326.20 & $\mathrm{~m}^{2}$ \\
\hline \multirow{8}{*}{$\begin{array}{l}\text { Mechanically Stabilized } \\
\text { Earth Walls }\end{array}$} & 714-02102 & $\begin{array}{l}\text { Retaining wall, modular, } \\
\text { concrete }\end{array}$ & 201.88 & $\mathrm{~m}^{2}$ \\
\hline & 714-04802 & $\begin{array}{l}\text { Concrete modular block } \\
\text { wall }\end{array}$ & 214.07 & $\mathrm{~m}^{2}$ \\
\hline & $714-93263$ & Wall panel materials & 172.67 & $\mathrm{~m}^{2}$ \\
\hline & $714-93264$ & Wall panel erection & 74.74 & $\mathrm{~m}^{2}$ \\
\hline & $714-95163$ & $\begin{array}{l}\text { Retaining wall, internally } \\
\text { reinforced ea }\end{array}$ & 394.66 & $\mathrm{~m}^{2}$ \\
\hline & $731-93945$ & Face panels, concrete & 151.69 & $\mathrm{~m}^{2}$ \\
\hline & $731-93946$ & Wall erection & 110.25 & $\mathrm{~m}^{2}$ \\
\hline & $731-93947$ & Leveling pad, concrete & 78.30 & $\mathrm{~m}$ \\
\hline Driven Walls w/ anchors & $714-99072$ & Tieback wall & 288150.00 & LS \\
\hline Soil Nailed Walls & $731-06223$ & Soil nailed wall & 669.27 & $\mathrm{~m}^{2}$ \\
\hline
\end{tabular}

Table 4.8 Estimated unit prices per meter square of wall based on complete database

\begin{tabular}{|l|c|c|}
\hline \multirow{2}{*}{ Type of retaining device } & \multicolumn{2}{|c|}{ Estimated Unit Price per $\mathbf{~ m}^{2}$ of wall } \\
\cline { 2 - 3 } & CHR Average & FHWA Range \\
\hline RCGW (Concrete and Masonry walls) & $\$ 370$ & $\$ 270-\$ 370$ \\
\hline FGW (Crib and Bill walls) & $\$ 300$ & $\$ 270-\$ 380$ \\
\hline MSE walls (pre-cast facing) & $\$ 280$ & $\$ 240-\$ 380$ \\
\hline MSE walls (modular block facing) & $\$ 210$ & $\$ 165-\$ 380$ \\
\hline DW with anchors & $\$ 885$ & $\$ 165-\$ 705$ \\
\hline CIPW with anchors & $\$ 440$ & $\$ 540-\$ 925$ \\
\hline Soil nail walls & $\$ 670$ & $\$ 165-\$ 600$ \\
\hline
\end{tabular}


Nevertheless, it is seen that MSE walls are the cheapest fill walls and that generally anchored walls are very expensive. Therefore since the DW are the most common walls used without anchors, they are the cheapest for cut projects.

\subsection{Retaining Device Selection Guidelines}

A number of factors have been analyzed in the previous sections; namely FHWA recommendations, INDOT specifications, geotechnical, experience and performance, and cost factors. These factors enable us to develop a series of logical steps for the selection of the type of a retaining device. The following considerations have been used in the development of the guidelines:

Rigid and Cantilever Gravity Walls (RCGW) cannot tolerate much differential settlement, and require a right-of-way of about 0.7 times the height of the wall. RCGW can be grouped into Concrete and Masonry walls, and Cantilever and Counterfort walls. Concrete and Masonry walls are cost-effective for heights less than 3.0 meters. Cantilever walls are cost-effective from 2.0 to 9.0 meters height and counterfort walls are costeffective from 9.0 to 18.0 meters. Cantilever and counterfort walls are the most expensive solution for fill retaining devices but can have a pleasant appearance.

Flexible Gravity Walls (FGW) can tolerate some differential settlement, require a rightof-way of about 0.7 times the height of the wall, and have an effective cost range from 2.0 to 11.0 meters height. FGW can be grouped into Gabion Walls, and Crib and Bin walls. Gabion walls can tolerate more differential settlements than Crib and Bin walls. 
Mechanically Stabilized Earth (MSE) Walls can tolerate differential settlement and are the least expensive of the fill retaining devices. However, these walls require a right-ofway of more than 0.7 times the height of the wall.

Driven Walls (DW) have a cost effective range of up to 5.0 meters height and are the least expensive of the cut retaining devices when they are not anchored. If water tightness is needed sheet piles walls should be used. All cut walls that have anchors increase their cost substantially and require a right-of-way of approximately 0.6 times the height of the wall plus the anchor bond length. Anchored Driven Walls have a cost effective range from 5.0 to 20.0 meters of height. Driven Walls can produce small to large lateral movements and are difficult to drive in hard ground.

Cast In-Place Walls (CIPW) have a cost effective range from 6.0 to 24.0 meters height, are the most expensive choice for cut retaining devices, they produce small lateral movements, and can be watertight. When anchored they require a right-of-way of approximately 0.6 times the height of the wall plus the anchor bond length.

Soil nail walls have a cost effective range of 3.0 to 20.0 meters height, they produce medium to large lateral movements and require a right-of-way from 0.6 to 1.0 times the height of the wall. However in cohesionless sand, the frictional resistance of the soil is not sufficient to provide stability to the unreinforced section of the wall immediately after excavation.

These conclusions are organized in the form of flowcharts for the selection of the retaining devices. Figure 4.1 and Figure 4.2 show two flowcharts for the selection of retaining devices for fills and cuts, respectively. 


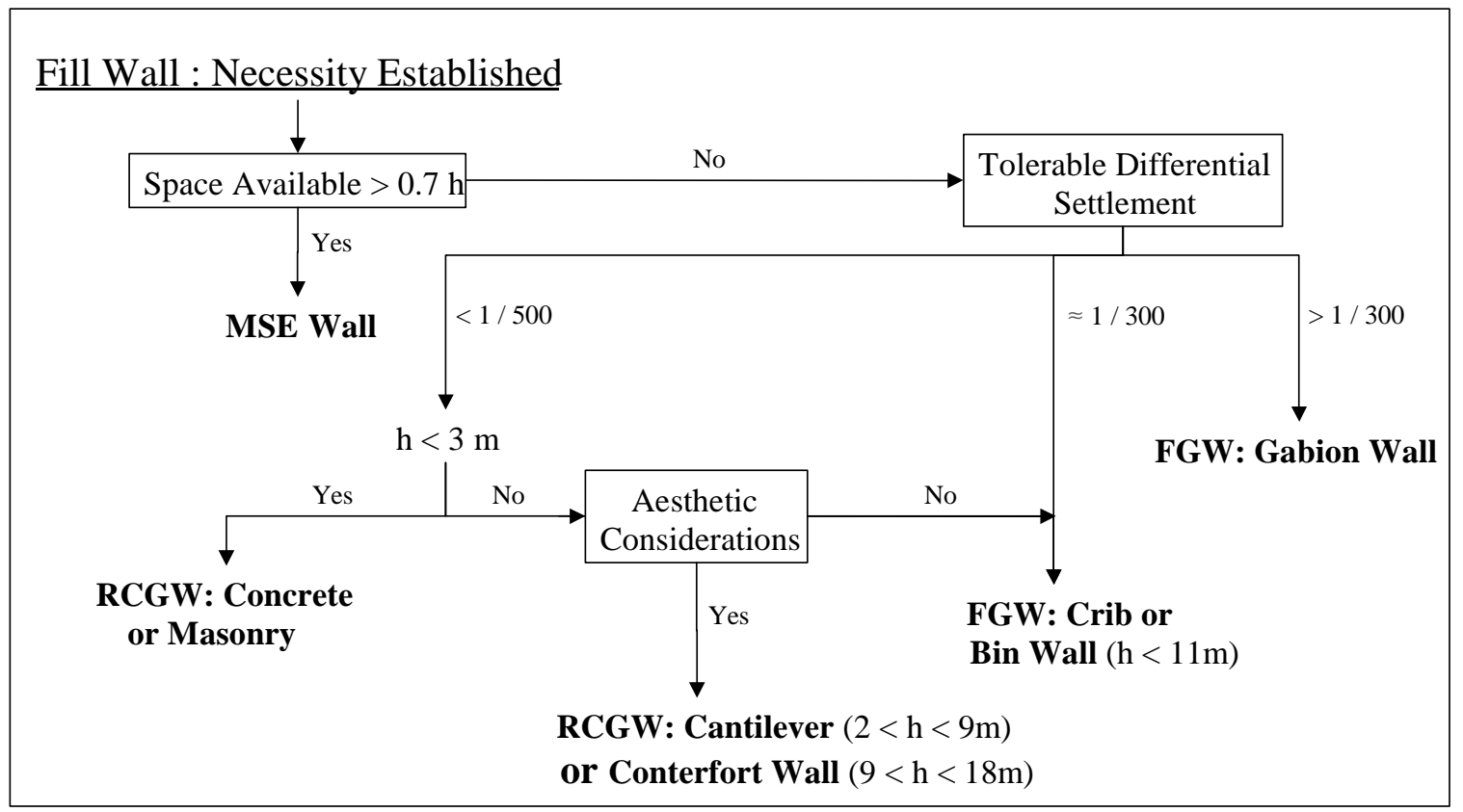

Figure 4.1 Fill wall selection flowchart

The flowchart in Figure 4.1 starts with the need for a retaining fill device. The next consideration is the space available behind the wall, or right-of-way (ROW). If the space available is greater than 0.7 times the height of the wall (h) economy indicates that the use of Mechanically Stabilized Earth (MSE) wall is recommended. If less space is available the device should be either a Rigid and Cantilever Gravity Wall (RCGW) or a Flexible Gravity Wall (FGW). The differential settlement of the wall is used for the next selection step. If the expected differential settlement is larger than $1 / 300$ the device should be a FGW: Gabion wall. If the expected differential settlement is less than 1/500 and the height is less than 3.0 meters, the most economic solution is a RCGW: Masonry or Concrete; for heights larger than 3.0 meters, and aesthetic considerations are critical the device should be a RCGW: Cantilever (for walls between 2 - 9 meters) and a RCGW: Counterfort (for walls between 9 - 18 meters). If less strict aesthetics considerations are 
used, the differential settlement expected is between $1 / 300$ and $1 / 500$, and the height is less than $11 \mathrm{~m}$ a FGW: Bin or Crib wall is recommended. If no option is obtained, the best solution is an MSE wall and the space required behind the wall should be made available.

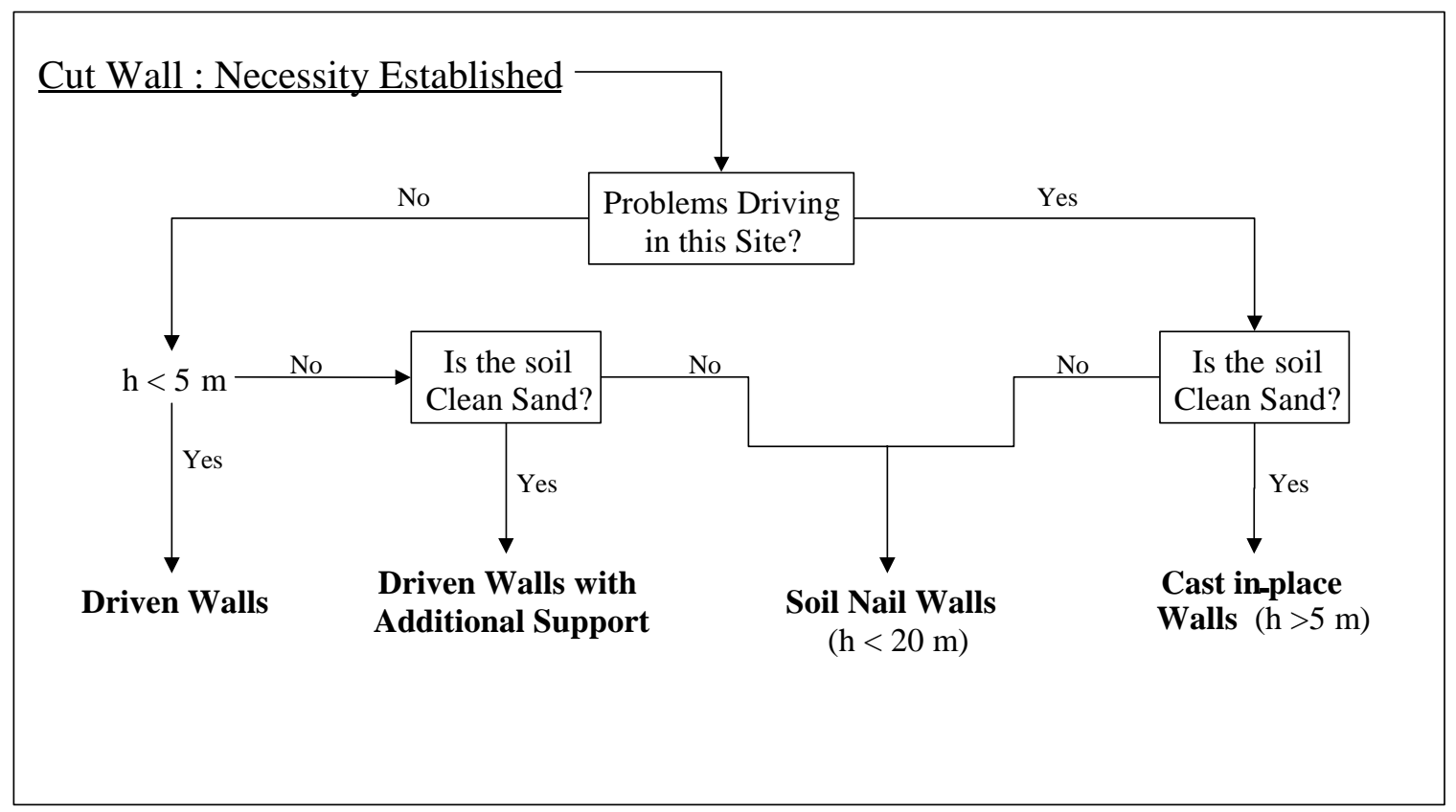

Figure 4.2 Cut wall selection flowchart

The flowchart in Figure 4.2 starts with the need for a cut-retaining device. If soil or environmental factors do not prevent pile driving and the required height is less than 5.0 meters the choice is a Driven Wall without anchors. Unless watertight, aesthetics, or deformation control conditions are needed, the choice between: pre-cast concrete, sheet piles, soldier piles, and bored-in-place wall depends on the cost of construction and materials. If the wall is higher than 5.0 meters and the soil is a clean sand a Driven Wall with anchors is selected; classification between a cast in-situ and a soil-cement wall also depends on costs. If driving is not possible and the soil is a clean sand, a Cast In-Place 
Wall (CIPW) with anchors should be used. However, CIPW with heights lower than five meters are not cost effective. Finally, if the soil is not a clean sand and one of the following two conditions occur: (1) the wall is higher than five meters, or (2) driving is not possible, the most economic solution is a soil nail wall. However, this wall is not cost effective for heights larger than 20 meters. If no option is obtained, the best solution should be based on a cost analysis of the walls. In addition to the flowchart, if concern for soil movement behind the wall exists the CIPW give the most effective control for ground settlements.

\section{4 $\underline{\text { Conclusions }}$}

To develop guidelines for the selection of retaining devices, the database of the project, the FHWA recommendations and INDOT specifications have been analyzed. The analysis of the database has been performed taking into account three separate issues: (1) geotechnical, (2) experience and performance, and (3) cost.

From the study of the geotechnical issues of the database cases the following conclusions have been drawn:

(1) Mechanically Stabilized Earth (MSE) Walls can tolerate large differential settlement; Flexible Gravity Walls (FGW) can tolerate up to 1/50; and. Rigid and Cantilever Gravity Walls (RCGW) can only tolerate up to $1 / 500$.

(2) The use of a fine-grained backfill without pore pressure considerations typically leads to failure of fill retaining devices.

(3) Driven Walls (DW) and Cast in-place walls (CIPW) above five meters require additional support systems. 
(4) Soil Nail walls are not used in soils without sufficient frictional resistance to provide stability to the un-reinforced section of the wall immediately after excavation.

(5) CIPW provide the best control of settlements among the cut retaining devices.

(6) The optimum, most cost-effective, type of wall selection strongly depends on the height of the wall and on the soil conditions.

From the study of the experience and performance issues of the database cases the following conclusions have been drawn:

(1) Freezing and thawing in a cohesive backfill leads to long-term progressive failure of fill retaining devices.

(2) Corrosion of galvanized metallic elements is usually insignificant.

(3) Compaction of the backfill around the connection of the reinforcement of MSE walls is usually a reported as problematic in the database.

(4) Although MSE walls can tolerate differential settlement, special considerations should be made to avoid damage to the facing elements due to the wall deformations.

(5) Additional settlement can occur in DW during construction if the time between excavation and placement of the lagging is large.

(6) Soil nails have had a limited use because of the lack of experience with its design and construction.

(7) The most reported problem in our database is the lack of a comprehensive geotechnical study for the design of walls.

From the study of the cost issues of the database cases the following conclusions have been drawn: 
(1) MSE walls are the cheapest fill retaining devices and DW are the cheapest cut retaining devices.

(2) If MSE cannot be used, Concrete and Masonry walls (a type of RCGW) are the most cost effective devices for heights smaller than three meters. Higher RCGW are more expensive, which makes FGW a better option.

(3) Additional support for DW and CIPW higher than five meters is expensive, which makes Soil nail walls more cost effective. CIPW are typically the most expensive option. Through this analysis two flowcharts for selection of retaining devices have been developed, one for fill and one for cut devices. The following main factors have been used to construct the flowcharts:

(1) For fill retaining devices: Right of way, differential settlement, aesthetics and costs.

(2) For cut retaining devices: Construction, cost and soil type.

The guidelines created satisfy both the recommendations issued by the Federal Highway Administration (FHWA) and the Indiana Department of Transportation (INDOT).

The correct characterization of the subsurface conditions with an adequate site exploration is vital for the selection and design of a retaining structure. A missed feature will influence the factors used for the selection and may cause failure of the device. Once the need of a retaining device is established and the site and geotechnical investigations are performed the appropriate flowchart can be used. Based on geometry and soil conditions the choices for retaining devices can be reduced to a couple of alternatives. These alternatives can then be designed in detail and cost estimations can be made. The final choice is based on cost and design feasibility along with better fulfillment of the project requirements. 


\section{CHAPTER V. CONCLUSIONS AND RECOMMENDATIONS}

This chapter is divided in two sections: (1) Conclusions; and (2) Recommendations. In the first section a summary of the work done is presented as well as the major findings of the research. In the second section recommendations for implementation of the findings are proposed.

\section{1 $\underline{\text { Conclusions }}$}

An extensive literature review has been conducted to investigate the types of retaining devices most used in the United States and in the State of Indiana. The goal of the project is to provide the Indiana Department of Transportation with guidelines to select the type of retaining device most appropriate for a given project, given the geotechnical considerations at the site.

A new classification of retaining devices has been developed where the walls are divided into fill and cut walls. Fill walls support a backfill while cut walls support the natural ground. Fill walls are subdivided in: (1) Rigid and Cantilever Gravity Walls (RCGW); (2) Flexible Gravity Walls (FGW); and (3) Mechanically Stabilized Earth (MSE) Walls. Cut walls are subdivided in: (1) Driven Walls (DW); (2) Cast in-place Walls (CIPW); and (3) Soil Nailed Walls (SNW). 
Databases storing a large number of case histories can be used as decision tools for design. Furthermore, the information stored can be utilized for: (1) development of correlations and trends among the cases in the database; (2) comparison of a new wall design with the case histories in the database to determine similarities and differences between the new and existing projects.

An electronic database with 207 selected cases from the technical literature and from INDOT archives has been created. The database has been generated with the program Microsoft Access, which has been selected because it is easy to use, readily available, and it can be easily upgraded. The cases are grouped as follows: (1) Case History Review: Literature, that contains case histories from all over the world; (2) Case History Review: INDOT Database, that contains cases of walls build in Indiana and includes the construction cost; and (3) Case History Review: Indiana, that contains cases from INDOT database and from a survey of local contractors and engineers. The database stores the following information: (1) Type of Retaining Device, location; (2) Geometry: Dimensions (height, length, etc.); (3) Soil conditions: Foundation, backfill; (4) Experience and Performance (Service: Deformations during and after construction); (5) Construction: Material used, construction process, problems; (6) Durability: Maintenance records, type and cost; (7) Economy: Construction and maintenance costs; (8) Other issues: special considerations, noise levels, etc. 
The information in the database is searchable, and has been analyzed through a number of correlations. The following conclusions are obtained:

(1) The most cost-effective type of wall for a given project depends on the height of the wall and on the soil conditions.

(2) For fill walls:

(a) Mechanically Stabilized Earth (MSE) Walls can tolerate large differential settlements; Flexible Gravity Walls (FGW) can tolerate differential settlements up to 1/50; and Rigid and Cantilever Gravity Walls (RCGW) can only tolerate differential settlements up to $1 / 500$.

(b) The use of a fine-grained backfill without pore pressure considerations typically leads to failure of the wall. Freezing and thawing also leads to long-term progressive failure in a cohesive backfill.

(c) Corrosion of galvanized metallic elements is usually not significant.

(d) Compaction of the backfill around the connection of the reinforcement of MSE walls is usually reported as a problem.

(e) Large differential settlements in MSE walls can cause damage to the facing elements.

(f) MSE walls are the most economic fill retaining devices. If MSE walls cannot be used, Concrete and Masonry walls are the most cost effective devices for heights smaller than three meters. For larger heights, FGW are typically used.

(g) A flowchart has been developed to identify the most cost-effective solution based on the height of the wall, cost, and soil conditions. 
(3) For cut walls:

(a) Driven Walls (DW) and Cast in-place walls (CIPW) above five meters require additional support systems.

(b) Additional settlement can occur in DW during construction if the time between excavation and placement of the lagging is too large.

(c) CIPW limit the ground settlements behind the wall.

(d) Soil nails have had a limited use because of lack of experience with their design and construction. They are not used in soils without sufficient frictional resistance, which is necessary to provide stability to the un-reinforced section of the wall immediately after excavation.

(e) DW are the cheapest cut retaining devices. Additional support for DW and CIPW higher than five meters is expensive, which makes Soil Nail walls more cost effective. CIPW are generally the most expensive option.

(f) A flowchart has been developed to identify the most cost-effective solutions based on the height of the wall, cost, and soil conditions.

(4) The most often reported problem in the database is the lack of a comprehensive geotechnical study.

(5) The conclusions obtained are in agreement with recommendations from the Federal Highway Administration (FHWA), and with specifications from the Indiana Department of Transportation. 


\section{2 $\underline{\text { Recommendations }}$}

The following recommendations are made:

(1) Use the flowcharts developed as a preliminary decision-making tool to decide the optimum type of wall for a given project.

(2) The flowcharts and additional notes provide general recommendations based on limited information. The flowcharts are not intended to cover all possible cases; they should be used for preliminary design and to facilitate engineering decision. Sitespecific conditions or project constraints may require a different solution than that provided by the charts.

(3) The recommendations are based on up-to-date information. It is expected that with time design trends and wall typologies may become obsolete and new technologies may become available. It is recommended that the database and flowcharts be updated every five years. 
BIBLIOGRAPHY 


\section{BIBLIOGRAPHY}

T. M. Allen; B. R. Christopher; R. D: Holtz, Performance of a 12.6m high geotextile wall in Seattle, Washington, Geosynthetic-Reinforced Soil Retaining Walls, Rotterdam; Brookfield: A.A. Balkema, 1992, 81-100

Daniel Alzamora; Mark H. Wayne; Jie Han, Performance of SRW Supported by Geogrids and Jet Grout Columns, Performance confirmation of constructed geotechnical facilities: proceedings of sessions of ASCE Specialty Conference on Performance Confirmation of Constructed Geotechnical Facilities: April 9-12, 2000, Amherst, Massachusetts / sponsored by the Geo-Institute of the American Society of Civil Engineers; edited by Alan J. Lutenegger, Don J. DeGroot, Reston, Va., Geo-Institute, ASCE, c2000, 457-466

American Concrete Institute, ACI Standard - Building Code Requirements for Reinforced Concrete, ACI 318-89, Detroit, USA, 1989

American Institute of Steel Construction (AISC), Load \& resistance factor design: manual of steel construction, American Institute of Steel Construction, 2nd Edition, v1-2, USA, 1994

American Society of Civil Engineers (ASCE), Committee on Earth Retaining Structures, Guidelines of engineering practice for braced and tied-back excavations / by the Committee on Earth Retaining Structures of the Geo-Institute of the American Society of Civil Engineers, Reston, Va.: American Society of Civil Engineers, 1997

Thomas C. Anderson, Anchored Deep Soil Mixed Cutoff/Retaining Walls for Lake Parkway Project in Milwaukee, WI, Design and construction of earth retaining systems: proceedings of sessions of Geo-Congress 98, October 18-21, 1998, Boston, Massachusetts / sponsored by the Earth Retaining Structures Committee of the GeoInstitute of the American Society of Civil Engineers; edited by Richard J. Finno ... [et al.], Reston, Va.: American Society of Civil Engineers, c1998, 1-13

Lawrence A. Balanko, Norbert Morgenstern, Rudy Yacyshyn, Tangent Pile Wall, Edmonton Convention Center, Application of walls to landslide control problems: proceedings of two sessions / sponsored by the Committee on Earth Retaining Structures of the Geotechnical Engineering Division of the American Society of Civil Engineers at the ASCE National Convention, Las Vegas, Nevada, April 29, 1982; R.B. Reeves, editor, New York, N.Y.: ASCE, c1982, 108-123 
R. J. Bathurst; R. E. Crowe, Recent case histories of flexible geocell retaining walls in North America, Recent case histories of permanent geosynthetic-reinforced soil retaining walls / edited by Fumio Tatsuoka, Dov Leshchinsky, Rotterdam; Brookfield, VT: A.A. Balkema, c1994, 3-19

R. J. Bathurst; R. E. Crowe; A. Alston, Design and Construction of a Road Embankment using Geosynthetics, 42nd Canadian Geotechnical Conference, Winnipeg, Manitoba, October 1989, 266-271

P. L. Bourdeau, P. J. Fox, D. J. Runser, J. Lee, Development of low cost retaining walls for Indiana highways, Joint Transportation Research Program, Indiana Department of Transportation, Purdue University, FHWA/IN/JRTP-2001/3, 2001

David Cacoilo, George Tamaro and Peter Edinger, Design and Performance of a TiedBack Sheet Pile Wall in Soft Clay, Design and construction of earth retaining systems: proceedings of sessions of Geo-Congress 98, October 18-21, 1998, Boston, Massachusetts / sponsored by the Earth Retaining Structures Committee of the GeoInstitute of the American Society of Civil Engineers; edited by Richard J. Finno ... [et al.], Reston, Va.: American Society of Civil Engineers, c1998, 14-25

David R. Chapman, Design \& Construction of the Liberty Street Bridge Earth Support

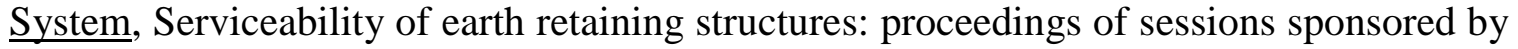
the Geotechnical Engineering Division of the American Society of Civil Engineers in conjunction with the ASCE National Convention in Atlanta, Georgia, October 9-13, 1994 / edited by Richard J. Finno, New York, N.Y.: ASCE, c1994, 112-129

Bill Chappell, Designers/Contractors Email Survey, City of Indianapolis

Y. Chen, Practical analysis and design of mechanically stabilized earth walls - I. Design philosophies and procedures, Engineering structures 22, Elsevier Science Ltd., 2000, 793-808

Y. Chen, Practical analysis and design of mechanically stabilized earth walls - II. Design comparisons and impact of LRFD method, Engineering structures 22, Elsevier Science Ltd., 2000, 809-830

R. Cheney, Selection of Retaining Structures: The Owner's Perspective, Design and performance of earth retaining structures: proceedings of a conference / sponsored by the Geotechnical Engineering Division of the American Society of Civil Engineers in cooperation with the Ithaca Section, ASCE, Cornell University, Ithaca, New York, June 18-21, 1990; edited by Philip C. Lambe and Lawrence A. Hansen, New York, N.Y.: ASCE, 1990, 52-66 
Suan S. Cheng and Lawrence A. Hansen, Design, Construction and Performance of a Soil Nailed Wall in Puerto Rico, Serviceability of earth retaining structures: proceedings of sessions sponsored by the Geotechnical Engineering Division of the American Society of Civil Engineers in conjunction with the ASCE National Convention in Atlanta, Georgia, October 9-13, 1994 / edited by Richard J. Finno, New York, N.Y.: ASCE, c1994, 1-16

Barry R. Christopher; Cynthia Bonczkiewicz; Robert D. Holtz, Design, construction and monitoring of full scale test of reinforced soil walls and slopes, Recent case histories of permanent geosynthetic-reinforced soil retaining walls / edited by Fumio Tatsuoka, Dov Leshchinsky, Rotterdam; Brookfield, VT: A.A. Balkema, c1994, 45-60

Civil Engineering codes of practice joint committee, Appendix E. Examples of failures of earth retaining structures, Earth retaining structures; [prepared by a committee convened by the institution of structural engineers], Institution of Structural Engineers, 1952, 136149

B. G. Clarke; C. P. Wroth, Analysis of Dunton Green retaining wall based on results of pressuremeter tests, Propped and cantilevered rigid walls, London: Telford, 1986, 57-69

James G. Collin; Donald G. Bright; Ryan R. Berg, Performance Summary of the Tanque Verde Project-Geogrid Reinforced Soil Retaining Walls, Serviceability of earth retaining structures: proceedings of sessions sponsored by the Geotechnical Engineering Division of the American Society of Civil Engineers in conjunction with the ASCE National Convention in Atlanta, Georgia, October 9-13, 1994 / edited by Richard J. Finno, New York, N.Y.: ASCE, c1994, 43-56

J. G. Collin; R. R. Berg, Permanent geogrid reinforced soil retaining walls - US Experience, Recent case histories of permanent geosynthetic-reinforced soil retaining walls / edited by Fumio Tatsuoka, Dov Leshchinsky, Rotterdam; Brookfield, VT: A.A. Balkema, c1994, 61-67

B. M. Das, Principles of Foundation Engineering, PWS Publishing, Pacific Grove, California, Fourth Edition, 1999

Matthew J. Crane, Designers/Contractors Email Survey, Paul I. Cripe, Inc.

Y. Doi; S. Mizushima; M. Tateyama; O. Murata, Geotextile-reinforced soil retaining wall: Reconstruction of a railway embankment at Rokujizo, Kyoto, Recent case histories of permanent geosynthetic-reinforced soil retaining walls / edited by Fumio Tatsuoka, Dov Leshchinsky, Rotterdam; Brookfield, VT: A.A. Balkema, c1994, 197-204

Elizabeth M. Dwyre, Designers/Contractors Email Survey, Professional Service Industries, Inc., Project references: I5949, I4218 9513, I7182, and I7420 
K. D. Eigenbrod; J. P. Burak, Field Measurement of Anchor Loads, Ground Temperatures and Pore Water Pressures Behind Retaining Structures in Northern Ontario, 42nd Canadian Geotechnical Conference, Winnipeg, Manitoba, October 1989, 296-303

Federal Highway Administration, First Draft Geotechnical Engineering Circular No. 1 Earth Retaining Systems FHWA Contract DTFH61-94-C00099, U.S. Department of Transportation, Federal Highway Administration prepared by P. J. Sabatini, V. Elias, G. R. Schmertmann, and R. Bonaparte, Project Number GE3686-B, 1995

Federal Highway Administration, Manual for design and construction monitoring of soil nail walls, U.S. Department of Transportation, Federal Highway Administration; [Springfield, VA: Available to the public from the National Technical Information Service], 1998

Vinod K. Garcia; Edward I. Carey; Robert W. Milne, The Cathedral Square Substation anchored excavation, Vancouver, British Columbia, Canadian Geotechnical Journal Vol. 21. 1984. Revue Canadienne de Géotechnique Vol. 21. 1984, Ottawa, National Research Council Canada, 621-633

C. Garrett; S. J. Barnes, The design and performance of the Dunton Green retaining wall, Propped and cantilevered rigid walls, London: Telford, 1986, 41-56

J. Gould, Earth Retaining Structures - Developments Through 1970, Design and performance of earth retaining structures: proceedings of a conference / sponsored by the Geotechnical Engineering Division of the American Society of Civil Engineers in cooperation with the Ithaca Section, ASCE, Cornell University, Ithaca, New York, June 18-21, 1990; edited by Philip C. Lambe and Lawrence A. Hansen, New York, N.Y.: ASCE, 1990, 8-21

J. P. Gourc; Y. Matichard, Development of geotextile reinforcement techniques in France - Application to retaining structures, Geosynthetic-Reinforced Soil Retaining Walls, Rotterdam; Brookfield: A.A. Balkema, 1992, 132-148

J. P. Gourc; Y. Matichard, Two decades of geosynthetic-reinforced structures in France, Recent case histories of permanent geosynthetic-reinforced soil retaining walls / edited by Fumio Tatsuoka, Dov Leshchinsky, Rotterdam; Brookfield, VT: A.A. Balkema, c1994, 77-98

James Harmston; Garry W. Rhodes, Soil Nailing Saves Distressed Timber Wall, Serviceability of earth retaining structures: proceedings of sessions sponsored by the Geotechnical Engineering Division of the American Society of Civil Engineers in conjunction with the ASCE National Convention in Atlanta, Georgia, October 9-13, 1994 / edited by Richard J. Finno, New York, N.Y.: ASCE, c1994, 130-136 
John Hovland and Donald F. Willoughby, Slide Stabilization at the Geysers Power Plant, Application of walls to landslide control problems: proceedings of two sessions / sponsored by the Committee on Earth Retaining Structures of the Geotechnical Engineering Division of the American Society of Civil Engineers at the ASCE National Convention, Las Vegas, Nevada, April 29, 1982; R.B. Reeves, editor, New York, N.Y.: ASCE, c1982, 77-92

Ching-Chuan Huang, Report on three unsuccessful reinforced walls, Recent case histories of permanent geosynthetic-reinforced soil retaining walls / edited by Fumio Tatsuoka, Dov Leshchinsky, Rotterdam; Brookfield, VT: A.A. Balkema, c1994, 219-221

H. W. Hubbard; D. M. Potts; D. Miller; J. B. Burland, Design of the retaining walls for the M25 cut and cover tunnel at Bell Common, Propped and cantilevered rigid walls, London: Telford, 1986, 3-20

R. E. Hunt, Geotechnical engineering analysis and evaluation, New York: McGraw-Hill, 1986

Steven W. Hunt; Randy Frank; Paul Tarvin; James Blazek, Racine's Water Street Retaining Wall, Serviceability of earth retaining structures: proceedings of sessions sponsored by the Geotechnical Engineering Division of the American Society of Civil Engineers in conjunction with the ASCE National Convention in Atlanta, Georgia, October 9-13, 1994 / edited by Richard J. Finno, New York, N.Y.: ASCE, c1994, 137154

Indiana Department of Transportation, 1999 Standards Specifications Book, Standard Publications CD-ROM, Indiana Department of Transportation, 2001

Indiana Department of Transportation, Recurring Special Provisions, Standard Publications CD-ROM, Indiana Department of Transportation, 2001

I. Juran, G. Baudrand, K. Farrag, V. Elias, Design of soil nailed retaining structures, Design and performance of earth retaining structures: proceedings of a conference / sponsored by the Geotechnical Engineering Division of the American Society of Civil Engineers in cooperation with the Ithaca Section, ASCE, Cornell University, Ithaca, New York, June 18-21, 1990; edited by Philip C. Lambe and Lawrence A. Hansen, New York, N.Y.: ASCE, 1990, 645-659

Y. Kanazawa; K Ikeda; O. Murata; M. Tateyama; F. Tatsuoka, Geosynthetic-reinforced soil retaining walls for reconstructing railway embankment at Amagasaki, Recent case histories of permanent geosynthetic-reinforced soil retaining walls / edited by Fumio Tatsuoka, Dov Leshchinsky, Rotterdam; Brookfield, VT: A.A. Balkema, c1994, 233-242 
Minhaj Kirmani, Steve Highfill, Jimmy Xu, Precast prestressed Slurry Wall for Pilot House Project, Design and construction of earth retaining systems: proceedings of sessions of Geo-Congress 98, October 18-21, 1998, Boston, Massachusetts / sponsored by the Earth Retaining Structures Committee of the Geo-Institute of the American Society of Civil Engineers; edited by Richard J. Finno ... [et al.], Reston, Va.: American Society of Civil Engineers, c1998, 82-89

R. M. Koerner, Designing with geosynthetics, Upper Saddle River, NJ: Prentice Hall, 1998

A. Kovacs, Designers/Contractors Email Survey, ARSEE Engineers, Project references: 00109, 7906, 8576, 91102, 97188, 87101 and 94127

Y. Lacroix, M. Esrig, U. Luscher, Design, construction and performance of cellular cofferdams, ASCE Specialty Conference on Lateral Stresses in the Ground and Design of Earth-Retaining Structures, Cornell University, New York, American Society of Civil Engineers, 1970

T. William Lambe and Robert V. Whitman, Soil Mechanics, John Wiley and Sons, New York, 1969

James R. Lambrechts, Paul A. Roy \& Eric J. Wishart, Design Conditions and Analysis Methods for Soil-Cement Buttresses in Fort Point Channel, Design and construction of earth retaining systems: proceedings of sessions of Geo-Congress 98, October 18-21, 1998, Boston, Massachusetts / sponsored by the Earth Retaining Structures Committee of the Geo-Institute of the American Society of Civil Engineers; edited by Richard J. Finno ... [et al.], Reston, Va.: American Society of Civil Engineers, c1998, 153-174

M. Long, Database for retaining wall and ground movements due to deep excavations, Journal of geotechnical engineering, Vol. 127, No. 3, March, 200, ASCE, 2001, 203-224

A. J. McGinn; T. D. O'Rourke, Case Study of Excavation Base Stability in Deep Marine Clay, Performance confirmation of constructed geotechnical facilities: proceedings of sessions of ASCE Specialty Conference on Performance Confirmation of Constructed Geotechnical Facilities: April 9-12, 2000, Amherst, Massachusetts / sponsored by the Geo-Institute of the American Society of Civil Engineers; edited by Alan J. Lutenegger, Don J. DeGroot, Reston, Va., Geo-Institute, ASCE, c2000, 481-495

Microsoft Access 2000 (9.0.2720), Microsoft Access Help. Microsoft Corporation, 1999

G. Munfakh, Innovative earth retaining structures: Selection, design and performance, Design and performance of earth retaining structures: proceedings of a conference / sponsored by the Geotechnical Engineering Division of the American Society of Civil Engineers in cooperation with the Ithaca Section, ASCE, Cornell University, Ithaca, New York, June 18-21, 1990; edited by Philip C. Lambe and Lawrence A. Hansen, New York, N.Y.: ASCE, 1990, 85-118 
Z. C. Moh; T. F. Song, Performance of Diaphragm Walls in Deep Foundation Excavations, International Conference on Case Histories in Geotechnical Engineering, May 6-11, 1984 / editor, Shamsher Prakash. Vol. 3., Rolla, Mo.: University of MissouriRolla, [1984], 1335-1343

Mark N. Obergfell, Construction and performance of a permanent earth anchor (tieback) system for the Stanford Linear Collider, Prediction and Performance in Geotechnical Engineering, Rotterdam: Boston: A.A. Balkema, 1987, 295-301

Richard O'Connor, Designers/Contractors Email Survey, Reid, Quebec, Allison \& Wilcox Corporation

J. Oliphant, The outline design of earth retaining walls, Ground Engineering, Brentwood, Essex, Foundation Publications, September 1997, 53-58

Phillip Ooi; Michael Walker; Hans van den Elsen; Phillip Rice, SPTC Wall With a Large Unbraced Length, Performance confirmation of constructed geotechnical facilities: proceedings of sessions of ASCE Specialty Conference on Performance Confirmation of Constructed Geotechnical Facilities: April 9-12, 2000, Amherst, Massachusetts / sponsored by the Geo-Institute of the American Society of Civil Engineers; edited by Alan J. Lutenegger, Don J. DeGroot, Reston, Va., Geo-Institute, ASCE, c2000, 516-530

Tolga Oral and Thomas C. Sheahan, The use of Soil Nails in Soft Clays, Design and construction of earth retaining systems: proceedings of sessions of Geo-Congress 98, October 18-21, 1998, Boston, Massachusetts / sponsored by the Earth Retaining Structures Committee of the Geo-Institute of the American Society of Civil Engineers; edited by Richard J. Finno ... [et al.], Reston, Va.: American Society of Civil Engineers, c1998, 26-40

T. D. O'Rourke; C. J. F. P. Jones, Overview of Earth Retaining Systems: 1970 - 1990, Design and performance of earth retaining structures: proceedings of a conference / sponsored by the Geotechnical Engineering Division of the American Society of Civil Engineers in cooperation with the Ithaca Section, ASCE, Cornell University, Ithaca, New York, June 18-21, 1990; edited by Philip C. Lambe and Lawrence A. Hansen, New York, N.Y.: ASCE, c1990, 22-51

T. D. O'Rourke; A. J. McGinn; J. Dewsnap; and H. E. Stewart, Case History of an Excavation stabilized by Deep Mixing Methods, Design and construction of earth retaining systems: proceedings of sessions of Geo-Congress 98, October 18-21, 1998, Boston, Massachusetts / sponsored by the Earth Retaining Structures Committee of the Geo-Institute of the American Society of Civil Engineers; edited by Richard J. Finno ... [et al.], Reston, Va.: American Society of Civil Engineers, c1998, 41-61

Gregory Pankow, INDOT Database, Indiana Department of Transportation, Project references: R-23364, R-22774-B, R-23007-A, R-23640-A, R-24432-A, and B-24293-A 
R. B. Peck, Deep excavation and Tunneling in Soft Ground, Proceedings, Seventh International Conference on Soil Mechanics and Foundation Engineering, Mexico City, State-of-the-art Volume, 1969

R. B. Peck, W. E. Hanson, and T. H. Thornburn, Foundation Engineering, 2nd Edition, John Wiley and Sons, New York, 1974

C. Plumelle; F. Shlosser; P. Delage; G. Knochenmus, French national research project on soil nailing: Clouterre, Design and performance of earth retaining structures: proceedings of a conference / sponsored by the Geotechnical Engineering Division of the American Society of Civil Engineers in cooperation with the Ithaca Section, ASCE, Cornell University, Ithaca, New York, June 18-21, 1990; edited by Philip C. Lambe and Lawrence A. Hansen, New York, N.Y.: ASCE, c1990, 661-675

John Reinfurt; Thomas C. Anderson; Paul Reitz; Tony Licari, Temporary Shoring Support Systems in an Urban Environment, Serviceability of earth retaining structures: proceedings of sessions sponsored by the Geotechnical Engineering Division of the American Society of Civil Engineers in conjunction with the ASCE National Convention in Atlanta, Georgia, October 9-13, 1994 / edited by Richard J. Finno, New York, N.Y.: ASCE, c1994, 24-42

Harry Schnabel, Design - Build Walls on Davidson Freeway Save Millions, Design and construction of earth retaining systems: proceedings of sessions of Geo-Congress 98, October 18-21, 1998, Boston, Massachusetts / sponsored by the Earth Retaining Structures Committee of the Geo-Institute of the American Society of Civil Engineers; edited by Richard J. Finno ... [et al.], Reston, Va.: American Society of Civil Engineers, c1998, 137-152

I. Smith, L. Kontoulis, A web-based knowledge-based system to assist decision making in the selection of earth retaining walls, First international conference on new information technologies for decision making in Civil Engineering, Montreal, Canada, October 11-13, $1998,625-632$

I. Smith, A. Oliver, J. Oliphant, WallAid: A knowledge-based system for the selection of earth retaining walls, Proceedings: 11th International Conference on Industrial and Engineering Applications of Artificial Intelligence and Expert Systems, IEA-98-AIE, Benicàssim, Castellón, Spain, June 1-4, 1998 / Edited by José Mira, Angel Pasqual del Pobil, Moonis Ali, New York: Springer, 1998, 888-895

Alan T. Stadler, Performance of Geogrid-Reinforced Retaining Walls at the South Carolina State Ports Authority's Wando Terminal, Performance confirmation of constructed geotechnical facilities: proceedings of sessions of ASCE Specialty Conference on Performance Confirmation of Constructed Geotechnical Facilities: April 9-12, 2000, Amherst, Massachusetts / sponsored by the Geo-Institute of the American Society of Civil Engineers; edited by Alan J. Lutenegger, Don J. DeGroot, Reston, Va., Geo-Institute, ASCE, c2000, 531-543 
Manfred F. Stocker; Georg Riedinger, The Bearing Behavior of Nailed Retaining Structures, Design and performance of earth retaining structures: proceedings of a conference / sponsored by the Geotechnical Engineering Division of the American Society of Civil Engineers in cooperation with the Ithaca Section, ASCE, Cornell University, Ithaca, New York, June 18-21, 1990; edited by Philip C. Lambe and Lawrence A. Hansen, New York, N.Y.: ASCE, c1990, 612-628

M. Tateyama; O. Murata; K. Watanabe; F. Tatsuoka, Geosynthetic-reinforced retaining walls for bullet train yard in Nagoya, Recent case histories of permanent geosyntheticreinforced soil retaining walls / edited by Fumio Tatsuoka, Dov Leshchinsky, Rotterdam; Brookfield, VT: A.A. Balkema, c1994, 141

J. Taylor; W. Galbraith; G. Richters; J. Baka; C. Chang, Construction of a Cofferdam Pressure Relief System, Serviceability of earth retaining structures: proceedings of sessions sponsored by the Geotechnical Engineering Division of the American Society of Civil Engineers in conjunction with the ASCE National Convention in Atlanta, Georgia, October 9-13, 1994 / edited by Richard J. Finno, New York, N.Y.: ASCE, c1994, 93-111

P. Tedd; B. M. Chard; J. A. Charles; I. F. Symmons, Behavior of a propped embedded retaining wall in stiff clay at Bell Common, Propped and cantilevered rigid walls, London: Telford, 1986, 21-40

Karl Terzaghi and Ralph B. Peck, Soil Mechanics in Engineering Practice, 2nd edition, John Wiley and Sons, New York, 1967. The first edition was published in 1948

Steven Thompson, A. M. ASCE; Ian Miller, Design, construction and performance of a soil nailed wall in Seattle Washington, Design and performance of earth retaining structures: proceedings of a conference / sponsored by the Geotechnical Engineering Division of the American Society of Civil Engineers in cooperation with the Ithaca Section, ASCE, Cornell University, Ithaca, New York, June 18-21, 1990; edited by Philip C. Lambe and Lawrence A. Hansen, New York, N.Y.: ASCE, c1990, 629-643

G. L. Tysinger, Slide Stabilization 4th Rocky Fill, Clinchfield RR, Application of walls to landslide control problems: proceedings of two sessions / sponsored by the Committee on Earth Retaining Structures of the Geotechnical Engineering Division of the American Society of Civil Engineers at the ASCE National Convention, Las Vegas, Nevada, April 29, 1982; R.B. Reeves, editor, New York, N.Y.: ASCE, c1982, 93-107

H. Vidal, The development and future of Reinforced Earth, Symposium on Earth Reinforcement: proceedings of a symposium / sponsored by the Committee on Placement and Improvement of Soils of the Geotechnical Engineering Division of the American Society of Civil Engineers at the ASCE annual convention, Pittsburgh, Pennsylvania, April 27, 1978, New York: The Society, 1979, 1-61

Y. Z. Wang, Distribution of earth pressure on a retaining wall, Géotechnique 50, No. 1, London, Institution of Civil Engineers, 2000, 83-88 
D. E. Weatherby and P. J. Nicholson, Tiebacks used for landslide stabilization, Application of walls to landslide control problems: proceedings of two sessions / sponsored by the Committee on Earth Retaining Structures of the Geotechnical Engineering Division of the American Society of Civil Engineers at the ASCE National Convention, Las Vegas, Nevada, April 29, 1982; R.B. Reeves, editor, New York, N.Y.: ASCE, 1982, 44-60

L. A. Wood and A. J. Perrin, Observations of a strutted diaphragm wall in London clay: a preliminary assessment, Propped and cantilevered rigid walls, London: Telford, 1986, 7187

Jonathan T. H. Wu; Robert K. Barret; Nelson N. S. Chou, Developing cost-effective GRS walls: Recent efforts in Colorado, USA, Recent case histories of permanent geosyntheticreinforced soil retaining walls / edited by Fumio Tatsuoka, Dov Leshchinsky, Rotterdam; Brookfield, VT: A.A. Balkema, c1994, 166-170

Tzong H. Wu; Nelson N. S. Chou, Performance of twin-tee test wall for Interstate Highway 70 near Glenwood Canyon, Colorado, Prediction and Performance in Geotechnical Engineering, Rotterdam: Boston: A.A. Balkema, 1987, 303-309

E. J. Zeigler; J. L. Wirth; J. T. Miller, Slurry Trench Wall Replaces Structure Underpinning, International Conference on Case Histories in Geotechnical Engineering, May 6-11, 1984 / editor, Shamsher Prakash. Vol. 3, Rolla, Mo.: University of MissouriRolla, [1984], 1287-1296 